DOE/EIA-0205(96)

Distribution Category UC-950

\title{
Energy Information Directory 1996
}

\author{
January 1997
}

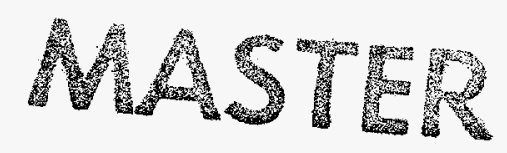

Energy Information Administration National Energy Information Center

U.S. Department of Energy

Washington, DC 20585

This report was prepared by the Enargy Information Administration, the independent statistical and analytical agency within the U.S. Department of Energy. The information contained herein should not be construed as advocating or necessarily reflecting any policy position of the Department of Energy or of any other organization. 


\section{Preface}

The National Energy Information Center (NEIC), as part of its mission, provides energy information and referral assistance to Federal, State, and local governments, the academic community, business and industrial organizations, and the general public. The two principal functions related to this task are: 1) operating a general access telephone line, and 2) responding to energy-related correspondence addressed to the Energy Information Administration (EIA). The Energy Information Directory was developed to assist the NEIC staff, as well as other Department of Energy (DOE) staff, in directing inquiries to the proper offices within DOE, other Federal agencies, or energy-related trade associations.

The Directory lists most Government offices and trade associations that are involved in energy matters.
It does not include those DOE offices which do not deal with the public or public information. For the purposes of this publication, each entry has been given a numeric identification symbol. The index found in the back of this publication uses these identification numbers to refer the reader to relevant entries.

The Directory is published annually, with each issue superseding the previous edition. Questions concerning the content of an entry should be directed to Leola Withrow at $(202) 586-1171$. General information can be obtained by contacting NEIC at (202) 586-8800. Copies of the Directory are free and can be obtained from NEIC at the following address:

\author{
National Energy Information Center \\ Energy Information Administration \\ U.S. Department of Energy \\ El-231, Forrestal Building \\ Washington, DC 20585 \\ (202) $586-8800$
}

TTY: For people who are deaf

or hard of hearing--(202) 586-1181

Additional information about this and other EIA products is available on the Internet. See the inside cover for the Internet address. 


\section{DISCLAIMER}

Portions of this document may be illegible in electronic image products. Images are produced from the best available original document. 


\section{DISCLAIMER}

This report was prepared as an account of work sponsored by an agency of the United States Government. Neither the United States Government nor any agency thereof, nor any of their employees, make any warranty, express or implied, or assumes any legal liability or responsibility for the accuracy, completeness, or usefulness of any information, apparatus, product, or process disclosed, or represents that its use would not infringe privately owned rights. Reference herein to any specific commercial product, process, or service by trade name, trademark, manufacturer, or otherwise does not necessarily constitute or imply its endorsement, recommendation, or favoring by the United States Government or any agency thereof. The views and opinions of authors expressed herein do not necessarily state or reflect those of the United States Government or any agency thereof. 


\section{CONTENTS}

Information Centers

Energy Efficiency and Renewable Energy Clearing House (EREC) $\ldots \ldots \ldots \ldots \ldots \ldots$

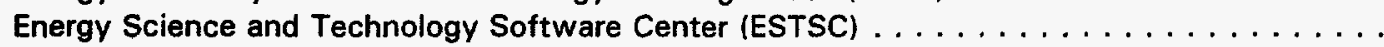

National Energy Information Center (NEIC) . . . . . . . . . . . . . . . . . .

National Institute for Petroleum and Energy Research (NIPER) $\ldots \ldots \ldots \ldots \ldots \ldots \ldots$

Office of Scientific and Technical Information (OSTI) $\ldots \ldots \ldots \ldots \ldots \ldots \ldots$

Page

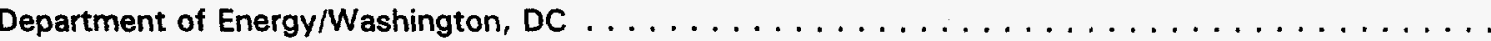

Departmental Advisory Committees . . . . . . . . . . . . . . . . . . . .

American Statistical Association Committee on Energy Statistics (ASA) . . . . . .

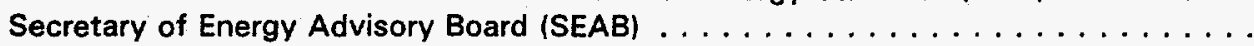

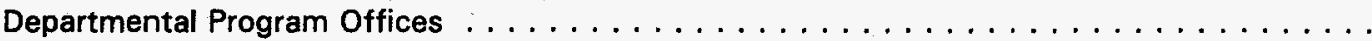

Office of the Assistant Secretary for Congressional, Public and $\ldots \ldots \ldots \ldots \ldots$

Intergovernmental Affairs $(C P) \ldots \ldots \ldots \ldots \ldots$

Office of the Deputy Assistant Secretary for Communications . . . . . . . . . . . .

Office of the Deputy Assistant Secretary for House Liaison . . . . . . . . . . . . .

Office of the Deputy Assistant Secretary for Senate Liaison . . . . . . . . . . . . . .

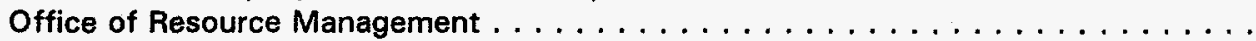

Office of Research and Editorial Services . . . . . . . . . . . . . . .

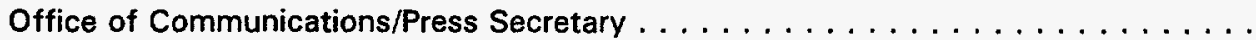

Office of Communications/Internal Communications $\ldots \ldots \ldots \ldots \ldots \ldots$

Office of the Deputy Assistant Secretary for Intergovernmental and External Affairs .

Office of Congressional Liaison $\ldots \ldots \ldots \ldots \ldots \ldots \ldots \ldots \ldots \ldots \ldots$

Office of the Assistant Secretary for Defense Programs (DP) $\ldots \ldots \ldots \ldots \ldots$

Office of the Deputy Assistant Secretary for Research and Development . . . . . . .

Office of Research, Development and Testing Facilities . . . . . . . . . . . .

Office of Defense Programs Laboratories and Reimbursable Programs . . . . . . . .

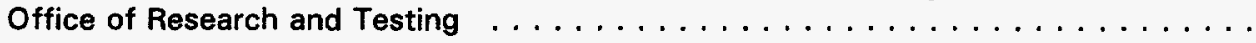

Office of Development and Technology Transfer $\ldots \ldots \ldots \ldots \ldots \ldots \ldots$

Office of Inertial Fusion and Ignition Facility (IF) Project $\ldots \ldots \ldots \ldots \ldots \ldots$

Office of the Deputy Assistant Secretary for Military Application

and Stockpile Management . . . . . . . . . . . . . . . . . .

Office of the Associate Deputy Assistant Secretary for Military Application

and Stockpile Management $\ldots \ldots \ldots \ldots \ldots \ldots \ldots \ldots$

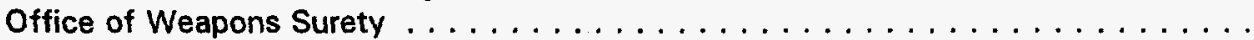

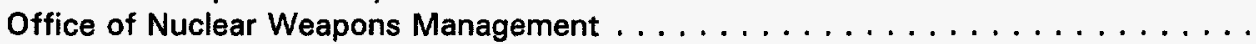

Office of Emergency Response . . . . . . . . . . . . . . . . . .

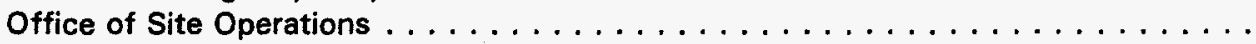

Office of Advanced Design and Production Technologies $\ldots \ldots \ldots \ldots \ldots \ldots$

Office of the Deputy Assistant Secretary for Program Support . . . . . . . . . . . . .

Office of the Deputy Assistant Secretary for Program Analysis

and Financial Management $\ldots \ldots \ldots \ldots \ldots \ldots \ldots \ldots$

Office of the Associate Deputy Assistant Secretary for Human and

Administrative Resources $\ldots \ldots \ldots \ldots \ldots \ldots \ldots$

Office of the Deputy Assistant Secretary for Technical and Environmental Support . .

Office of the Deputy Assistant Secretary for Strategic Computing and

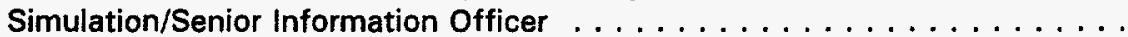

Office of Strategic Computing and Modeling $\ldots \ldots \ldots \ldots \ldots \ldots \ldots$

Office of Stockpile Computation and Modeling $\ldots \ldots \ldots \ldots \ldots \ldots \ldots$

Office of Defense Programs Information Architecture $\ldots \ldots \ldots \ldots \ldots \ldots$

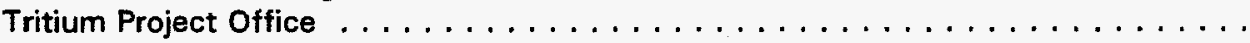

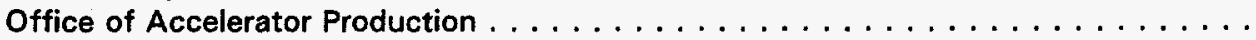

Office of Commercial Light Water Reactor Production $\ldots \ldots \ldots \ldots \ldots \ldots \ldots$

Office of Economic Impact and Diversity (ED) $\ldots \ldots \ldots \ldots \ldots$

Office of Minority Economic Impact $\ldots \ldots \ldots \ldots \ldots \ldots \ldots \ldots \ldots$

Office of Small and Disadvantaged Business Utilization $\ldots \ldots \ldots \ldots \ldots \ldots \ldots$

Office of the Assistant Secretary for Energy Efficiency and Renewable Energy (EE) . 
Office of the Deputy Assistant Secretary for Utility Technologies . . . . . . . . . Office of Photovoltaic and Wind Technologies $\ldots \ldots \ldots \ldots \ldots \ldots$

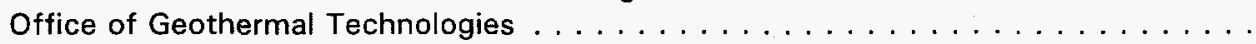
Office of Solar Thermal, Biomass Power and Hydrogen Technologies . . . . . . . .

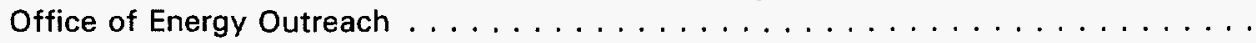
Office of the Deputy Assistant Secretary for Industrial Technologies . . . . . . . . .

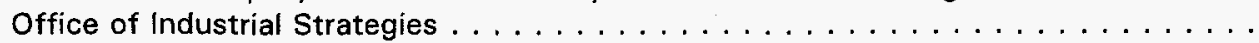

Office of Industrial Process Systems $\ldots \ldots \ldots \ldots \ldots \ldots \ldots \ldots \ldots$

Office of Industrial Crosscut Technologies $\ldots \ldots \ldots \ldots \ldots \ldots \ldots \ldots$

Office of Technology Access . . . . . . . . . . . . . . . . . . . . .

Office of the Deputy Assistant Secretary for Transportation Technologies . . . . . . .

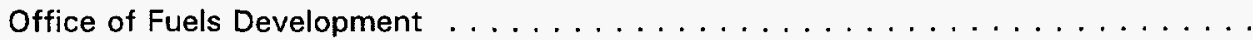

Office of Advanced Automotive Technologies $\ldots \ldots \ldots \ldots \ldots \ldots \ldots$

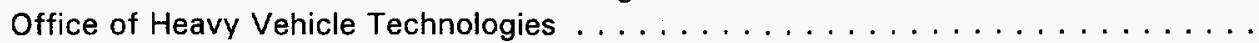

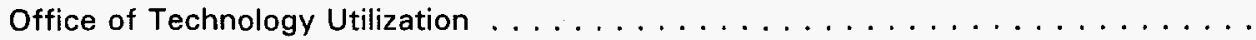

Office of the Deputy Assistant Secretary for Building Technology, State

and Community Programs $\ldots \ldots \ldots \ldots \ldots \ldots \ldots \ldots$

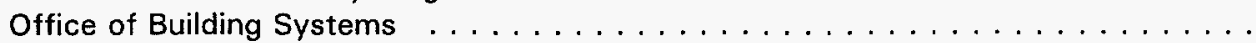

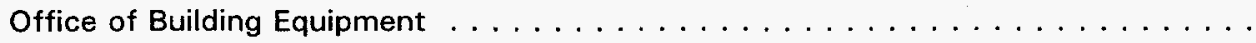

Office of Codes and Standards $\ldots \ldots \ldots \ldots \ldots \ldots \ldots \ldots \ldots \ldots$

Office of State and Community Programs $\ldots \ldots \ldots \ldots \ldots \ldots \ldots \ldots$

Office of Management and Operations $\ldots \ldots \ldots \ldots \ldots \ldots \ldots \ldots$

Office of Budget Planning and Customer Service $\ldots \ldots \ldots \ldots \ldots \ldots$

Office of Federal Energy Management Programs . . . . . . . . . . . . . . .

Golden Field Office . . . . . . . . . . . . . . . . . . . . .

Office of the Assistant Secretary for Environment, Safety and Health $(E H) \ldots \ldots$. . .

Office of the Deputy Assistant Secretary for Oversight $\ldots \ldots \ldots \ldots \ldots \ldots$

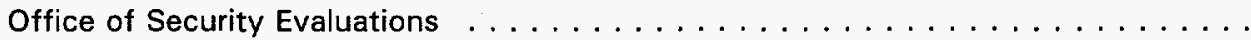

Office of Environment, Safety and Health Evaluations $\ldots \ldots \ldots \ldots \ldots \ldots \ldots$

Office of Oversight Analysis and Planning Support $\ldots \ldots \ldots \ldots \ldots \ldots$

Office of Environment, Safety and Health Residents . . . . . . . . . . . . .

Office of the Deputy Assistant Secretary for Nuclear and Facility Safety . . . . . . . .

Office of Nuclear Safety Policy and Standards $\ldots \ldots \ldots \ldots \ldots \ldots \ldots$

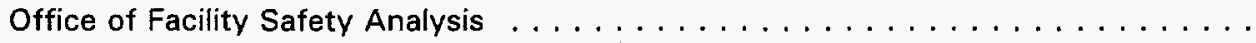

Office of Operating Experience Analysis $\ldots \ldots \ldots \ldots \ldots \ldots \ldots \ldots$

Office of Engineering Assistance and Site Interface $\ldots \ldots \ldots \ldots \ldots \ldots$

Office of the Deputy Assistant Secretary for Environment . . . . . . . . . . .

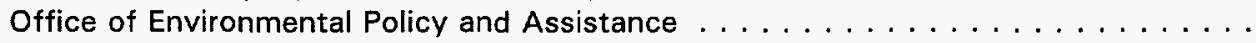

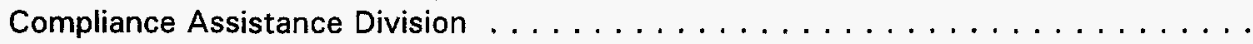

Air, Water, and Radiation Division $\ldots \ldots \ldots \ldots \ldots \ldots \ldots \ldots \ldots$

Resource Conservation and Recovery Act/Comprehensive Environmental

Response Compensation and Liability Act (RCRA/CERCLA) Division . . . . .

Office of National Energy Policy Act (NEPA) Policy and Assistance . . . . . . . . . . .

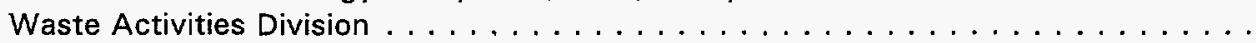

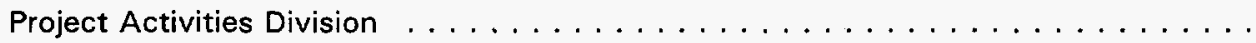

Office of the Deputy Assistant Secretary for Worker Health and Safety . . . . . . . .

Office of Occupational Safety and Health Policy . . . . . . . . . . . . .

Office of Worker Protection Programs and Hazards Management . . . . . . . . . .

Office of Field Support $\ldots \ldots \ldots \ldots \ldots \ldots \ldots \ldots \ldots \ldots \ldots$

Office of the Deputy Assistant Secretary for Health Studies . . . . . . . . . . . . . .

Office of Occupational Medicine and Medical Surveillance . . . . . . . . . . .

Office of Epidemiologic Studies $\ldots \ldots \ldots \ldots \ldots \ldots \ldots \ldots \ldots \ldots \ldots$

Office of International Health Programs . . . . . . . . . . . . . . . .

Office of the Deputy Assistant Secretary for Planning and Administration . . . . . . .

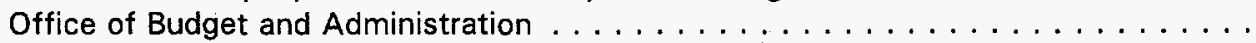

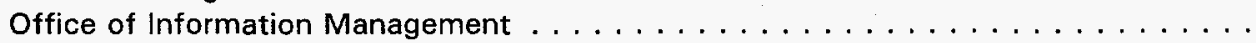

Office of Business Performance Systems $\ldots \ldots \ldots \ldots \ldots \ldots \ldots \ldots$

Office of Technical Training and Professional Development $\ldots \ldots \ldots \ldots \ldots$

Office of Human Radiation Experiments . . . . . . . . . . . . . . . .

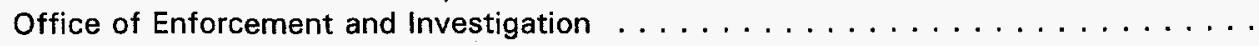

Energy Information Administration 


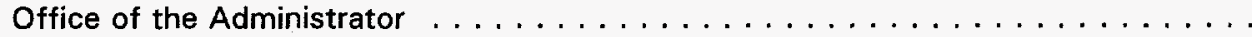

Office of Oil and Gas $\ldots \ldots \ldots \ldots \ldots \ldots \ldots \ldots \ldots \ldots \ldots$

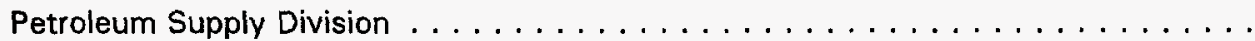

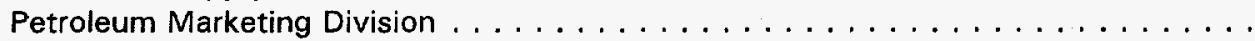

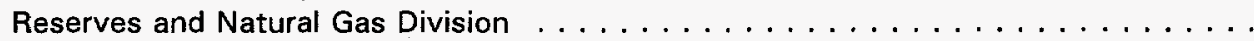

Office of Coal, Nuclear, Electric and Alternate Fuels $\ldots \ldots \ldots \ldots \ldots \ldots$

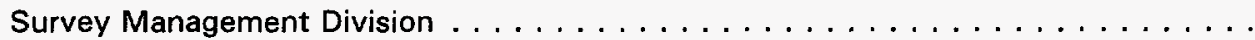

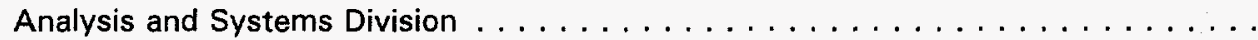

Office of Energy Markets and End Use $\ldots \ldots \ldots \ldots \ldots \ldots \ldots \ldots$

Energy Markets and Contingency Information Division . . . . . . . . . . . .

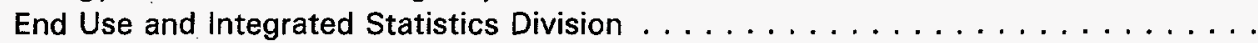

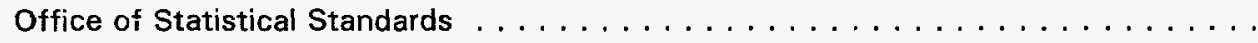

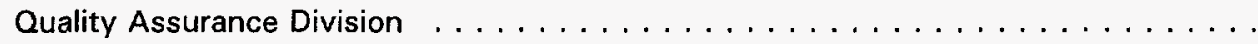

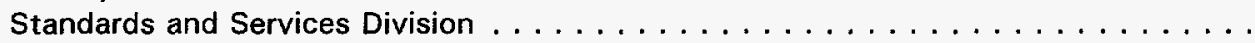

Office of Integrated Analysis and Forecasting $\ldots \ldots \ldots \ldots \ldots \ldots$

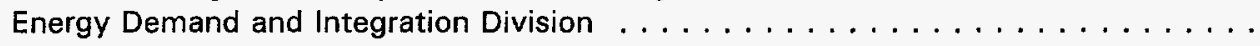

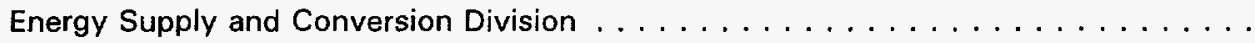

Office of the Assistant Secretary for Environmental Management (EM) . . . . . . . .

Office of the Deputy Assistant Secretary for Waste Management . . . . . . . . . . .

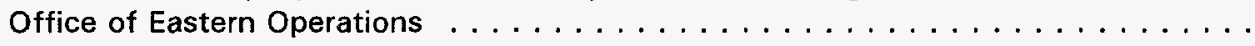

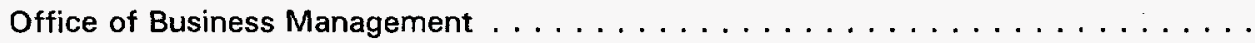

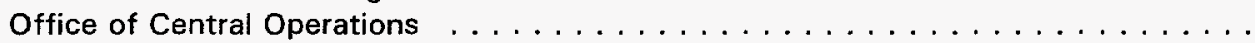

Office of Planning and Analysis $\ldots \ldots \ldots \ldots \ldots \ldots \ldots \ldots \ldots$

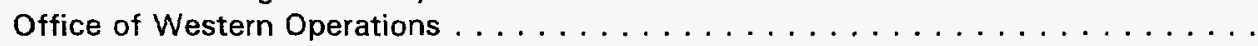

Office of Technical Services $\ldots \ldots \ldots \ldots \ldots \ldots \ldots \ldots \ldots \ldots$

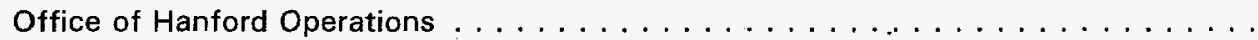

Office of the Deputy Assistant Secretary for Environmental Restoration . . . . . . .

Office of Eastern Area Programs . . . . . . . . . . . . . . . . . .

Office of Program Support, Environmental Restoration $\ldots \ldots \ldots \ldots \ldots \ldots$

Office of Northwestern Area Programs $\ldots \ldots \ldots \ldots \ldots \ldots \ldots \ldots$

Office of Southwestern Area Programs $\ldots \ldots \ldots \ldots \ldots \ldots \ldots \ldots \ldots$

Office of the Deputy Assistant Secretary for Science and Technology . . . . . . . . .

Office of Technology Systems $\ldots \ldots \ldots \ldots \ldots \ldots \ldots \ldots \ldots \ldots \ldots$

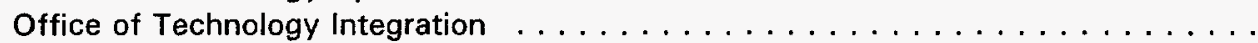

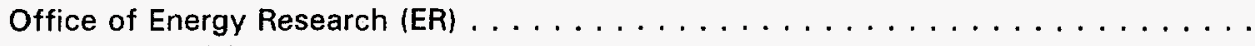

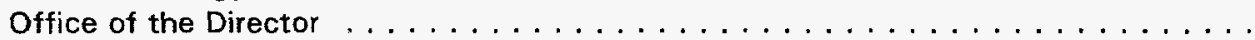

Office of Environment, Safety and Health Technical Support . . . . . . . . . . .

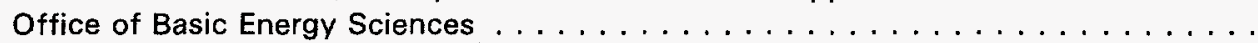

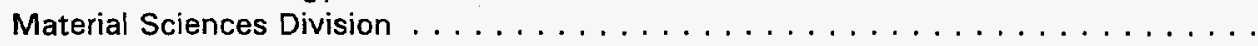

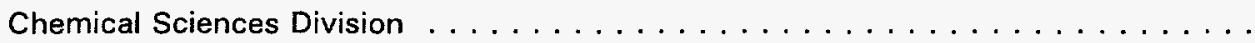

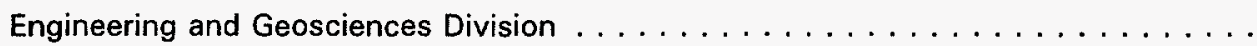

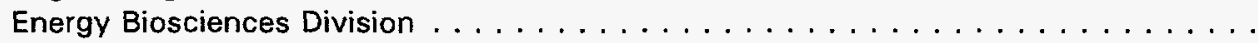

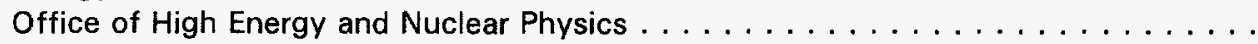

Office of Computational and Technology Research $\ldots \ldots \ldots \ldots \ldots \ldots$

Office of Fusion Energy Sciences $\ldots \ldots \ldots \ldots \ldots \ldots \ldots \ldots \ldots$

International Programs Staff

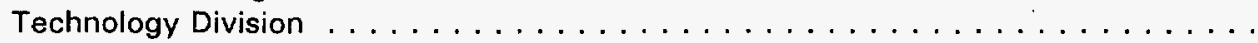

Science Division . . . . . . . . . . . . . . . . . . . . .

Office of Health and Environmental Research $\ldots \ldots \ldots \ldots \ldots \ldots \ldots$

Health Effects and Life Sciences Research Division . . . . . . . . . . . . . . .

Medical Applications and Biophysical Research Division . . . . . . . . . . . .

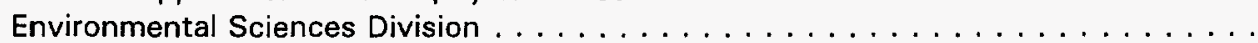

Office of the Assistant Secretary for Fossil Energy (FE) $\ldots \ldots \ldots \ldots \ldots \ldots$

Office of Coal and Power Systems $\ldots \ldots \ldots \ldots \ldots \ldots \ldots \ldots \ldots \ldots$

Office of Natural Gas and Petroleum Technologies $\ldots \ldots \ldots \ldots \ldots \ldots$

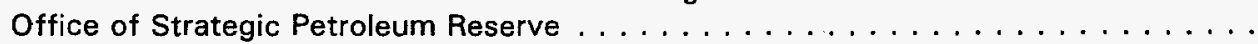

Office of Naval Petroleum and Oil Shale Reserves . . . . . . . . . . . . .

Office of Hearings and Appeals $(H G) \ldots \ldots \ldots \ldots \ldots \ldots \ldots \ldots$

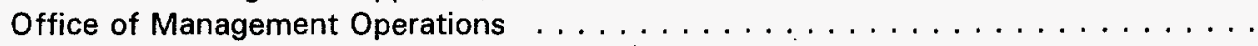

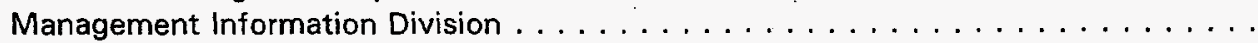

Docket and Publications Division 
Office of Legal Analysis $\ldots \ldots \ldots \ldots \ldots \ldots \ldots \ldots \ldots \ldots \ldots \ldots \ldots$

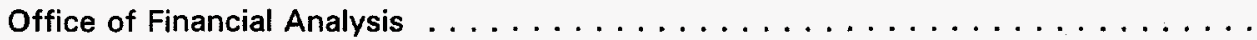

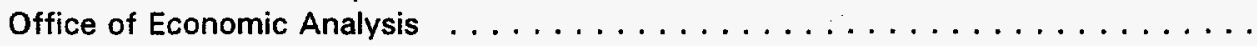

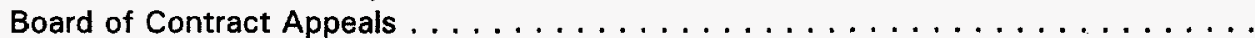

Office of Procurement, Assistance Management . . . . . . . . . . . . . .

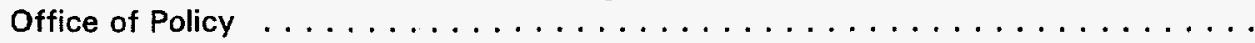

Office of Clearance and Support . . . . . . . . . . . . . . . . .

Office of Headquarters Procurement Operations $\ldots \ldots \ldots \ldots \ldots \ldots \ldots \ldots$

Office of the Executive Secretariat $\ldots \ldots \ldots \ldots \ldots \ldots \ldots \ldots \ldots \ldots$

Freedom of Information and Privacy Act Division $\ldots \ldots \ldots \ldots \ldots \ldots$

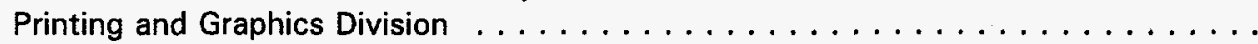

Office of Nuclear Energy, Science and Technology (NE) . . . . . . . . . . .

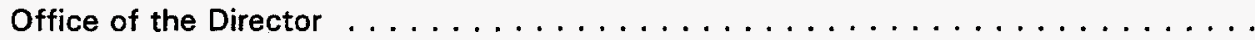

Office of Resource Management . . . . . . . . . . . . . . . . .

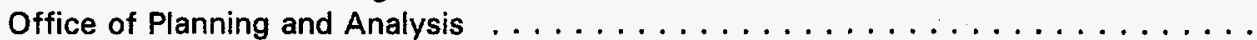

Office of International Nuclear Safety $\ldots \ldots \ldots \ldots \ldots \ldots \ldots \ldots$

Office of Facilities

Office of Engineering and Technology Development $\ldots \ldots \ldots \ldots \ldots \ldots$

Naval Reactors . . . . . . . . . . . . . . . . . . . . . . .

Office of Isotope Production and Distribution . . . . . . . . . . . . . .

Assistant Secretary for Policy and International Affairs (PO) . . . . . . . . . . . .

Office of Strategic Planning, Budget and Program Evaluation . . . . . . . . . . . . . .

Office of the Deputy Assistant Secretary for Materials-Asset Management . . . . . . and National Security Policy Analysis . . . . . . . . . . . . .

Office of National Security Analysis . . . . . . . . . . . . . . . . .

Office of Materials-Asset Management Analysis . . . . . . . . . . . . . .

Office of the Deputy Assistant Secretary for Energy, Environment and

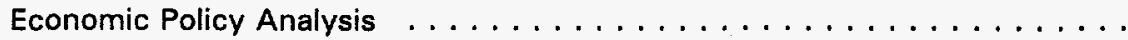

Office of Economic, Electricity and Natural Gas Analysis . . . . . . . . . . . . .

Office of Energy Efficiency, Alternative Fuels and Oil Analysis . . . . . . . . . . . .

Office of the Deputy Assistant Secretary for International Energy Policy,

Trade and Investment

Office of Policy Analysis, Trade and Investment for Europe,

New Independent States (NIS) and the Middle East . . . . . . . . . . . . .

Office of Policy Analysis, Trade and Investment for the Americas,

Asia Pacific and Africa

Office of the Deputy Assistant Secretary for Science and Technology

Policy and Cooperation

Office of Science and Technology Policy Analysis . . . . . . . . . . . . . . . .

Office of International Science and Technology Cooperation $\ldots \ldots \ldots \ldots \ldots$

Office of Civilian Radioactive Waste Management $(\mathrm{RW}) \ldots \ldots \ldots \ldots \ldots \ldots$

Office of Quality Assurance $\ldots \ldots \ldots \ldots \ldots \ldots \ldots \ldots \ldots \ldots \ldots$

Office of Human Resources and Administration $\ldots \ldots \ldots \ldots \ldots \ldots$

Yucca Mountain Site Characterization Office $\ldots \ldots \ldots \ldots \ldots \ldots \ldots$

Office of Program Management and Integration . . . . . . . . . . . . .

Office of Waste Acceptance, Storage and Transportation . . . . . . . . . . . .

Federal Energy Regulatory Commission (FERC) $\ldots \ldots \ldots \ldots \ldots \ldots \ldots$

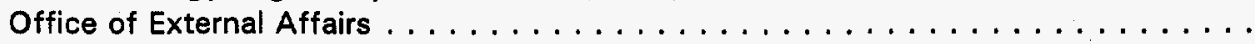

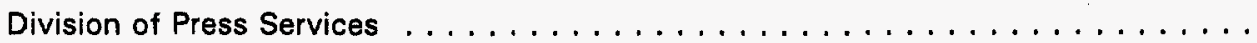

Division of Congressional, Intergovernmental and Public Affairs . . . . . . . . . .

Department of Energy Laboratories, Field Facilities, and Power Administrations . . . . . . . . . . . .

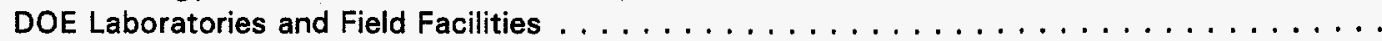

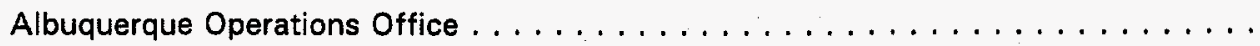

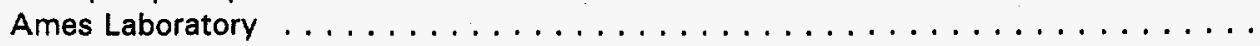

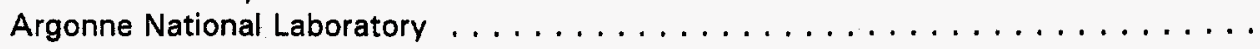

Bartlesville Project Office . . . . . . . . . . . . . . . . . . .

Battelle Pacific Northwest National Laboratory . . . . . . . . . . . . . . .

Brookhaven National Laboratory . . . . . . . . . . . . . . . . . .

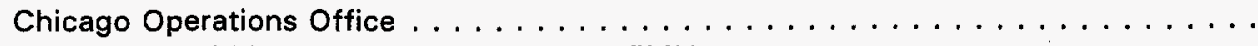

Environmental Measurements Laboratory (EML) $\ldots \ldots \ldots \ldots \ldots \ldots \ldots \ldots$

Fermi National Accelerator Laboratory . . . . . . . . . . . . . . . . . . 


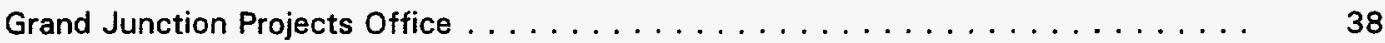

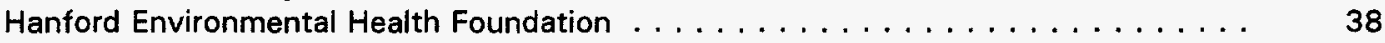

Idaho Operations Office $\ldots \ldots \ldots \ldots \ldots \ldots \ldots \ldots \ldots$

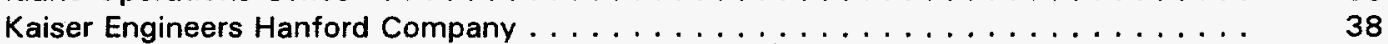

Lawrence Berkeley National Laboratory . . . . . . . . . . . . . . . . . . . . . . . . . . . . . . . . . . . . . . . .

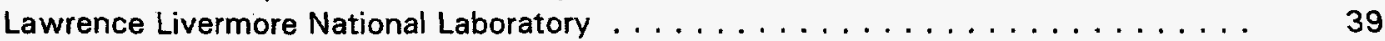

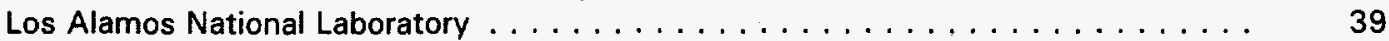

Morgantown Energy Technology Center (METC) . . . . . . . . . . . . . . . . . . . . . . . . . . . . . . . . . . . . . .

National Renewable Energy Laboratory (NREL) . . . . . . . . . . . . . . . . . . . . . . 39

Naval Petroleum and Oil Shale Reserves in Colorado, Utah, and

Wyoming, NOSR-1, NOSR-2, NOSR-3 ................ 39

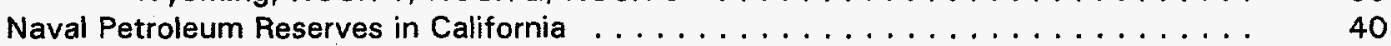

Nevada Operations Office . . . . . . . . . . . . . . . . . . . . . . . . . 40

Oakland Operations Office . . . . . . . . . . . . . . . . . . . . . . . 40

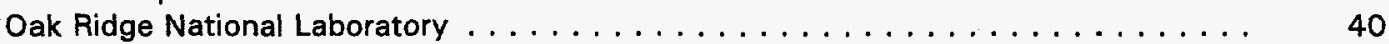

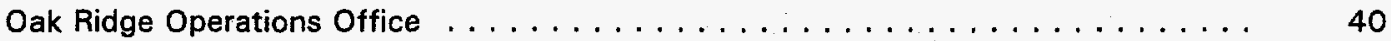

Pittsburgh Energy Technology Center . . . . . . . . . . . . . . . . . . . . 41

Pittsburgh Naval Reactors Office $\ldots \ldots \ldots \ldots \ldots \ldots \ldots \ldots \ldots \ldots$

Portsmouth Site Office . . . . . . . . . . . . . . . . . . . . . 41

Princeton Plasma Physics Laboratory (PPPL) . . . . . . . . . . . . . . . . . 41

Richland Operations Office $\ldots \ldots \ldots \ldots \ldots \ldots \ldots \ldots \ldots \ldots \ldots \ldots \ldots \ldots$

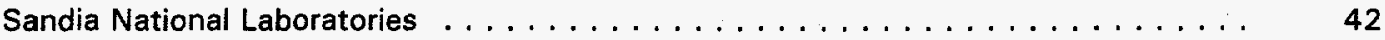

Savannah River Operations Office . . . . . . . . . . . . . . . . . . . . . . . . 42

Schenectady Naval Reactors Office (SNR) . . . . . . . . . . . . . . . . . . . 42

Stanford Linear Accelerator Center . . . . . . . . . . . . . . . . . . . . . . . . . . . . . . . . . . . . . . . .

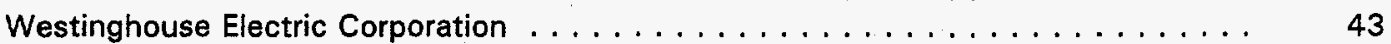

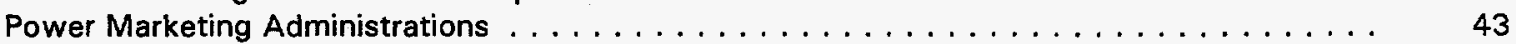

Alaska Power Administration . . . . . . . . . . . . . . . . . . . . 43

Bonneville Power Administration . . . . . . . . . . . . . . . . . . . . . . . . 43

Southeastern Power Administration $\ldots \ldots \ldots \ldots \ldots \ldots \ldots$

Southwestern Power Administration . . . . . . . . . . . . . . . . . 43

Western Area Power Administration $\ldots \ldots \ldots \ldots \ldots \ldots$

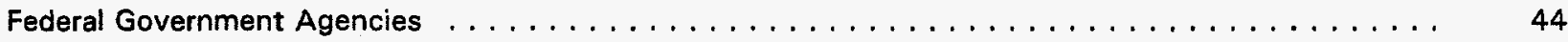

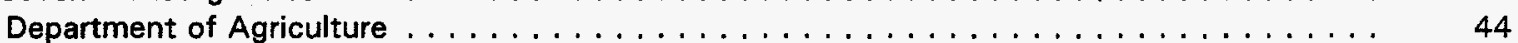

Economic Research Service . . . . . . . . . . . . . . . . . . . . . . . . . 44

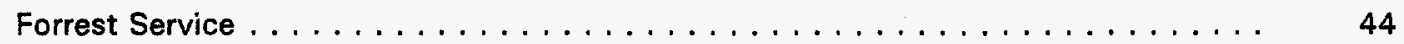

Rural Utilities Service . . . . . . . . . . . . . . . . . . . . . . . . . . . . . . . . 44

Department of Commerce $\ldots \ldots \ldots \ldots \ldots \ldots \ldots \ldots \ldots$

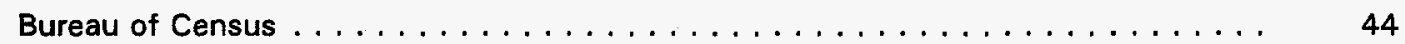

Bureau of Economic Analysis . . . . . . . . . . . . . . . . . . . . . . . . . 44

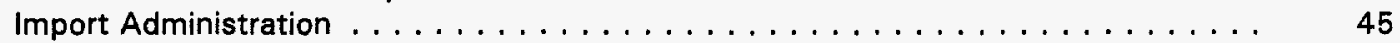

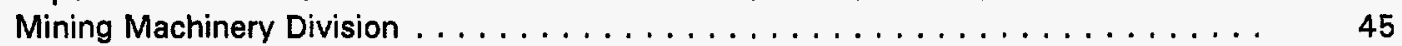

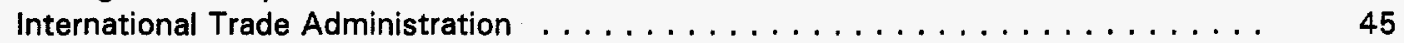

Office of Energy, Infrastructure, and Machinery . . . . . . . . . . . . . . . . . . 45

National Institute of Standards and Technology . . . . . . . . . . . . . . . . . 45

National Oceanic and Atmospheric Administration . . . . . . . . . . . . . . . . . . . . . . . . . . . . .

National Climatic Data Center . . . . . . . . . . . . . . . . . . . . . . . . . . . 45

National Technical Information Service (NTIS) $\ldots \ldots \ldots \ldots \ldots \ldots$

Department of Defense . . . . . . . . . . . . . . . . . . . . . . . . . . . . 46

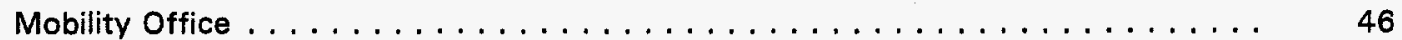

Facility Energy . . . . . . . . . . . . . . . . . . . . . . . . 46

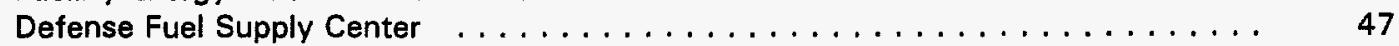

Department of Health and Human Services $\ldots \ldots \ldots \ldots \ldots \ldots$

Office of Community Services . . . . . . . . . . . . . . . . . . . . . . . 47

Department of Housing and Urban Development (HUD) $\ldots \ldots \ldots \ldots \ldots$

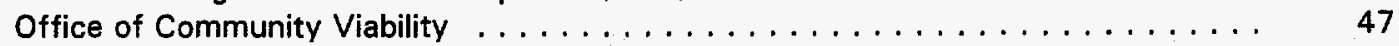

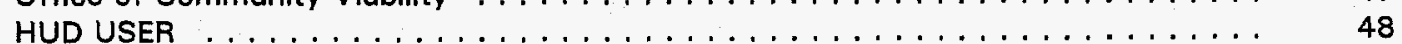

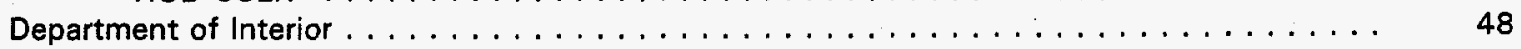

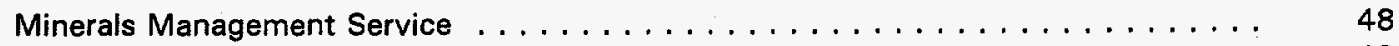

Office of Surface Mining Reclamation and Enforcement . . . . . . . . . . . . . 48

U.S. Geological Survey (USGS) . . . . . . . . . . . . . . . . . . . . . . . 48 
Department of Labor . . . . . . . . . . . . . . . . . . . . . . . . 49

Bureau of Labor Statistics $\ldots \ldots \ldots \ldots \ldots \ldots \ldots \ldots \ldots \ldots \ldots \ldots$

Division of Monthly Industry Employment Statistics . . . . . . . . . . . . . . . . . 49

Mine Safety and Health Administration (MSHA) . . . . . . . . . . . . . . . . 49

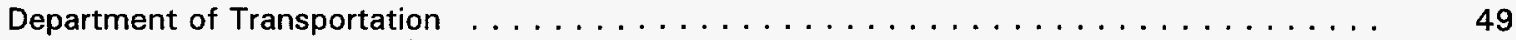

Office of Environment, Energy, and Safety $\ldots \ldots \ldots \ldots \ldots \ldots \ldots \ldots$

Office of Regulatory Affairs . . . . . . . . . . . . . . . . . . . . . 49

Federal Highway Administration . . . . . . . . . . . . . . . . . . . . . . . 49

National Highway Traffic Safety Administration . . . . . . . . . . . . . . . . . . . . . . 49

Research and Special Programs Administration . . . . . . . . . . . . . . 50

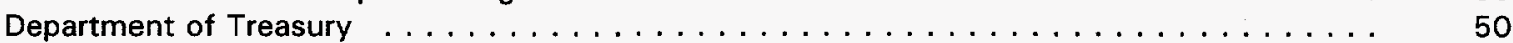

Bureau of Alcohol, Tobacco, and Firearms (ATF) $\ldots \ldots \ldots \ldots \ldots$

Federal Taxpayers Service Line . . . . . . . . . . . . . . . . . . . . 50

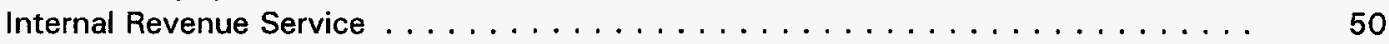

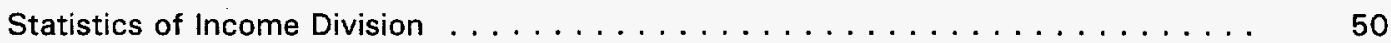

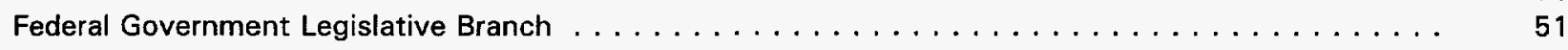

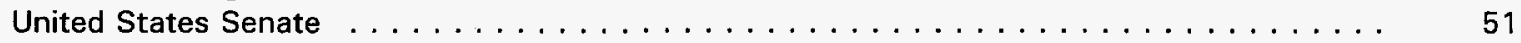

Committee on Energy and Natural Resources . . . . . . . . . . . . . . . 51

Subcommittee on Energy Research and Development ............... 51

Subcommittee on Public Lands, National Parks and Forests . . . . . . . . . . . 51

Subcommittee on Water and Power . . . . . . . . . . . . . . . . 51

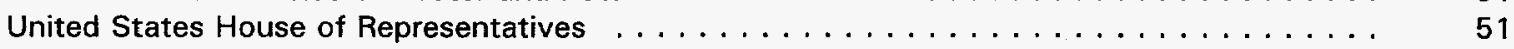

Committee on Commerce ......................... 51

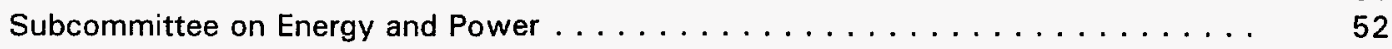

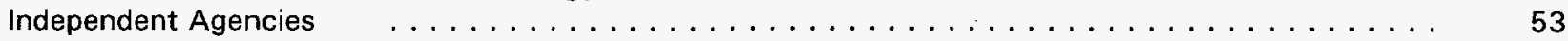

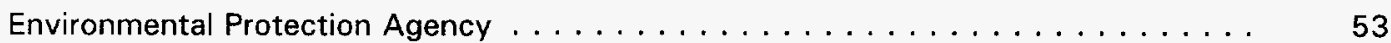

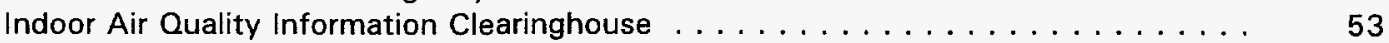

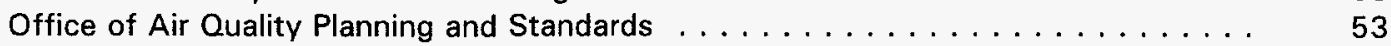

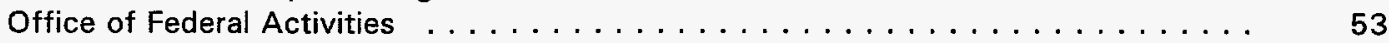

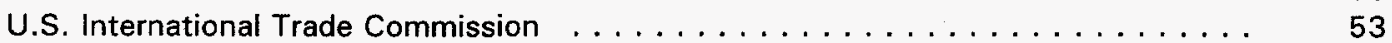

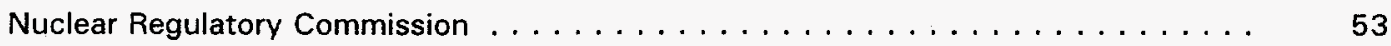

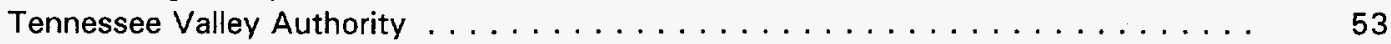

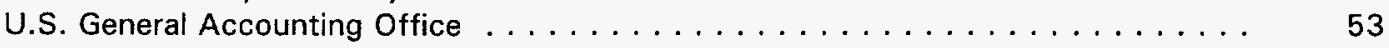

U.S. Government Printing Office . . . . . . . . . . . . . . . . . . . . . . . . . . . . 53

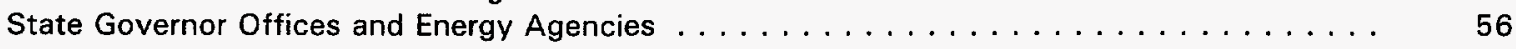

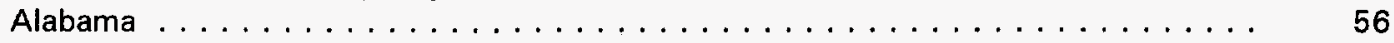

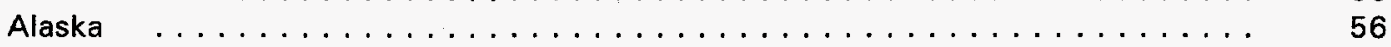

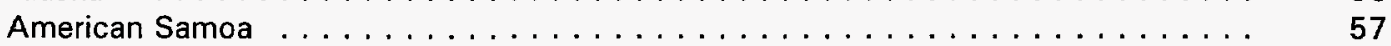

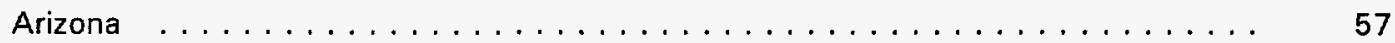

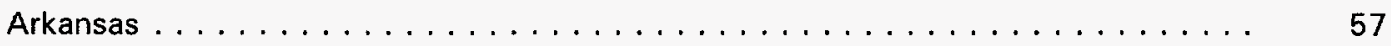

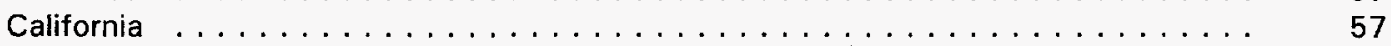

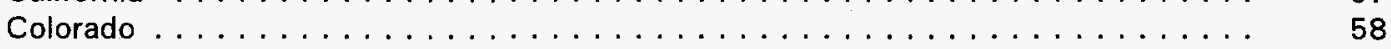

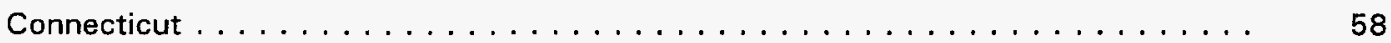

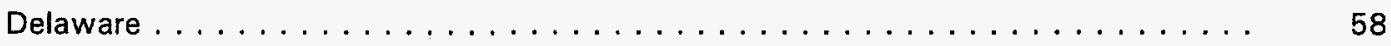

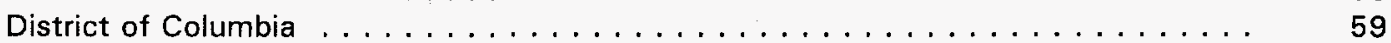

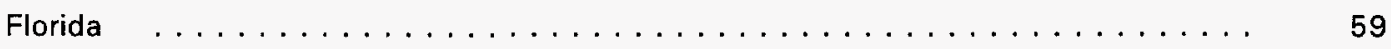

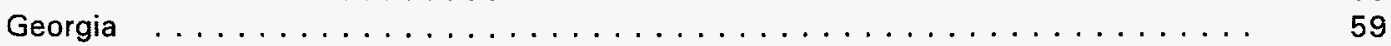

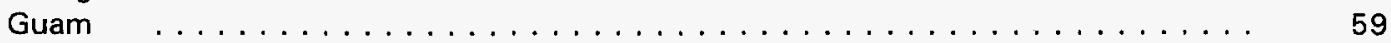

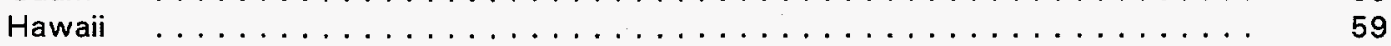

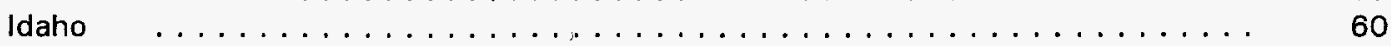

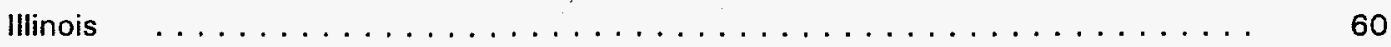

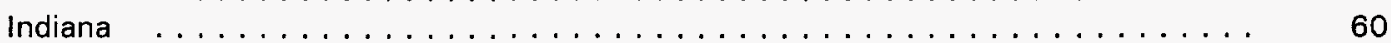

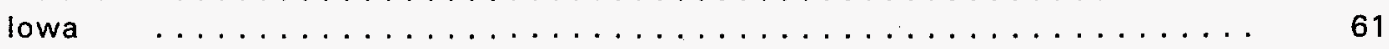

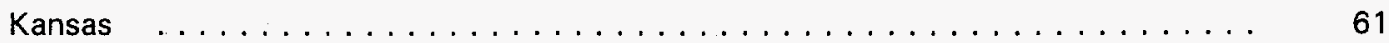

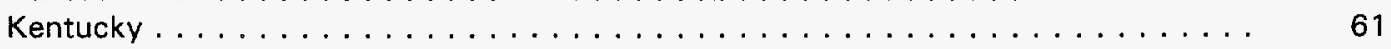

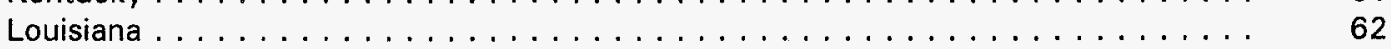

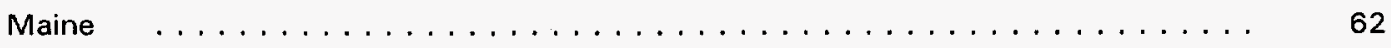

Maryland . . . . . . . . . . . . . . . . . . . . . . . . . . 62

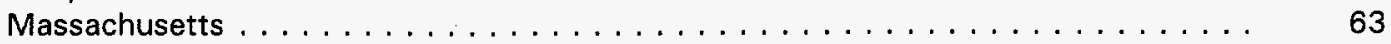

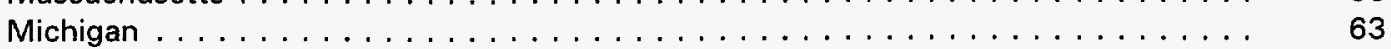

Minnesota ................................ 63 


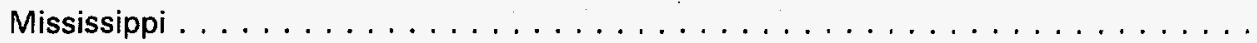

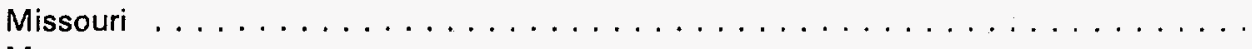

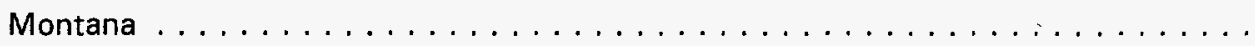

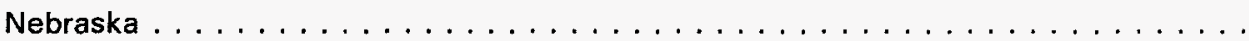

Nevada

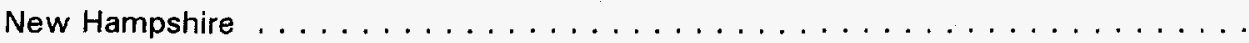

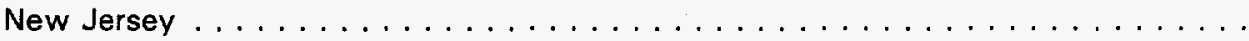

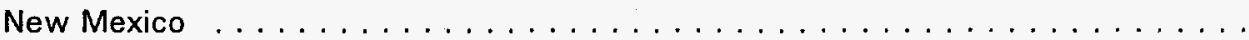

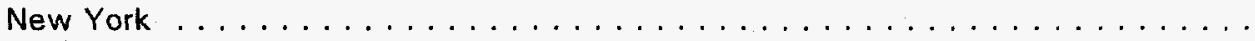

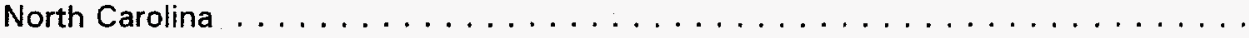

North Dakota . . . . . . . . . . . . . . . . . . . . . . .

Ohio

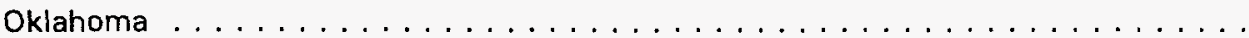

Oregon

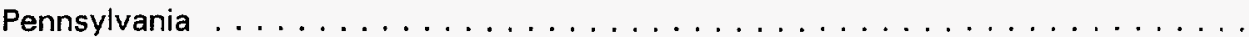

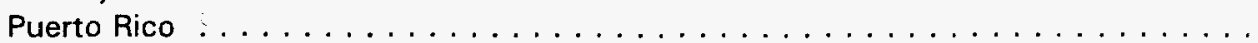

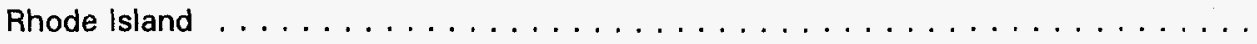

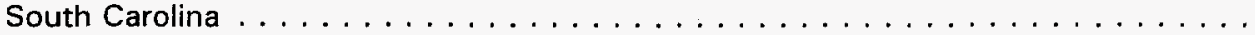

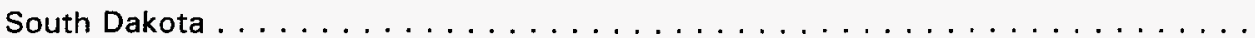

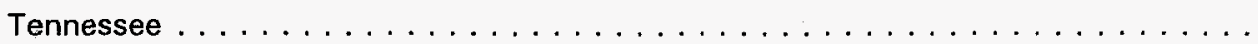

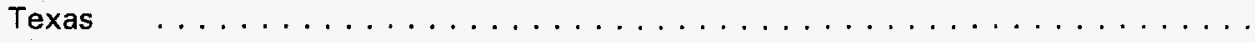

Utah

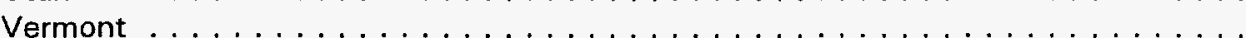

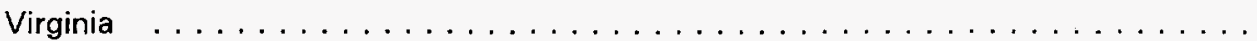

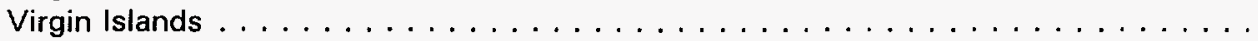

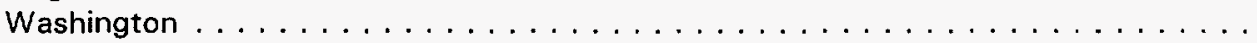

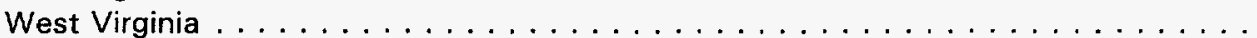

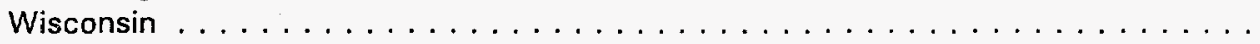

Wyoming

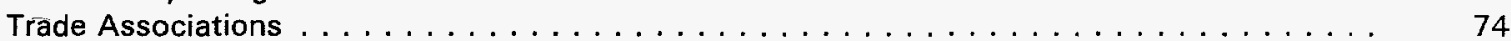

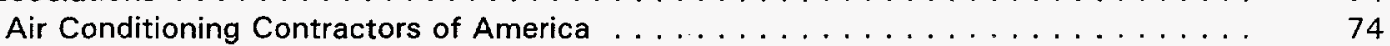

Air Transport Association of America (ATA) . . . . . . . . . . . . . . . . . . . 74

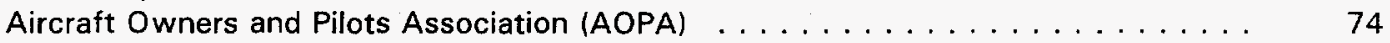

Air Diffusion Council . . . . . . . . . . . . . . . . . . . . . . . . . . . . . . 74

American Architectural Manufacturers Association (AAMA) . . . . . . . . . . . . . 74

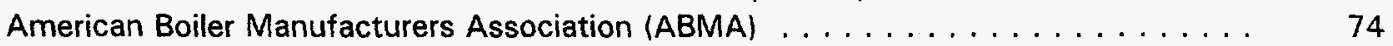

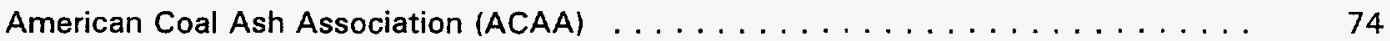

American Coal Foundation (ACF) $\ldots \ldots \ldots \ldots \ldots \ldots \ldots \ldots \ldots$

American College of Nuclear Physicians (ACNP) $\ldots \ldots \ldots \ldots \ldots \ldots \ldots \ldots$

American Consulting Engineers Council (ACEC) $\ldots \ldots \ldots \ldots \ldots \ldots$

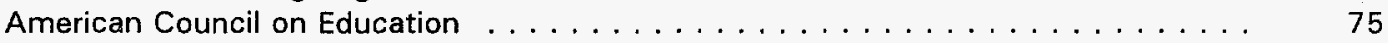

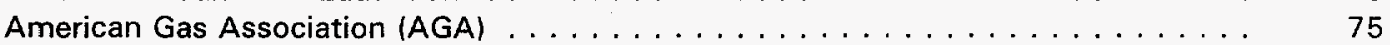

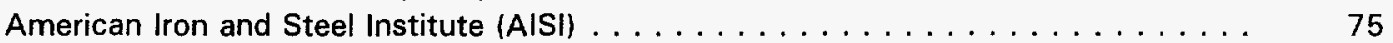

America Lighting Association (ALA) $\ldots \ldots \ldots \ldots \ldots \ldots \ldots \ldots$

American Nuclear Energy Council (ANEC) $\ldots \ldots \ldots \ldots \ldots \ldots \ldots \ldots$

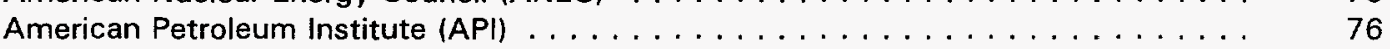

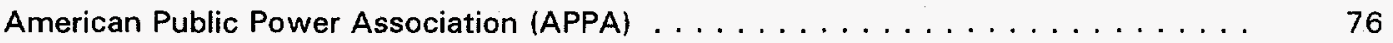

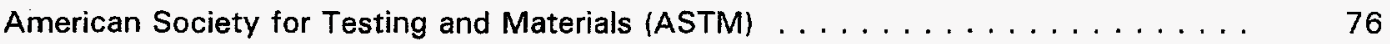

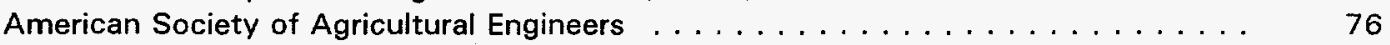

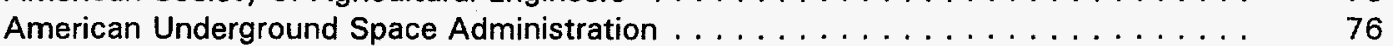

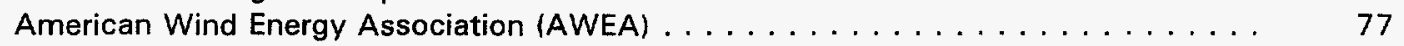

APA - The Engineered Wood Association . . . . . . . . . . . . . . . . . . . . . . . . . . 77

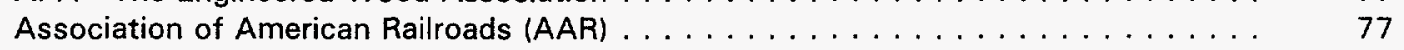

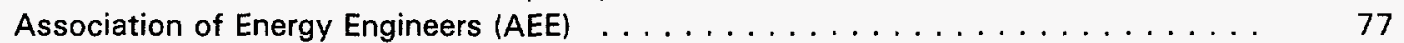

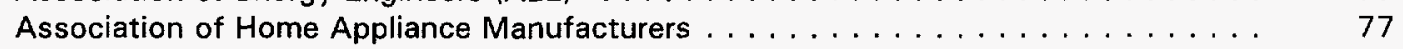

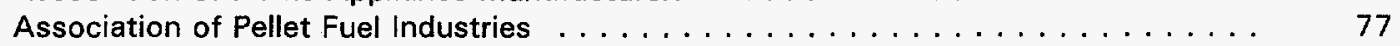

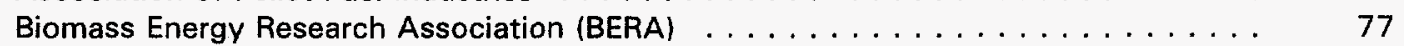

Brick Institute of America $\ldots \ldots \ldots \ldots \ldots \ldots \ldots \ldots \ldots \ldots \ldots$

Ceilings and Interior Systems Construction Association . . . . . . . . . . . . . 78

Consumer Energy Council of America Research Foundation (CECA/RF) . . . . . . . . 78

Cooling Tower Institute $(C T I) \ldots \ldots \ldots \ldots \ldots \ldots \ldots$ 
Council of Industrial Boiler Owners (CIBO) $\ldots \ldots \ldots \ldots \ldots \ldots \ldots \ldots$

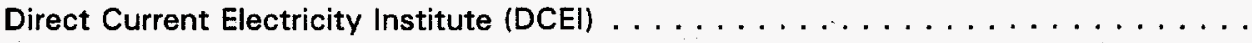

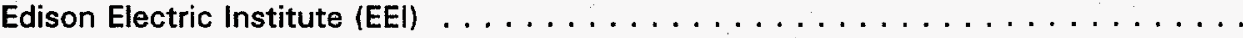

Electrical Generating Systems Association (EGSA) $\ldots \ldots \ldots \ldots \ldots \ldots$

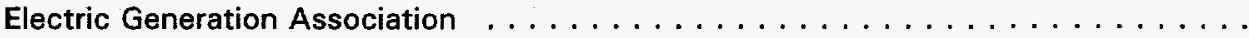

Electricity Consumers Resource Council (ELCON) $\ldots \ldots \ldots \ldots \ldots \ldots \ldots \ldots$

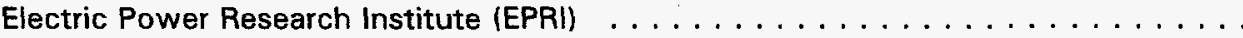

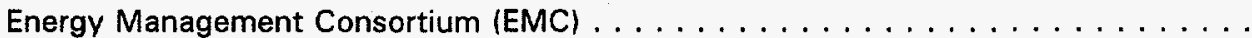

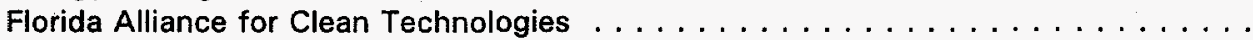

Gas Appliance Manufacturers Association (GAMA) . . . . . . . . . . . . .

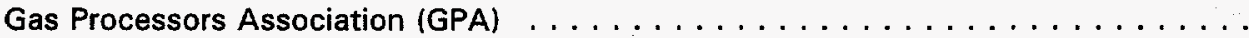

Gas Research Institute (GRI) $\ldots \ldots \ldots \ldots \ldots \ldots \ldots \ldots \ldots \ldots \ldots \ldots \ldots$

Hearth Products Association (HPA) $\ldots \ldots \ldots \ldots \ldots \ldots \ldots \ldots \ldots$

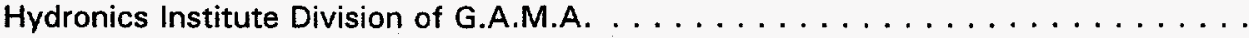

Illuminating Engineering Society of North America (IESNA) $\ldots \ldots \ldots \ldots \ldots$

Independent Electrical Contractors (IEC) $\ldots \ldots \ldots \ldots \ldots \ldots \ldots \ldots$

Independent Liquid Terminals Association (ILTA) $\ldots \ldots \ldots \ldots \ldots \ldots$

Independent Lubricant Manufacturers Association (ILMA) $\ldots \ldots \ldots \ldots \ldots \ldots$

Independent Petroleum Association of America (IPAA) $\ldots \ldots \ldots \ldots \ldots \ldots$

Institute of Gas Technology (IGT) $\ldots \ldots \ldots \ldots \ldots \ldots \ldots \ldots \ldots$

International Association of Drilling Contractors (IADC) $\ldots \ldots \ldots \ldots \ldots \ldots$

Interstate Natural Gas Association of America (INGAA) . . . . . . . . . . . .

National Association of Energy Service Companies (NAESCO) . . . . . . . . . . .

National Association of State Utility Consumer Advocates (NASUCA) . . . . . . . .

National Electrical Contractors Association, Inc. (NECA) $\ldots \ldots \ldots \ldots \ldots \ldots$

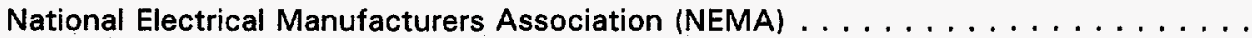

National Hydropower Association (NHA) $\ldots \ldots \ldots \ldots \ldots \ldots$

National Independent Energy Producers (NIEP) $\ldots \ldots \ldots \ldots \ldots \ldots \ldots \ldots$

National Institute for the Uniform Licensing of Power Engineers (NIULPE) $\ldots \ldots \ldots$

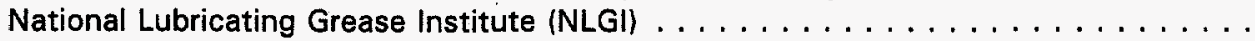

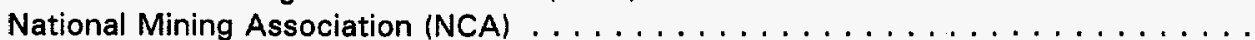

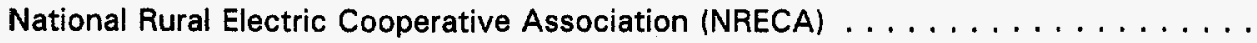

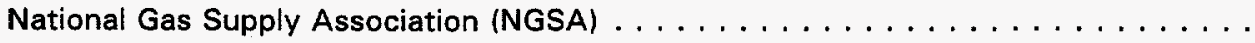

North America Electric Reliability Council (NERC) $\ldots \ldots \ldots \ldots \ldots \ldots \ldots$

Nuclear Energy Institute $\ldots \ldots \ldots \ldots \ldots \ldots \ldots \ldots \ldots \ldots \ldots \ldots \ldots$

Petroleum Marketers Association of America (PMAA) $\ldots \ldots \ldots \ldots \ldots \ldots$

Potential Gas Committee . . . . . . . . . . . . . . . . . . . . . . . . . .

Service Station Dealers of America and Allied Trades (SSDA-AT) . . . . . . . . .

United States Enrichment Corporation (USEC) 


\section{INFORMATION CENTERS}

1

\author{
Energy Efficiency and Renewable Energy \\ Clearinghouse (EREC) \\ P.O. Box 3048 \\ Merrifield, VA 22116 \\ (800) 363-3732 \\ Fax: (703) 893-0400 \\ BBS Line: (800) 273-2955 \\ E-Mail: doe.erec@nciinc.com \\ URL: http://www/eren.doe.gov
}

Provides information on the full spectrum of energy efficiency and renewable energy technologies, including active/passive solar, energy efficient appliances, biofuels production, independent power generation using renewable resources, recycling, waste-to-energy and weatherization materials and techniques. EREC also maintains contact with a nationwide network of public and private organizations that specialize in highly or regionally specific information. EREC is the successor to the Conservation and Renewable Energy Information and Referral Service and the National Appropriate Technology Assistance Services.

2

\author{
Energy Science and Technology Software \\ Center (ESTSC) \\ Walt Kelly, Director \\ P.O. Box 1020 \\ Oak Ridge, TN 37831-1020 \\ (423) 576-2606 \\ Fax: (423) $576-6436$
}

General Information

(423) 576-2606

E-Mail: estsc@adonis.osti.gov

URL: http://www.doe.gov/html/

osti/estsc/estsc.html

The Energy Science and Technology Software Center (ESTSC) is the U.S. Department of Energy's (DOE) centralized software management facility. Operated by the DOE Office of Scientific and Technical Information (OSTI), the ESTSC licenses and distributes Federally-funded software developed by the national laboratories, other facilities and contractors of DOE, and the U.S. Nuclear Regulatory Commission (NRC). This software represents the latest in Federal technology. In addition, the collection contains selected software from the Nuclear Energy Agency (NEA), in France, of the Organization for Economic Cooperation and Development (OECD). The ESTSC collects, processes, and disseminates scientific and technical software to the DOE community, other government organizations and their contractors, educational institutions, and the public, as appropriate; checks for package completeness; executes test cases, as requested; provides assistance and consultation on software implementation; and publishes descriptions of new and updated software packages for users. An on-line searchable software catalog, and other information about ESTSC, is available via the ESTSC Home Page.

3

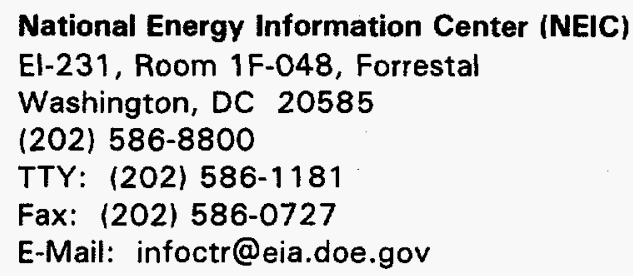

Provides statistical and analytical energy data, information, and referral assistance to the government and private sectors, academia, and the public. NEIC distributes EIA publications to the media, public libraries, Federal, State, and local governments, and EIA survey respondents. NEIC also provides Government Printing Office (GPO) ordering information. Single copies of blank data collection forms, directories, and EIA press releases are free of charge to all users. Ordering information on EIA machine-readable files available through the National Technical Information Service (NTIS) and the Government Printing Office may be obtained from NEIC. Ordering information on EIA'S CD Rom which is available through the Department of Commerce may be obtained from NEIC.

NEIC Subject Specialists

Coal

Karen Vassallo

Bill Horvath

Electric and Nuclear Power

Thomas Welch

William Jeffers

Media/Press Inquiries

Thomas Welch

Jonathan Cogan

Natural Gas

Paula Altman

Dan Diamond

Petroleum

Leola Withrow

Jonathan Cogan 
Renewable Energy Resources/Conservation

Marion King

Karen Freedman

Data Survey Forms

Single Copy Distribution

Karen Freedman

Information About Obtaining Machine-Readable Modeling Tapes, Data Files, and Diskettes (202) 586-8800

Information About Obtaining Microfiche of Publications

(202) 586-8800

4

National Institute for Petroleum and Energy Research (NIPER)

Winnie Ho

P.O. Box 2128

Bartlesville, OK 74005

(918) $337-4531$

Conducts research, development, and demonstration efforts covering all phases of liquid fossil fuel technology. Includes research on petroleum extraction using enhanced oil recovery methods and improved drilling technology; the extraction of natural gas from Western tight sands processing and thermodynamic properties of conventional oils, as well as liquid products made from coal, oil shale, and tar sands; recycling of waste lubricating oil; and improving automotive engine emissions. A data bank on crude oil recovery is available to the public. In addition, NIPER will solicit research from the private sector as well as from other Government agencies.

\section{5}

Office of Scientific and Technical

Information (OSTI)

Elizabeth V. Buffum, Director

R. Charles Morgan, Technical Operations

Director

Department of Energy

P.O. Box 62

Oak Ridge, TN 37831

(423) $576-1188$

Fax: (423) 576-2865

Provides direction and leadership for the Departmentwide Scientific and Technical Information Program, which serves the information needs of DOE and contractor facilities. OSTI collects, processes, and disseminates information resulting from DOE research projects, as well as worldwide information on subjects of interest to DOE researchers; serves as the central processing and distribution point and repository for DOE scientific and technical reports; and develops data bases to provide access to energy literature, DOE research in progress, and DOEdeveloped software. OSTI also maintains a registry of energy publications produced by the Department for the public; develops specialized information systems and products in response to the needs of DOE program managers; represents DOE in international technical information exchanges, for example with the International Energy Agency and the International Atomic Energy Agency; and provides energy information to the public through the National Technical Information Service.

General Information

(423) $576-1188$

Technical Reports

(423) $576-8401$

Data Bases

(423) $576-1175$ 


\section{DEPARTMENT OF ENERGY/WASHINGTON}

\section{Departmental Advisory Committees}

\author{
6 American Statistical Association \\ Committee on Energy Statistics (ASA) \\ Renee Miller \\ EI-72, Room 7042 \\ 950 L'Enfant Plaza \\ Washington, DC 20585 \\ (202) 426-1117
}

Originally chartered on October 17,1984 , to utilize the expertise of ASA for review of elements of EIA information collection and analysis programs; to advise on technical and methodological issues in the planning, operation, and review of EIA statistical programs; and to advise on matters concerning improved energy modeling and forecasting tools. The charter has been renewed every two years since 1984.

7 Secretary of Energy Advisory Board (SEAB) David W. Cheney, Acting Executive Director AB-1, Room 8E-044

Forrestal Building Washington, DC 20585

(202) 586-4303

Fax: (202) 586-6279

Manages the activities of the Secretary of Energy Advisory Board in providing advice to the Secretary of Energy on issues related to the Department of Energy and the Nation's future energy and national security needs.

\section{Departmental Program Offices}

8

\author{
Office of the Assistant Secretary for \\ Congressional, Public and Intergovernmental \\ Affairs (CP) \\ Dirk L. Forrister, Assistant Secretary \\ CP-1, Room 7A-145, Forrestal Building \\ Washington, DC 20585 \\ (202) 586-5506
}

Robert M. Alcock, Acting

Principal Deputy Assistant Secretary CP-1, Room 7B-138, Forrestal Building Washington, DC 20585

(202) $586-5450$

Responsible for management and oversight of the Department's liaison with Members of Congress, other levels of governments, public affairs efforts, which include public information activities, press and media services, consumer liaison, public interest groups, publication of special information materials legislative research, special projects, and internal communications. The mission and its incumbent responsibilities are served by the Office's functioning as a "one-stop shop" for information about the Department's energy, national security, science and environmental business lines. The Office ensures the release of timely, factual information, and creates opportunities for early customer involvement in the Department's decisionmaking process.

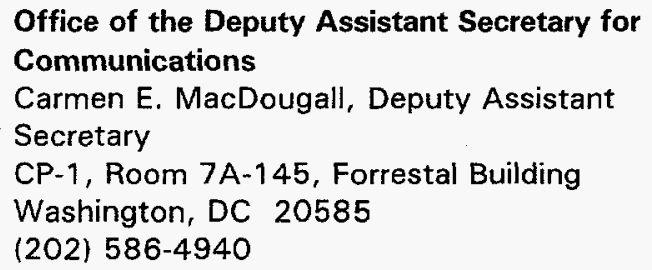

Serves as the chief spokesperson for the Secretary and other Principal Secretarial Officers. Responsible for oversight and management of press relations and coordination of these efforts with program offices; providing information on energy and DOE programs to the public and Department employees; and management of information developed for public dissemination through a review of proposed publications, audiovisuals, and exhibits.

Office of the Deputy Assistant Secretary for House Liaison

Melanie A. Kenderdine, Deputy Assistant

Secretary

CP-1, Room 7B-118, Forrestal Building

Washington, DC 20585

(202) $586-5468$

Office of the Deputy Assistant Secretary for Senate Liaison

Mary Louise Wagner

CP-1, Room 7B-118, Forrestal Building

Washington, DC 20585

(202) $586-5468$

These Offices provide advice and expertise and serve as advisors to DOE officials on legislative policies and legislative initiatives in working with the Congress and developing legislative strategies to support the DOE's energy policies and programs. In addition, these Offices work closely with Members of Congress to ensure Members' concerns are communicated to senior Departmental officials. 
T. J. Hopkins, Director

CP-10, Room 8E-070, Forrestal Building

Washington, DC 20585

(202) $586-1351$

Responsible for the support activities associated with congressional, public, and intergovernmental affairs' day-to-day activities. Staff provide policy advice on administration, management, and human resources to the Assistant Secretary and other staff.

Office of Research and Editorial Services Jack J. Jenkins, Director CP-20, Room 8E-082, Forrestal Building Washington, DC 20585

(202) 586-2052

Provides responsive and timely research and analysis to Departmental officials on legislative and other general energy issues. Responsible for producing effective presentations for the Secretary's public events and providing general information in accordance with the Secretary's policy of openness and credibility.

\section{Office of Communications/Press Secretary Barbara Semedo, Press Secretary CP-40, Room 8G-087, Forrestal Building Washington, DC 20585 (202) $586-5806$}

Responsible for providing day-to-day expertise for press relations for the Department coordinating these efforts with Program Secretarial Officers. Responds to press inquiries, arranges and conducts press conferences and ensures that the general public is aware of energy policies and programs.

\section{4}

\author{
Office of Communications/Internal \\ Communications \\ F. Chester Gray, Director \\ CP-41, Room 8H-068, Forrestal Building \\ Washington, DC 20585 \\ (202) $586-6827$
}

Responsible for providing information on energy and Departmental programs to the public and Departmental employees; and managing information developed for public dissemination through a review of proposed publications, audiovisuals, and exhibits. In addition, reviews and prepares news clips on energy issues published in newspapers and magazines.
Office of the Deputy Assistant Secretary for Intergovernmental and External Affairs Robert M. Alcock, Deputy Assistant Secretary CP-50, Room 7B-138, Forrestal Building Washington, DC 20585 (202) $586-5450$

Elizabeth A. Nolan, Director CP-50, Room 7B-164, Forrestal Building Washington, DC 20585

(202) $586-5373$

Responsible for management and oversight of liaison activities involving State, local, territorial and Tribal governments; and environmental and industry components concerned with the development and implementation of national energy policies and programs. Builds partnerships with these groups to identify and pursue national energy priorities; and provides an intergovernmental perspective for senior Departmental officers.

\section{6}

\author{
Office of Congressional Liaison \\ Elizabeth A. Cecchetti, Director \\ CP-60, Room 8G-026, Forrestal Building \\ Washington, DC 20585 \\ (202) 586-2764
}

Serves as the central point of contact for Congressional activities and provides a key liaison function on a day-to-day basis to Departmental officials in developing legislative strategies and providing expertise on congressional interests and issues regarding legislation and hearings on sensitive legislative proposals. In addition, staff works closely with Members of Congress and their staffs to communicate and articulate the Department's policies and programs.

\section{Functional Listings}

Audiovisuals and Exhibits

(202) $586-4670$

Consumer Affairs/Public Liaison (202) 586-5373

DOE This Month

(202) 586-2050

Press Office

(202) 586-5806

Publications/Public Inquiries

(202) 586-5575

Speakers' Bureau

(202) 586-5373 
Office of the Assistant Secretary for Defense Programs (DP)

\section{7}

\author{
Office of the Deputy Assistant Secretary for \\ Research and Development \\ Robin Staffin, Deputy Assistant Secretary \\ DP-10, Room 4A-045, Forrestal Building \\ Washington, DC 20585 \\ (202) 586-7590
}

Oversees and directs the programs and related facilities for nuclear weapons research, development, and testing (restructured and renamed Stockpile Stewardshipl, excluding specific weapons production and testing facilities; provides leadership in the establishment of a partnership between the Defense Programs laboratories and Defense Programs to preserve laboratory core competencies and technology base and ensure the enduring health and vitality of the national laboratories, and provides management for the National Ignition Facility, Dual Axis Radiological Hydrodynamic Test Facility, and the Advanced Hydrodynamic Facility.

\section{Office of Research, Development and Testing Facilities \\ Dennis M. Miotla, Director \\ DP-13, Room D-403 \\ 19901 Germantown Road \\ Germantown, MD 20874 \\ (301) 903-5427}

Provides management direction to the Department's Defense Programs research, development and testing facilities at Lawrence Livermore National Laboratory, Los Alamos National Laboratory, Sandia National Laboratory and the Nevada Test Site, assuring their operation and maintenance in a safe, environmentally sound, secure, efficient and reliable manner.

\author{
Office of Defense Programs Laboratories \\ and Reimbursable Programs \\ Maurice J. Katz, Director \\ DP-15, Room GA-087, Forrestal Building \\ Washington, DC 20585 \\ (202) 586-6385
}

Provides leadership in the establishment of a partnership between the three national laboratories (Los Alamos, Sandia, and Lawrence Livermore) and the Assistant Secretary for Defense Programs. This partnership will preserve the national laboratory core competencies to assure they continue as vital and healthy institutions to support future national Defense Programs requirements. Serves as the Defense Programs focal point for laboratory institutional and strategic planning and ensures consistency and uniformity in the evaluation process utilized for the three laboratories. Assumes a primary role in reviewing and approving work programs for laboratory-directed research and development and for non-DOE sponsors (Work for Others) at the laboratories. Serves as the principal DP liaison to outside scientific organizations, as well as the National Science and Technology Council. Also manages and funds DP science education programs.

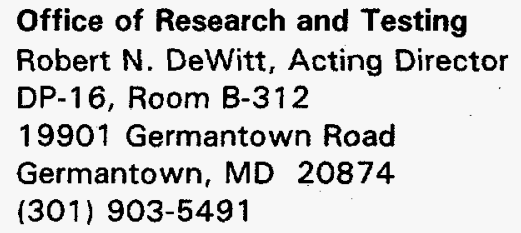

Manages research and development activities associated with weapons science and engineering, and maintains the Department's capability to design new weapons and conduct underground tests, if directed. Provides programmatic oversight of research and enabling technology development activities for the Defense Programs National Security Strategy and participates in threat assessment activities in support of that strategy. Plans, coordinates, and implements basic policies for Defense Programs integrated theoretical and experimental activities in support of the stockpile, and oversees a wide variety of experimental facilities and activities related to nuclear weapons technology, such as radiography, accelerators, and pulsed power, including the use of the Nevada Test Site. Activities assure the technology base for the surety, reliability, credibility, and military effectiveness of the nuclear weapons stockpile, the maintenance of the laboratory technology infrastructure and core competencies, the restructure of the weapons complex through advanced technology, and associated science and technology infrastructure for DOE non-proliferation and counter-proliferation activities.

\section{Office of Development and Technology Transfer James L. Van Fleet, Director DP-17, Room 1 J-077, Forrestal Building Washington, DC 20585 (202) $586-5782$}

Plans, coordinates, initiates and implements basic policies for Defense Programs development and technology transfer activities required to support the enduring stockpile and the DP mission. Manages the dual-benefit development and technology transfer programs between the private sector and DP laboratories and facilities that enhance the technology infrastructure and core competencies necessary for the execution of the DOE national security mission while contributing to U.S. industrial competitiveness. 
Office of Inertial Fusion and Ignition Facility

(IF) Project

David H. Crandall, Director

DP-18, Room 4A-045, Forrestal Building

Washington, DC 20585

(202) 586-7349

Provides leadership of activities related to research, development, demonstration, and utilization of laser and particle beam initiated inertial fusion and related to development of facilities, including pulsed power, for stockpile stewardship experiments. Provides management direction of the national IF project whose mission is to produce ignition and modest energy gain in inertial confinement fusion targets in support of national security and civilian objectives.

23 Office of the Deputy Assistant Secretary for Military Application and Stockpile Management

Thomas P. Seitz, Deputy Assistant Secretary DP-20, Room 4B-014, Forrestal Building

Washington, DC 20585

(202) $586-4879$

Oversees implementation of programs for nuclear weapons and material management, weapons surety, emergency response, weapons facilities operations, and complex reconfiguration. Provides executive level coordination between Office operations and the special national security staff activities for which the Office is responsible including preparation of the Nuclear Weapons Stockpile Memorandum.

\author{
Office of the Associate Deputy Assistant \\ Secretary for Military Application and \\ Stockpile Management \\ Richard W. Brown, Acting Associate Deputy \\ Assistant Secretary \\ DP-20.1, Room A-347 \\ 19901 Germantown Road \\ Germantown, MD 20874 \\ (301) 903-2967
}

Responsible for carrying out the Department's responsibilities to achieve national security objectives established by the President, and assists in reducing the global nuclear danger by planning for and maintaining a safe, secure, and reliable stockpile of nuclear weapons and associated materials, capabilities and technologies in an environmentally sound and cost-effective manner. Directs liaison activities between the Department and the Department of Defense on joint weapons stockpile, surety, and other highly important matters. Also coordinates weapons programming and budget matters with the Department of Defense.

\author{
Office of Weapons Surety \\ David L. McConagha, Director \\ DP-21, Room A-384 \\ 19901 Germantown Road \\ Germantown, MD 20874 \\ (301) 903-3463
}

Manages the Department's nuclear weapons surety program. Serves as advisor to the senior management staff of the agency regarding all aspects of this activity which include safety, security, and use control. Provides support to programs such as emergency response and counterproliferation. Represents the agency in interagency and international weapons surety activities.

\section{6}

\author{
Office of Nuclear Weapons Management \\ Richard D. Hahn, Director \\ DP-22, Room B-301 \\ 19901 Germantown Road \\ Germantown, MD 20874 \\ (301) 903-2402
}

Develops, manages, and directs the planning and execution of the stockpile support and materials policies and programs to ensure that national defense requirements are met. Responsible for ensuring the safe and effective operations and maintenance of the Kansas City Plant and for ensuring that production requirements are achieved.

\section{Office of Emergency Response \\ Lisa E. Gordon-Hagerty, Director \\ DP-23, Room B-318 \\ 19901 Germantown Road \\ Germantown, MD 20874 \\ (301) $903-3558$}

Administers and directs the programs of the Department's emergency response capability to ensure availability and viability to respond to nuclear and radiological emergencies within the U.S. and abroad. This capability includes seven major radiological emergency response assets/capabilities. Provides overall management and direction for the development and maintenance of Defense Programs' Emergency Management System at all DP facilities.

\section{8}

\author{
Office of Site Operations \\ Daniel R. Rhoades, Director \\ DP-24, Room C-425 \\ 19901 Germantown Road \\ Germantown, MD 20874 \\ (301) 903-3757
}

Manages the Department's stockpile support sites at Y-12 Plant, Savannah River tritium facilities and the Pantex Plant while assuring their safe and effective operations and maintenance. 
Office of Advanced Design and Production

Technologies

Charles E. Stuart, Acting Director

DP-26, Room 4B-014, Forrestal Building

Washington, DC 20585

(202) $586-2200$

Manages the development of innovative technologies and methods necessary to create an integrated, costeffective and agile design and manufacturing complex for nuclear weapons; and assists the weapons complex to shift from skilled worker and capability-based design and manufacturing to a process and technology-based complex which provides flexible and efficient production capability.

30 Office of the Deputy Assistant Secretary for Program Support

David B. LeClaire, Deputy Assistant

Secretary

DP-40, Room C-410

19901 Germantown Road

Germantown, MD 20874

(301) 903-4016

Directs budget and financial management and program analysis, human resource management, and management support activities for Defense Programs; manages legislative analysis and external affairs efforts; and directs technical support and related services to DP line managers and other Departmental elements in the areas of engineering, operations support, environment, safety and health, waste minimization and pollution prevention programs, weapons data management, safeguards and security, facility transition, and management of capital projects.

Office of the Associate Deputy Assistant Secretary for Analysis and Financial Management

Anthony R. Lane, Associate Deputy

Assistant Secretary

DP-41, Room A-337

19901 Germantown Road

Germantown, MD 20874

(301) $903-4245$

Responsible for directing and conducting DP's strategic planning, financial management, legislative analyses, and public affairs activities.
Office of the Associate Deputy Assistant Secretary for Human and Administrative Resources

Edwin F. Inge, Jr., Associate Deputy

Assistant Secretary

DP-44, Room C-460

19901 Germantown Road

Germantown, MD 20874

(301) $903-5553$

Responsible for overseeing DP's personnel, organization and manpower, training and staff development, procurement, data processing, and other administrative and support services activities.

Office of the Deputy Assistant Secretary for Technical and Environmental Support Henry K. Garson, Associate Deputy

Assistant Secretary

DP-45, Room B-109

19901 Germantown Road

Germantown, MD 20874

(301) 903-0470

Provides long-range, integrated planning for DP's National Environmental Policy Act (NEPA) compliance activities, along with coordination, integration, oversight and support for ongoing activities both within the Department and with other cooperating Federal agencies. Manages activities to prevent pollution and minimize waste generation from the operation of DP facilities; and provide regulatory and policy support to line management or DP facilities for matters relating to environmental laws including the Clean Air Act (CAA) and the Clear Water Act (CWA), the Safe Drinking Water Act (SDWA), the Resource Conservation and Recovery Act (RCRA), the Toxic Substance Control Act (TSCA), and the Comprehensive Environmental Response, Compensation and Liability Act (CERCLA).

Office of the Deputy Assistant Secretary for Strategic Computing and Simulation/Senior Information Officer

Gilbert G. Weigand, Deputy Assistant

Secretary

DP-50, Room 4A-045, Forrestal Building

Washington, DC 20585

(202) 586-0568

Responsible for overall policy, planning and management of the Nation's nuclear weapons and related technology programs in a safe, secure, environmentally sound and cost effective manner. Provides leadership and oversight in the development of DP's information technology and systems in support of national defense objectives and U.S. leadership and competitiveness in the information age. 
Office of Strategic Computing and Modeling

Alexander R. Larzelere, Acting Director

DP-51, Room 1J-077, Forrestal Building

Washington, DC 20585

(202) 586-1000

Develops plans and program guidance and provides input for DP's Accelerated Strategic Computing Initiative. Provides Headquarters oversight to the development of advanced computational applications for the weapons program. Coordinates the development of information technology and infrastructure for the weapons complex. Monitors the development of a computing and communications network to link and integrate weapons analysis, modeling and simulation activities.

\author{
Office of Stockpile Computation and \\ Modeling \\ Vacant, Director \\ DP-52, Room 1 J-077, Forrestal Building \\ Washington, DC 20585 \\ (202) $586-1000$
}

Manages, plans, coordinates and implements the Accelerated Strategic Computing Initiative and its interface with other DP offices, DOE organizations, government agencies, industry, and academia.

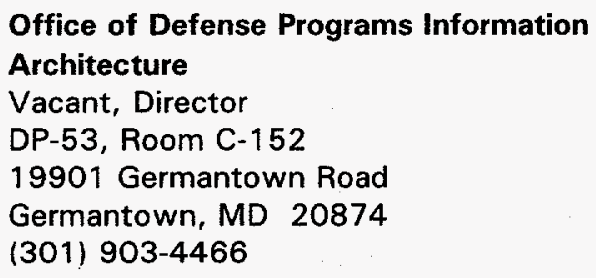

Provides policy, guidance, coordination and integration of DP's information and information management functions in support of the DP Senior Technical Information Officer.

Tritium Project Office

Eldon W. Joersz, Maj. Gen., USAF, Director DP-60, Room 4A-019, Forrestal Building Washington, DC 20585

(202) 586-7972

Manages and directs the dual track strategy for tritium production to enable a complete and comprehensive review of production options in the planning and development of a tritium production facility to assure the production of tritium as required for the U.S. nuclear weapons stockpile.

\author{
Office of Accelerator Production \\ William P. Bishop, Acting Director \\ DP-61, Room 5B-168, Forrestal Building \\ Washington, DC 20585 \\ (202) 586-0046
}

Provides leadership in the comprehensive review of the strategy to solve long-term tritium supply needs to meet stockpile requirements through the design, construction and testing of an accelerator system for tritium production.

40

\author{
Office of Commercial Light Water Reactor \\ Production \\ Stephen M. Sohinki, Director \\ DP-62, Room 5B-168, Forrestal Building \\ Washington, DC 20585 \\ (202) 586-0838
}

Provides leadership in the comprehensive review of the strategy to solve long-term supply needs to meet stockpile requirements through commercial light water reactor production, as either the preferred production approach or as an assured backup capability.

\section{Office of Economic Impact and Diversity (ED)}

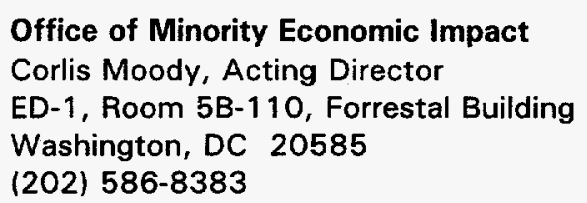

Develops comparative socioeconomic analyses of minority energy consumption and use patterns; determines the effects of energy prices; and implements focused educational and increased technical, business, and financial assistance programs which will enhance the social and economic conditions of minorities. Programs focus on developing and implementing fluid methods to determine both the income distribution and employment effects associated with related energy policies and programs among disadvantaged population segments. Develops, enhances, and establishes programs to increase minority participation in both the Department's and the energy industry's research and demonstration, grant, contract, and other program opportunities; increases their levels of involvement in the development and commercialization of energy technology alternatives; implements strategies to enhance the technical and scientific skills of minorities and the quality of the minority educational infrastructure; improves the business skills and participation of minorities in the high-technology energy industry segments; and develops and disseminates technical information to assist focused developmental strategies in minority and low-income communities. 
Office of Small and Disadvantaged Business Utilization

Corlis Moody, Director

ED-3, Room 5B-110, Forrestal Building

Washington, DC 20585

(202) 586-5583

Responsible for policy, plans, implementation, and oversight of functions relating to preference programs for small businesses; labor surplus area concerns; women-owned businesses; and minority-owned businesses, educational institutions, and organizations. Provides functional direction and oversight to Headquarters and field personnel in regard to execution of these programs.

43 Office of the Assistant Secretary for Energy Efficiency and Renewable Energy (EE)

Christine A. Ervin, Assistant Secretary EE-1, Room 6C-016, Forrestal Building Washington, DC 20585

(202) $586-9220$

Formulates and directs programs designed to increase the production and utilization of renewable energy and improve the energy efficiency of the transportation, buildings, industrial, and utility sectors through support of research, development, and technology transfer activities. Administers statutorily mandated assistance programs. Brings an outside focus to bear in renewable energy and energy efficiency issues by involving external constituencies.

44 Office of the Deputy Assistant Secretary for Utility Technologies

Allan R. Hoffman, Acting Deputy Assistant Secretary

EE-10, Room 6B-128, Forrestal Building

Washington, DC 20585

(202) 586-9275

Formulates, articulates, executes, and evaluates a national program of technology planning, research and development, and test and evaluation for renewable energy and energy measurement technologies in the utility sector. Develops utility technology policies and priorities by evaluating national and Departmental economic, environmental, and energy policies and statutes, domestic and international energy demands and utilization, and Federal funding availability. Office activities center around the technology of renewable and solar energy conversion and advanced utility concepts. Develops, executes, and evaluates programs and activities to affect timely transfer of technòlogy from Federal laboratories to energy production concerns.

\author{
Office of Photovoltaic and Wind \\ Technologies \\ Ronald Loose, Director \\ EE-11, Room 6B-104, Forrestal Building \\ Washington, DC 20585 \\ (202) $586-5348$
}

Provides overall direction, interprets policy objectives, establishes management procedures, and plans and manages a balanced program for technology research, development, testing, evaluation and communication that will foster the establishment of photovoltaic and wind energy technology supply options.

46

\author{
Office of Geothermal Technologies \\ Allan Jelacic, Director \\ EE-12, Room 5H-065, Forrestal Building \\ Washington, DC 20585 \\ (202) $586-6054$
}

Plans and manages a balanced program for technology research, development, testing and evaluation that will foster the establishment of geothermal technology supply and demand.

47

\author{
Office of Solar Thermal, Biomass Power \\ and Hydrogen Technologies \\ Gary D. Burch, Director \\ EE-13, Room $5 \mathrm{H}-088$, Forrestal Building \\ Washington, DC 20585 \\ (202) 586-0081
}

Provides overall direction, interprets policy objectives, and establishes management procedures for a balanced program of technology planning, research, development, test, analysis, evaluation, and communication that will foster the establishment of solar thermal electric, biomass power, and hydrogen technologies supply as options for use by utilities and allied industries and institutions.

\section{8}

\author{
Office of Energy Outreach \\ Ronald Bowes, Director \\ EE-14, Room 5E-036, Forrestal Building \\ Washington, DC 20585 \\ (202) 586-5517
}

Develops programs that provide technical assistance to a wide range of energy users and renewable energy and energy efficiency industries. Works with the Joint Venture/International and Tribal Government Programs. 
Office of the Deputy Assistant Secretary for Industrial Technologies

Denise F. Swink, Deputy Assistant Secretary EE-20, Room 6B-052, Forrestal Building

Washington, DC 20585

(202) $586-9232$

Manages a national program of technology planning research and development designed to increase energy end-use efficiency to promote renewable energy use in industrial applications and enhance industrial productivity. The program also aims to reduce industrial and municipal waste stream volume and associated environmental impact and hazard through selective support of research and development leading to minimization, treatment, detoxification, and reuse of waste stream materials. Identifies, supports, and transfers the results of research in combustion, heat transfer, thermodynamics, mechanics, materials chemistry processing, electrochemistry, and biocatalysis to commercial practice.

\section{0}

\author{
Office of Industrial Strategies \\ Kurt D. Sisson, Director \\ EE-21, Room 5F-035, Forrestal Building \\ Washington, DC 20585 \\ (202) 586-0139
}

Facilitates industry technological development by working one-on-one with industry representatives.

\section{Office of Industrial Process Systems \\ Doug Kaempf, Acting Director \\ EE-22, Room 5F-035, Forrestal Building \\ Washington, DC 20585 \\ (202) $586-5584$}

Supports the seven industries of the Future through the implementation of strong National programs of research and development that are aligned with industry needs as articulated in industry visions, road maps and implementation plans.

\section{Office of Industrial Crosscut Technologies} William Parks, Director EE-23, Room 5F-035, Forrestal Building Washington, DC 20585

(202) 586-2093

Conducts research and development on technologies to improve the energy efficiency of cross-industry technologies, advance industry's technological leadership, and enhance its competitive position.

\author{
Office of Technology Access \\ Marsha Quinn, Director \\ EE-24, Room 5F-035, Forrestal Building \\ Washington, DC 20585 \\ (202) 586-2097
}

Charged with providing industry access to technologies that generate benefit and contribute to energy efficiency. Programs such as Motor Challenge and National Industrial Competitiveness Through Energy Environment and Economics (NICE ${ }^{3}$ ) are examples of the Office's programs in energy efficiency specifically targeting industry.

\section{4}

\author{
Office of the Deputy Assistant Secretary for \\ Transportation Technologies \\ Thomas J. Gross, Deputy Assistant \\ Secretary \\ EE-30, Room 6B-094, Forrestal Building \\ Washington, DC 20585 \\ (202) $586-8027$
}

Manages programs that will significantly reduce the transportation sector's requirements for imported oil, while concurrently reducing transportation sector generation of greenhouse gases and pollutants. Helps ensure its domestic transportation industry partners are competitive world leaders with access to a strong scientific and engineering base. Evaluates economic, environmental, and energy policies and statutes; current and prospective domestic and international transportation energy demands and utilization; and appropriate application of Federal funds. Is responsible for defining and implementing programs that realize the economic and technical potential of advanced transportation technologies; reflect industrial, economic, and financial concerns; and account for the capabilities, decisions, and interests of energy users. Assures that transportation technologies are properly reflected in the formulation of national energy and economic policies. Coordinates national and international programs having a bearing upon the competitive position of U.S. industry.

\section{5}

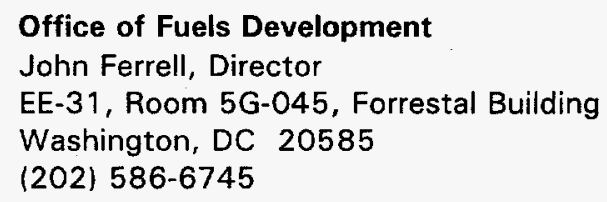

Formulates, articulates, executes, and coordinates a balanced and customer-focused national program of technology planning, applied research, development, and demonstration to support the availability of costcompetitive, domestic, renewable fuels for use in the transportation sector. 


\author{
Office of Advanced Automotive \\ Technologies \\ Kenneth F. Barber, Director \\ EE-32, Room 5G-030, Forrestal Building \\ Washington, DC 20585 \\ (202) $586-8055$
}

Engages the technical and financial resources of the government, the automotive and fuels industries, their suppliers, and universities in a customerfocused national program to research and develop advanced automotive technologies and support their integration into affordable automobiles.

\section{7}

\author{
Office of Heavy Vehicle Technologies \\ James Eberhardt, Director \\ EE-33, Room 5G-064, Forrestal Building \\ Washington, DC 20585 \\ (202) $586-9837$
}

Conducts, in collaboration with its heavy vehicle industry partners and their suppliers, a customerfocused national program to research and develop technologies to enable the U.S. heavy vehicle transportation industry to fully exploit the energy efficiency and alternative fuel capabilities of the diesel engine, and other potential propulsion systems, while simultaneously enhancing air quality.

\section{8}

\author{
Office of Technology Utilization \\ Richard Moorer, Acting Director \\ EE-34, Room 5G-086, Forrestal Building \\ Washington, DC 20585 \\ (202) $586-8038$
}

Introduces alternative fuel vehicle technology (fuels, vehicles, infrastiucture) into the domestic transportation system in a safe, economical and businesslike manner. Is organized to accomplish three distinct, yet interconnected, functions: Fleet Test Operations, Clean Cities, and activities related to alternative fuel provisions of the Energy Policy Act.

\author{
Office of the Deputy Assistant Secretary for \\ Building Technology, State and Community \\ Programs \\ Mark Ginsberg, Acting Deputy Assistant \\ Secretary \\ EE-40, Room 6A-081, Forrestal Building \\ Washington, DC 20585 \\ (202) 586-1510
}

Formulates, articulates, executes, and evaluates a national program for building energy efficiency. The mission includes technology planning, research and development, test and evaluation, market development, and codes, standards and labelling efforts to provide effective support to private sector efforts to increase the energy efficiency of the
Nation's residential, commercial and industrial buildings as well as to enhance the utilization of active and passive solar systems for building energy supply options. Is responsible for accelerating the use of energy efficiency and renewable energy technologies in buildings and other sectors, through financial and technical assistance to state and local entities. Performs energy efficiency planning and management programs for Federal Buildings. Provides associated information and financial incentives and performs regulatory functions as determined by the Federal government.

\section{0}

\author{
Office of Building Systems \\ Richard Karney, Director \\ EE-41, Room $5 \mathrm{H}-098$, Forrestal Building \\ Washington, DC 20585 \\ (202) $586-9445$
}

Develops and manages a balanced program of technology planning, research and development, test and evaluation, and deployment providing an effective technical basis for substantially increasing the energy efficiency of new and existing buildings. Programs are oriented to enhance private sector activities in the area of building energy sciences, including passive solar building technologies. These efforts provide the scientific and technical basis upon which to advance knowledge of energy phenomena in buildings.

\section{Office of Building Equipment John Ryan, Director EE-42, Room 5H-048, Forrestal Building Washington, DC 20585 (202) 586-9130}

\begin{abstract}
Formulates, articulates, executes and evaluates a national program of technology planning, research, development, and deployment to provide the private sector with the technological basis for developing and testing high efficiency and solar equipment used in residential and commercial buildings. The equipment of concern supplies the heating, cooling, lighting, hot water, and other services needed to operate a building efficiently and offer its occupants a comfortable, safe environment.
\end{abstract}

\section{2}

\author{
Office of Codes and Standards \\ Michael J. McCabe, Director \\ EE-43, Room 1J-018, Forrestal Building \\ Washington, DC 20585 \\ (202) 586-9127
}

Formulates programs to implement the legislative requirements for building energy performance standards and appliance efficiency standards. Implementation of the requirements of the Appliance Standards legislation requires the development, revision, and update of the DOE test procedures for 
consumer products. These procedures are used by manufacturers of major residential appliances to compute energy information needed for appliance energy guide labels. Comprehensive analysis is also performed for the purpose of setting maximum energy efficiency standards that are technologically feasible, economically justified, and conserve significant amounts of energy.

63 Office of State and Community Programs Jeanne Van Vlandren, Director EE-44, Room 5E-080, Forrestal Building Washington, DC 20585 (202) 586-4074

Strengthens the U.S. economy and improves living standards; reduces environmental impacts associated with energy delivery and use; and promotes economic and regional equity for all Americans through the accelerated use of energy efficiency and renewable energy technologies and practices.

\section{4}

\author{
Office of Management and Operations \\ Marvin E. Gunn, Jr., Director \\ EE-60, Room 6C-036, Forrestal Building \\ Washington, DC 20585 \\ (202) 586-6768
}

Serves as the management policy development, implementation, and oversight arm of the Assistant Secretary. Acts as a consultant and advisor to the Assistant Secretary and line organizations in areas such as management policy, budget preparation and execution, program management review, facilities coordination and utilization, internal/external communications, and administrative support.

Provides management oversight/support to the Energy Efficiency Regional Support Offices whose mission is to implement and support the policies and programs of the Assistant Secretary by increasing the use of energy efficiency and renewable energy technologies in the four sectors of the assigned geographical areas; to provide EE information on the requirements of these sectors for energy efficiency technologies; and to support other Departmental elements as directed. In addition, the support offices perform technology deployment activities and partner with customers and stakeholders in the field.

\section{Energy Efficiency Support Offices}

Atlanta Support Office

James R. Powell, Director

U.S. Department of Energy

730 Peachtree Street, N.E., Suite 876

Atlanta, GA 30308-1212

(404) 347-2888

Fax: (404) 347-3098
Boston Support Office

Hugh Saussy, Jr., Director

U.S. Department of Energy

1 Congress Street, Suite 1101

Boston, MA 02114

(617) 565-9710

Fax: (617) 565-9723

\section{Chicago Support Office}

James E. Alexander, Acting Director

U.S. Department of Energy

1 South Wacker Drive, Suite 2380

Chicago, IL 60606

(312) 886-8575

Fax: (312) 886-8561

Denver Support Office

William Becker, Director

U.S. Department of Energy

1617 Cole Boulevard

Golden, CO 80401

(303) 275-4801

Fax: (303) 275-4830

Philadelphia Support Office

Charles F. Baxter, Director

U.S. Department of Energy

1880 JFK Boulevard, Suite 501

Philadelphia, PA 19102

(215) 656-6954

Fax: (215) 656-6981

\section{Seattle Support Office}

Kathleen M. Vega, Director

U.S. Department of Energy

800 Fifth Avenue, Suite 3950

Seattle, WA 98104

(206) 553-1132

Fax: (206) 553-2200

65

\section{Office of Budget Planning and Customer Service John Atcheson, Acting Director EE-70, Room 6A-045, Forrestal Building Washington, DC 20585 \\ (202) 586-6238}

Provides analysis, information, and decision support to all levels of EE management for planning, budget formulation and defense; and provides communications, outreach and customer service to EE corporate customers to facilitate the meeting of EE corporate goals. Carries out functions in three major areas: budget planning, customer service and analysis. Budget planning includes development of corporate goals, multi-year planning, corporate formulation of budget requests and defense of those requests. Customer service includes management and execution of corporate level communications, information transfer and outreach to customers and 
stakeholders, and meeting customer needs and expectations through improved customer service. Analysis includes conduct of analysis that supports and enhances budget planning and customer service functions such as strategic information gathering, policy analysis, program benefits assessment and performance measurement and assessment.

\section{6}

\author{
Office of Federal Energy Management \\ Programs \\ John Archibald, Acting Director \\ EE-90, Room 5F-064, Forrestal Building \\ Washington, DC 20585 \\ (202) 586-5772
}

Plans and manages energy conservation for the Federal government. Specific objectives include reducing total energy consumption by the Federal government; increasing efficiencies and reducing costs; altering the fuel mix within the Federal consumption total; enhancing the use of renewable energy fuels; and reducing dependence on imported fuels. The program attempts to set an example for the Nation by transferring the Federal energy experience to State and local governments and, ultimately, the private sector. Develops and implements a comprehensive schedule for achieving legislative milestones and plans for effecting the required transfer of information. A long-term benefit of these activities is building an infrastructure in Federal agencies that institutionalizes energy efficiency as a good business practice.

\section{7}

\author{
Golden Field Office \\ Frank Stewart, Manager \\ U.S. Department of Energy \\ 1617 Cole Boulevard \\ Golden, CO 30401 \\ (303) 275-4778
}

Fax: (303) $275-4788$

Responsible for the management and administration of the DOE prime contract for the operation of the National Renewable Energy Laboratory (NREL). Through partnerships with DOE laboratories and the private sector, the Office carries out initiatives to meet requirements of the Energy Policy Act of 1992 as well as other technology deployment initiatives. Provides administrative support for the DOE Regional Support Offices.

\section{8}

Office of the Assistant Secretary for Environment, Safety and Health (HR) Tara J. O'Toole, Assistant Secretary EH-1, Room 7A-097, Forrestal Building Washington, DC 20585 (202) 586-6151

Assures conformance of the Department's activities with all applicable laws and requirements governing protection of the environment as well as the safety and health of the public and the workers at Department of Energy facilities; conducts scientific and technical programs to enhance the Department's ability to protect the health and safety of workers and the public; and ensures adequate training programs for the Department's contractor employees so they understand work related hazards and their responsibilities to protect themselves, the public, and the environment.

Office of the Deputy Assistant Secretary for Oversight

Glenn S. Podonsky, Deputy Assistant

Secretary

EH-2, Room 4011, 270CC

Germantown, MD 20874

(301) 903-3777

Evaluates and reports on the status of Departmental environment, safety (including nuclear safety), health, and safeguards and security policies and programs. Sets the direction for evaluating hazards and anticipating high-risk activities through independent oversight of policy and program effectiveness in these areas; facilitates the identification of and response (both internal and external) to policy issues, such as the Cohen amendment, trends, and directions; and identifies needs and supports development of inspection and assessment methods and technologies.

70

$$
\begin{aligned}
& \text { Office of Security Evaluations } \\
& \text { Barbara R. Stone, Director } \\
& \text { EH-21, Room C-305 } \\
& 19901 \text { Germantown Road } \\
& \text { Germantown, MD } 20874 \\
& \text { (301) } 903-5895
\end{aligned}
$$

Evaluates and reports on the status of Departmental safeguards and security policies and programs. Conducts inspections to determine the effectiveness of safeguards and security policies and programs; identifies and analyzes safeguards and security policy issues, trends and directions; and develops inspection and assessment methods and technologies.

\author{
Office of Environment, Safety and Health \\ Evaluations \\ Silas D. Stadler, Director \\ $\mathrm{EH}-22$, Room 5019, 270CC \\ Germantown, MD 20874 \\ (301) 903-5392
}

Evaluates and reports on the status of Departmental environment, safety, and health policies and programs. Conducts inspections to determine the effectiveness of environment, safety, and health policies and programs; identifies and analyzes 
environment, safety, and health policy issues, trends, and directions; and develops inspection and assessment methods and technologies.

72 Office of Oversight Analysis and Planning Support

Rebecca F. Smith, Director

EH-23, Room 4007, $270 \mathrm{CC}$

Germantown, MD 20874

(301) 903-5791

Coordinates and integrates the varied evaluation and reporting activities under the cognizance of the Deputy Assistant Secretary for Oversight. Provides the interface and liaison for overall oversight activities among internal Departmental elements and external organizations. Establishes and implements the training and certification programs for Office personnel.

73 Office of Environment, Safety and Health Residents

(Vacant), Director

EH-24, Room 4035, 270CC

Germantown, MD 20874

(301) 903-3548

Provides day-to-day on-site monitoring of environment, safety, health, and safeguards and security policies and programs at key Department of Energy sites to determine the Department's line management's effectiveness in protecting workers, the public, the environment, and national security interests. The individual site Representatives observe and assess Departmental programs at assigned sites and maintain liaison with other Departmental elements.

Office of the Deputy Assistant Secretary for Nuclear and Facility Safety

Orin F. Pearson, Deputy Assistant Secretary EH-3, Room 7A-121, Forrestal Building

Washington, DC 20585

(202) 586-2407

Provides policy and technical assistance in the areas of nuclear and facility safety. This is carried out through an integrated program involving analysis of facility operations, assistance to line managers for their implementation of major nuclear safety assurance programs, and the development of policies and standards.

75 Office of Nuclear Safety Policy and Standards

Richard L. Black, Director

$\mathrm{EH}-31$, Room 2021, CXXI-3

Germantown, MD 20874

(301) 903-3465
Establishes clear DOE nuclear safety expectations through management of the development, interpretation, and promulgation of coherent and comprehensive policies, requirements, guidance, and technical standards for protection of the health and safety of workers, the public, and the environment. The Office is the central point within the Department for liaison with other agencies, committees, national and international governmental bodies, and industry groups on standards-making activities affecting safety. The Office assists line management in the identification and implementation of appropriate standards to assure adequate protection.

76

\author{
Office of Facility Safety Analysis \\ Sarbeswar Acharya, Director \\ $\mathrm{EH}-32$, Room 324, CXXI-3 \\ Germantown, MD 20874 \\ (301) 903-1341
}

Acts as a center of expertise within the $\mathrm{EH}$ for nuclear and non-nuclear facility safety analyses and provides assistance to the Department's line programs in their analysis of hazards and risks arising from facilities in all phases of facility life cycle li.e., design, construction, operation, and decontamination and decommissioning). Reviews or conducts safety analyses for specific facilities, sites, projects or issues as requested by other elements of $\mathrm{EH}$. The Office also helps develop and promote improved methodologies and programs for safety and risk analyses; manages safety programs for the DOE owned dams; provides co-ordinating functions to Interagency Nuclear Safety Review Panel on behalf of the Department; and performs special assignments by Secretarial initiatives, e.g., environmental, safety, and health vulnerability assessments.

\section{Office of Operating Experience Analysis \\ Thomas A. Rollow, Director \\ EH-33, Room 5H-021, Forrestal Building \\ Washington, DC 20585 \\ (202) 586-7449}

Evaluates operations and identifies environment, safety and health performance trends, and feeds back lessons learned. Evaluates facility current events and conditions, analyzes long-term trends and patterns, identifies generic safety issues, and conducts special studies. Has cognizance of the Department's Occurrence Reporting System to ensure that all information is reported properly, evaluated, acted upon, and appropriately communicated to line management. 
Office of Engineering Assistance and Site Interface

Mark H. Williams, Director

EH-34, Room 322, CXXI-3

Germantown, MD 20874

(301) 903-1743

Provides and coordinates technical support program to ensure the safety of the workers and the public through an integrated program involving analysis of facility operations, effective liaison with site managers, assistance to line managers for the implementation and enhancement of major nuclear safety assurance programs, and the use of feedback from the Department's Operations Offices. Interfaces with the major nuclear sites to assist line management in safety assurance programmatic activities.

79

\author{
Office of the Deputy Assistant Secretary for \\ Environment \\ Raymond P. Berube, Deputy Assistant \\ Secretary \\ EH-4, Room 7A-075, Forrestal Building \\ Washington, DC 20585 \\ (202) $586-5680$
}

Promotes environmentally sound practices throughout the Department and supports program and field offices in achieving this end by providing technical assistance in meeting current and oncoming compliance issues. Provides Departmentwide leadership in improving compliance and averting oncoming environmental protection and compliance problems and assistance to DOE program and field offices in understanding and implementing environmental requirements as well as resolving current and oncoming compliance issues. Establishes Departmentwide policies and guidance for environmental protection and compliance and promotes national environmental goals through effective National Environmental Policy Act compliance.

80

\author{
Office of Environmental Policy and \\ Assistance \\ Raymond F. Pelletier, Director \\ EH-41, Room 3G-092, Forrestal Building \\ Washington, DC 20585 \\ (202) 586-8505
}

Develops Departmentwide environmental protection policies and strategies for protecting the public and the environment and for attaining and maintaining environmental compliance. Coordinates and develops the Department's position on emerging environmental requirements.

\author{
Compliance Assistance Division \\ Vivian Bowie, Acting Director \\ EH-411, Room 3G-089, Forrestal Building \\ Washington, DC 20585 \\ (202) 586-1771
}

Establishes and promotes environmental protection policies and strategies. Provides assistance in implementation of environmental compliance requirements and policies, and the resolution of complex-wide and significant site specific compliance issues.

\section{Air, Water, and Radiation Division Andrew Wallo, Director EH-412, Room GA-098, Forrestal Building Washington, DC 20585 (202) 586-4996}

Develops policies, regulations, standards, and guidance to support understanding and implementation of air, water, and radiation related environmental protection laws, regulations, and standards. Coordinates and develops the Department position on emerging air, water, and radiation environmental protection requirements including the application of environmental management systems approach to DOE facilities.

83
Resource Conservation and Recovery
Act/Comprehensive Environmental Response Compensation and Liability Act (RCRA/CERCLA) Division
Thomas T. Traceski, Director EH-413, Room GA-076, Forrestal Building Washington, DC 20585
(202) $586-2481$

Develops policies, standards, and guidance to ensure understanding of hazardous waste management, toxic substance reporting, natural resource trusteeship and hazardous substance release response laws, regulations, and standards. Formulates methods for streamlining/accelerating Departmental environmental restoration and waste management efforts compliant with statutory and regulatory environmental requirements. Coordinates and develops the Department's position on emerging hazardous substance management requirements.

84 Office of National Energy Policy Act (NEPA) Policy and Assistance Carol M. Borgstrom, Director EH-42, Room 3E-080, Forrestal Building Washington, DC 20585 (202) $586-4600$

Assures that the Department's proposed actions comply with the requirements of NEPA and related environmental review requirements. Serves as DOE's 
focal point for NEPA expertise and related activities in all program areas, providing project-specific NEPA technical assistance and review to ensure the adequacy of NEPA documentation. Develops written Orders, policies, and guidance documents that cover NEPA and related environmental review requirements and implementation.

\section{5}

\author{
Waste Activities Division \\ Stanley Lichtman, Director \\ EH-421, Room 3E-080, Forrestal Building \\ Washington, DC 20585 \\ (202) 586-4610
}

Assures that the Department's proposed projects and programs involving radioactive, hazardous, and nonhazardous wastes comply with the requirements of NEPA and other related requirements before their implementation. Provides dedicated environmental support to the Office of Civilian Radioactive Waste Management.

\section{Project Activities Division \\ Robert H. Strickler, Director \\ EH-422, Room GB-096B, Forrestal Building \\ Washington, DC 20585 \\ (202) 586-2410}

Assures that DOE programs and new projects comply with NEPA and other environmental review requirements that are necessary prior to project implementation through generic guidance as well as project assistance and independent review activities.

87 Office of the Deputy Assistant Secretary for Worker Health and Safety

Joseph E. Fitzgerald, Jr., Deputy Assistant Secretary

EH-5, Room 5129, 270CC

Germantown, MD 20874

(301) 903-5532

Develops, manages, and directs programs for protecting the health and safety of workers at all of the Department's facilities. Develops, coordinates, and promulgates DOE policy, orders, and standards related to occupational safety and health and assists DOE's line management in implementating a broad range of programs to enhance worker and public health and safety.

\section{8}

\author{
Office of Occupational Safety and Health \\ Policy \\ (Vacant), Director \\ EH-51, Room 5093, 270CC \\ Germantown, MD 20874 \\ (301) $903-4343$
}

Establishes policies, programs, standards, and training focused on protection of DOE and contractor personnel from exposure to occupational injury and illness, including providing direction to DOE program, field, and project offices; provides technical assistance in the areas of industrial and construction safety, safety engineering, and industrial hygiene.

89

\author{
Office of Worker Protection Programs and \\ Hazards Management \\ C. Rick Jones, Director \\ EH-52, Room 5096, 270CC \\ Germantown, MD 20585 \\ (301) 903-6061
}

Establishes and assists in the implementation of programs for the protection of workers from hazards in the work place. Maintains direct partnership with headquarters and field programs to develop integrated, comprehensive, and field tested policy, standards, and guidance for programs to enhance worker protection. Establishes and assists in the implementation of the Department's Worker Radiation Protection Program. Manages the DOE worker hazards management program and maintains liaison with national and international standards setting organizations.

90

\author{
Office of Field Support \\ Robert W. Barber, Director \\ EH-53, Room 5042, 270CC \\ Germantown, MD 20874 \\ (301) 903-3477
}

Provides integrated multi-disciplinary support to DOE line management, field operations, and contractor organizations for the express purpose of achieving excellence in worker safety and health. Draws on the resources within $\mathrm{EH}$ to provide this assistance, in addition to providing specific expertise in the areas of chemical hazards, high explosives, risk assessment, facility operations, and aviation operation and maintenance.

91 Office of the Deputy Assistant Secretary for Health Studies

Paul J. Seligman, Deputy Assistant

Secretary

EH-6, Room 4119, 270CC

Germantown, MD 20874

(301) 903-5926

Promotes worker and public health through leadership in domestic and international health studies and occupational medicine. Promotes the health and safety of DOE workers and the communities surrounding DOE sites by developing policy and managing programs that focus on obtaining, analyzing, and communicating medical information and by supporting epidemiologic studies related to the prevention of illness and injury. Implements programs to communicate exposure and 
medical surveillance information to DOE management, DOE contractor employees, labor representatives, and the public. Supports an international program of epidemiologic and dosimetry studies focusing on the health impacts of populations exposed to ionizing radiation and non-ionizing radiation.

92

\author{
Office of Occupational Medicine and \\ Medical Surveillance \\ George R. Gebus, Director \\ EH-61, Room 4048, $270 \mathrm{CC}$ \\ Germantown, MD 20874 \\ (301) 903-7385
}

Provides policies, standards, and technical assistance to site occupational medicine programs. Supports DOE line managers in meeting their responsibilities for assuring the provision of quality occupational medicine programs which include monitoring the site work force for occupationally-related health effects; assuring that workers are fit for duty; helping to accommodate disabilities; minimizing time lost due to injury or illness; providing emergency medical response; and assisting employees in overcoming health problems affecting job performance. Supports a prevention-oriented health surveillance program that routinely collects health information in a form that allows analysis which links hazard exposures to health outcomes. Funds projects aimed at identifying occupational health effects occurring among former DOE workers.

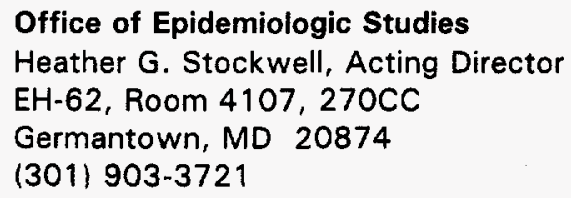

Uses epidemiologic studies to examine possible linkages between exposures or conditions brought about by DOE activities and adverse health effects among groups of workers and surrounding communities. Manages an epidemiologic research program in collaboration with Federal and State public health agencies. Disseminates study results on human health effects to workers and the public.

\section{Office of International Health Programs \\ Frank C. Hawkins, Director \\ EH-63, Room 4079, 270CC \\ Germantown, MD 20874 \\ (301) 903-2476}

Provides information and management services that expand the knowledge of health effects of radiation and related environmental hazards. Directs and/or participates in epidemiologic studies on the health of groups who have been exposed to ionizing and nonionizing radiation outside the United States, including
Japanese atomic bomb survivors, German uranium miners, Chernobyl plant workers and the exposed population, the Ukrainian and Belarus population, and the population residing near Palomares, Spain; as well as developing new projects to investigate the health effects of nuclear weapons production in the former Soviet Union. Provides health surveillance and medical care for the exposed population in the Marshall Islands.

95 Office of the Deputy Assistant Secretary for Planning and Administration Geoffrey J. Judge, Deputy Assistant Secretary EH-7, Room GB-096, Forrestal Building Washington, DC 20585 (202) $586-4704$

Provides the leadership, centralized management, and direction for EH's planning, budgeting, financial, human resources, information management systems, business performance systems, all personnel support activities including employee development and training, executive succession, affirmative action and program execution processes.

\section{6}

Office of Budget and Administration
Lesley A. Gasperow, Director
EH-71, Room $4125,270 \mathrm{CC}$
Germantown, MD 20874
(301) 903-5577

Provides financial and administrative assistance to the Assistant Secretary for $E H$, including the preparation and execution of the Office's budget, funds control and accounting activities, procurement and contracting support, preparation of management studies, and provision of personnel and management support services.

\section{Office of Information Management \\ R. Stephen Scott, Director \\ EH-72, Room 110, CXXI-3 \\ Germantown, MD 20874 \\ (301) 903-3033}

Develops and manages a centralized inventory, integrates and facilitates access to and use of all data and information sources necessary for conducting the programs and activities of $\mathrm{EH}$. Provides and manages the personnel, hardware, software and connectivity that comprise the ES\&H technical information services which allows for access to data and information and enables communication through $\mathrm{EH}$, between $\mathrm{EH}$ and other DOE offices, between $\mathrm{EH}$ and other external systems, and between EH and its contractors, stakeholders and the public. 
Office of Business Performance Systems Francis E. Tooper, Director EH-73, Room 1G-080, Forrestal Building Washington, DC 20585

(202) 586-1772

Improves DOE environment, safety and health performance by developing and implementing budget and planning processes focused on identifying needed environment, safety and health program activities; setting priorities based on risk; effective allocation of resources; and improved accountability for environment, safety and health business performance.

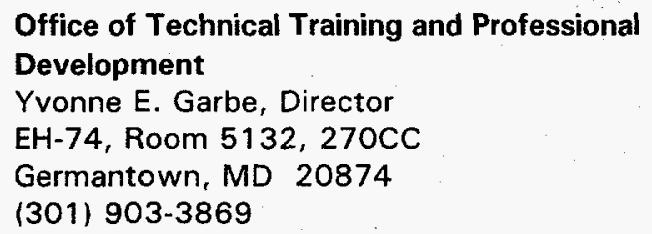

Assures that the Department and its contractors are properly trained in accordance with current DOE policy, procedures and professional standards and are technically qualified to carry out the Department's environment, safety and health, and safeguards and security missions in a safe, efficient and effective manner.

100

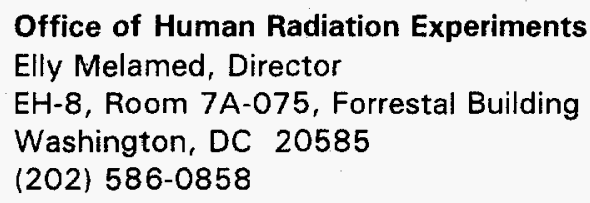

Office of Human Radiation Experiments Elly Melamed, Director EH-8, Room 7A-075, Forrestal Building Washington, DC 20585

(202) $586-0858$

Carries out continuing efforts under the Department's openness initiative to provide information and records to the public about historical human radiation experiments and related matters, responds to individual public inquiries about human radiation experiments, and supports the implementation of the recommendations of the President's Advisory Committee on Human Radiation Experiments.

101 Office of Enforcement and Investigation R. Keith Christopher, Director EH-10, Room 311, CXXI-3 Germantown, MD 20874 (301) $903-0100$

Implements the Department's statutory nuclear safety enforcement program as required under the Price-Anderson Amendments Act of 1988. investigates potential violations of nuclear safety requirements, and issues civil penalties, when warranted. Investigates criminal violations of DOE's nuclear safety rules and refers matters to the U.S. Department of Justice, when appropriate.

\section{Energy Information Administration (EI)}

102

\author{
Office of the Administrator \\ Jay E. Hakes, Administrator \\ El-1, Room 2H-027, Forrestal Building \\ Washington, DC 20585 \\ (202) $586-4361$
}

Responsible for the management of the Energy Information Administration (EIA) which collects, evaluates, and disseminates data pertaining to energy resources, reserves, production, and demand.

103 Office of Oil and Gas

Kenneth A. Vagts, Director

El-40, Room 2H-058, Forrestal Building

Washington, DC 20585

(202) $586-6401$

Designs, develops, and maintains oil and gas statistical data and current and short-term analytical and forecasting information systems. Performs data collection, quality control, processing analyses, short-term forecasting, and report preparation activities associated with these energy sources.

\section{Petroleum Supply Division}

John Cook, Acting Director

EI-42, Room 2G-051, Forrestal Building

Washington, DC 20585

(202) 586-5214

Designs, develops, and maintains statistical and short-term forecasting information systems for crude oil and refined petroleum products. Performs data collection, processing, current analyses, and short-term forecasting, and report preparation activities associated with the availability of crude oil and refined petroleum products.

\section{Petroleum Marketing Division}

John S. Cook, Director

El-43, Room 2G-051, Forrestal Building

Washington, DC 20585

(202) $586-5214$

Designs, develops, and maintains crude oil and refined petroleum product price and marketing statistical information systems. Performs data collection, quality control, processing, current and short-term analyses and forecasting, and report preparation activities associated with crude oil and petroleum products markets. 
Reserves and Natural Gas Division

Joan E. Heinkel, Director

El-44, Room BE-054, Forrestal Building

Washington, DC 20585

(202) 586-6090

Designs, develops, and maintains statistical and short-term forecasting information systems for domestic oil and gas reserves and production, and on the natural gas industry. Performs data collection, processing, analyses, short-term forecasting, and report preparation activities associated with oil and gas reserves and production, and all aspects of natural gas markets.

107 Office of Coal, Nuclear, Electric and

Alternate Fuels

John C. Geidl, Director

El-50, Room 6070

950 L'Enfant Plaza, S.W.

Washington, DC 20585

(202) $426-1200$

Designs, develops, and maintains coal, nuclear, electric, and alternate fuels statistical and short-term forecasting information systems.

\section{Survey Management Division}

Howard L. Walton, Director

El-52, Room 6033

950 L'Enfant Plaza, S.W.

Washington, DC 20585

(202) 426-1233

Designs, develops, and maintains coal, nuclear, electric and alternative fuels data collection surveys. Prepares publications containing these data and provides information for the National Energy Modeling System and other EIA forecasting models. Provides statistical interpretation, analyses, and support to other DOE offices, Federal agencies, Congress, and the public for these energy sources.

\section{Analysis and Systems Division}

Robert M. Schnapp, Director

El-53, Room 6073

950 L'Enfant Plaza, S.W.

Washington, DC 20585

(202) 426-1211

Designs, develops, and maintains statistical information and short-term forecasting systems related to coal, nuclear, electric and alternate fuels. Assesses existing and potential resources and reserves, analyzes historical trends, produces forecasts for the short-term, performs quality control, and improves and maintains systems for data collection and analyses.
110 Office of Energy Markets and End Use Webster C. Kilgore, Director El-60, Room 2G-090, Forrestal Building Washington, DC 20585

(202) 586-1617

Conducts analyses and provides short-term forecasts of energy markets. Monitors energy markets and maintains a contingency planning capability for use in case of emergency. Maintains integrated energy statistics and surveys energy consumption trends in each sector of the economy. Performs financial analyses of energy companies and tracks their investment trends. Designs, develops, and maintains energy statistical and short-term forecasting information systems concerning consumption and subjects which cut across energy sources.

\section{Energy Markets and Contingency}

Information Division

Mark Rodekohr, Director

El-62, Room 2G-060, Forrestal Building

Washington, DC 20585

(202) $586-1130$

Performs analyses and short-term forecasting of world oil markets and energy demand patterns and prices and assesses the principal factors that affect these patterns. Acts as the center for the collection, analyses, and interpretation of enterprise-level financial and operating data within the EIA. Prepares and implements a program for the collection, evaluation, processing, and presentation of international energy data.

\section{End Use and Integrated Statistics Division}

Lynda T. Carlson, Director

EI-63, Room 2F-065, Forrestal Building

Washington, DC 20585

(202) $586-1112$

Designs, develops, tests, maintains, and documents energy consumption surveys and information systems which provide accurate and consistent data on energy end use in the residential, commercial, transportation, and industrial sectors. Provides monthly and annual integrated energy statistics for all sources of energy. Develops historical and current preliminary estimates of energy supply and disposition balances and energy prices and expenditures data and interprets trends and events.

113 Office of Statistical Standards

Yvonne M. Bishop, Director

El-70, Room 7029

950 L'Enfant Plaza, S.W.

Washington, DC 20585

(202) 426-1068 
Develops statistical policies for the EIA and provides technical assistance in survey design and statistical analyses. Assesses the quality and relevance of energy information and the processes used to collect, analyze, and forecast it. Coordinates ElA's statistical programs with the Office of Management and Budget, other Federal agencies, and academic and professional groups.

\section{4}

\author{
Quality Assurance Division \\ Douglas R. Hale, Director \\ El-72, Room 7029 \\ 950 L'Enfant Plaza, S.W. \\ Washington, DC 20585 \\ (202) 426-1074
}

Conducts data and model evaluations to assess the basic soundness of EIA's data systems and models; conducts data and model evaluations to assess the quality, relevance, and soundness of published statistics and the economic foundations of models and their mathematical and statistical properties; analyzes data systems and models and recommends improvements; compares EIA's data to other available data and, where applicable, identifies inconsistencies, the possible reasons, and solutions to address any problems; and conducts applied research in areas pertinent to the quality needs of EIA; and identifies needs for new standards or revisions to old standards and participates in their development and implementation.

\section{Standards and Services Division John Gross, Director El-73, Room 7031 \\ 950 L'Enfant Plaza, S.W. Washington, DC 20585 (202) 426-1071}

Writes standards for EIA's data collection, processing, publication, analysis and forecasting activities; identifies need for changes to existing standards and prepares necessary standards and related materials; develops supplementary materials to assist EIA in standards-related areas; manages the public-use forms clearance process for DOE's energy information collections; directs the energy information burden control program; maintains a glossary of energy and energy-related terms and definitions for use by EIA; conducts various programs to assess standards compliance and recommends actions to achieve compliance; and maintains EIA's Data Resources Directory (DRD), a metadata system with descriptions of forms, models, systems, and energy-related terms and definitions.
116 Office of Integrated Analysis and Forecasting

Mary J. Hutzler, Director

El-80, Room 2F-081, Forrestal Building

Washington, DC 20585

(202) $586-2222$

Conducts forward-looking analyses and develops forecasts of alternative energy futures. Develops, applies, and maintains the National Energy Modeling System (NEMS) and other modeling systems needed to analyze and illuminate the complex interactions of the demand, conversion, and supply for all energy sources and their economic and environmental impacts. Performs analytical studies of integrated energy markets and how they are affected by alternative energy policies and other parameters. Prepares mid- and long-term forecasts of energy markets, penetration of new technologies, and changes in energy, environmental, and macroeconomic policies and international developments. Publishes regular reports and special reports as requested. Coordinates with other EIA offices to maintain data systems needed for inputs to integrated analysis forecasting models and analyses. Conducts the voluntary reporting program on Greenhouse Gas Emissions and produces related reports.

\section{Energy Demand and Integration Division Arthur T. Andersen, Director El-81, Room 2F-081, Forrestal Building Washington, DC 20585 (202) $586-1441$}

Conducts forward-looking analyses of energy demand; generates mid- and long-term forecasts of energy demand; and develops the demand components of the NEMS and other models dealing with the demand for energy services and energy consumption. Produces annual forecasting reports on both domestic and international markets.

\section{Energy Supply and Conversion Division Scott Sitzer, Director El-82, Room 2H-034, Forrestal Building Washington, DC 20585 (202) $586-2308$}

Conducts forward-looking analyses of energy supply and conversion activities, including electricity and refining; generates mid- and long-term forecasts of energy supply and conversion; and develops the energy supply and conversion components for NEMS and other models dealing with production, distribution, and conversion of all energy sources. 
Office of the Assistant Secretary for Environmental Management (EM)

119 Office of the Deputy Assistant Secretary for Waste Management

Stephen P. Cowan, Deputy Assistant

Secretary

EM-30, Room 5B-040, Forrestal Building

Washington, DC 20585

(202) 586-0370

Responsible for all DOE facilities, operations, and sites that are used for the storage, treatment, or disposal of radioactive, hazardous waste materials that have been packaged and labeled, or used exclusively for long-term storage of DOE waste materials. Excepted are facilities, operations, or sites under the direction of the DOE Office of Civilian Radioactive Waste Management.

\section{0}

\author{
Office of Eastern Operations \\ Ralph Erickson, Director \\ EM-32, Room 342 \\ 12800 Middlebrook Road \\ Germantown, MD 20874 \\ (301) 903-7184
}

Provides leadership, policy and program/budget direction and guidance, resources, strategic analyses, integration, evaluation, and representation and advocacy of waste management program activities within the purview of the Savannah River and Ohio Operations Offices. Responsible for programs involving waste management at DOE sites including treatment, storage, transportation, and disposal of high-level, transuranic, and low-level radioactive waste; hazardous waste; mixed radioactive and hazardous waste; and sanitary waste compliance with applicable internal and external program and environmental protection and safety and health requirements.

\section{Office of Business Management}

Dick Blaney, Director

EM-33, Room 424

12800 Middlebrook Road

Germantown, MD 20874

(301) 903-7147

Responsible for the program's cost-effectiveness and efficiency, including management plans and procedures performance measurement; progress reporting; program cost reduction initiatives; business data analysis; work breakdown structure; technical, cost and schedule baselining and control; preparation of program information; total quality management; program formulation and execution; and contract administration.
122 Office of Central Operations

Mark Frei, Director

EM-34, Room 322

12800 Middlebrook Road

Germantown, MD 20874

(301) 903-7201

Provides leadership, policy and program/budget direction and guidance, resources, strategic analyses, integration, evaluation, and representation and advocacy of waste management program activities within the purview of Albuquerque, Chicago, Oak Ridge, and Oakland Operations Offices. Responsible for programs involving waste management at DOE site including treatment, storage, transportation, and disposal of high-level, transuranic, and low-level radioactive waste; hazardous waste; mixed radioactive and hazardous waste; and sanitary waste compliance with applicable internal and external program and environmental protection and safety and health requirements.

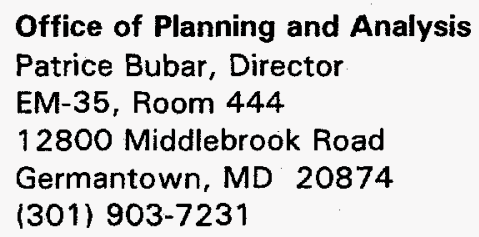

Responsible for the integration of activities that support policy development and program guidance for DOE waste management program including development, facilitation, and coordination of the overall strategic planning process for the Office of Waste Management; the coordination of major strategic initiatives and analyses; and support of States and compact regions on low-level radioactive waste disposal.

\section{4}

\author{
Office of Western Operation \\ James Turi, Director \\ EM-36, Room 465 \\ 12800 Middlebrook Road \\ Germantown, MD 20874 \\ (301) 903-7105
}

Provides leadership, policy and program/budget direction and guidance, resources, strategic analyses, integration, evaluation, and representation and advocacy of waste management program activities within the purview of Idaho and Nevada Operations Offices and the Carlsbad and Rocky Flats Field Offices. Responsible for programs involving waste management at DOE sites including treatment, storage, transportation, and disposal of high-level, transuranic, and low-level radioactive waste; hazardous waste; mixed radioactive and hazardous waste; and sanitary waste compliance with applicable internal and external program and 
environmental protection and safety and health requirements.

\section{5}

\author{
Office of Technical Services \\ James V. Antizzo, Director \\ EM-37, Room 304 \\ 12800 Middlebrook Road \\ Germantown, MD 20874 \\ (301) 903-7133
}

Responsible for providing program specific environment, safety and health regulatory guidance; providing technical advice and assistance; conducting regulatory and legislative analysis; and coordinating the Office of Waste Management's quality assurance and self-assessment activities to assure compliance with internal and external requirements.

\section{Office of Hanford Operations}

Maureen Hunemuller, Director

EM-38, Room 411

12800 Middlebrook Road

Germantown, MD 20874

(301) 903-7180

Provides leadership, policy and program/budget direction and guidance, resources, strategic analyses, integration, evaluation, and representation and advocacy of waste management program activities within the purview of Richland Operations Office. Responsible for programs involving waste management at DOE site including treatment, storage, transportation, and disposal of high-level, transuranic, and low-level radioactive waste; hazardous waste; mixed radioactive and hazardous waste; and sanitary waste compliance with applicable internal and external program and environmental protection and safety and health requirements. Provides policy direction and guidance for the high-level radioactive waste storage safety program at Hanford.

127 Office of the Deputy Assistant Secretary for Environmental Restoration

James M. Owendoff, Deputy Assistant Secretary

EM-40, Room 5B-050, Forrestal Building

Washington, DC 20585

(202) 586-6331

Manages programs to ensure that risks to human health and the environment posed by DOE's past operations at its nuclear facilities and sites are eliminated or reduced to prescribed, safe levels. Assesses and cleans up these sites and facilities contaminated with radioactive, hazardous, and mixed waste.
128

Office of Eastern Area Programs

John Lehr, Acting Director

EM-42, Room 2176

20400 Century Boulevard

Germantown, MD 20874

(301) 903-2328

Manages remedial actions at inactive sites and surplus DOE facilities and the decontamination and decommissioning programs implemented in the operations offices in Chicago, Oak Ridge, and Savannah River.

\section{9}

Office of Program Support, Environmental Restoration

William Wisenbaker, Jr., Director

EM-43, Room 2181

20400 Century Boulevard

Germantown, MD 20874

(301) 903-3124

Provides administrative, management, and financial support to line organizations that comprise the Office of Environmental Restoration.

\section{0}

\author{
Office of Northwestern Area Programs \\ Sally A. Robison, Director \\ EM-44, Room 2099 \\ 20400 Century Boulevard \\ Germantown, MD 20874 \\ (301) 903-3626
}

Provides direction and oversight of remedial actions at inactive sites and surplus DOE facilities and manages the decontamination and decommissioning programs implemented in the operations offices in Idaho, Richland, and San Francisco.

\section{1}

\author{
Office of Southwestern Area Programs \\ Ralph G. Lightner, Director \\ EM-45, Room 2153 \\ 20400 Century Boulevard \\ Germantown, MD 20874 \\ (301) 903-3850
}

Provides direction and oversight of remedial actions at inactive sites and surplus DOE facilities and manages the decontamination and decommissioning programs implemented in the operations offices in Albuquerque, New Mexico, and Nevada.

132 Office of the Deputy Assistant Secretary for Science and Technology

Clyde W. Frank, Deputy Assistant Secretary EM-50, Room 5A-014, Forrestal Building Washington, DC 20585

(202) 586-6382 
Gerald G. Boyd, Associate Deputy Assistant Secretary for Technology Development

EM-50, Room 1151

19901 Germantown Road

Germantown, MD 20874

(301) 903-7260

Carol J. Henry, Associate Deputy Assistant Secretary for Science/Risk Policy EM-50, Room 5A-031, Forrestal Building Washington, DC 20585 (202) 586-7150

Mark A. Gilbertson, Director EM-52, Room 5A-031, Forrestal Building Washington, DC 20585

(202) $586-5042$

Manages the environmental science program that bridges broad-based basic research with applied environmental technology development research. Environmental Management's risk management and priority setting activities are also managed in this office.

133

\author{
Office of Technology Systems \\ Carl O. Bauer, Director \\ EM-53, Room 1157 \\ 19901 Germantown Road \\ Germantown, MD 20874 \\ (301) 903-8621
}

Manages an applied research and development program to address DOE's major environmental problems. Referred to as "focus areas," these include mixed waste; radioactive tank waste; subsurface contamination; and decontamination and decommissioning. Other crosscutting programs that support these focus areas are also conducted: robotics; efficient separations; and characterization and monitors.

134

\author{
Office of Technology Integration \\ John M. Lankford, Director \\ EM-54, Room 1127 \\ 19901 Germantown Road \\ Germantown, MD 20874 \\ (301) 903-7924
}

Manages technology transfer activities to facilitate implementation of innovative technologies as well as other supporting activities such as cost benefit analyses, environmental safety and health, and information management.
Office of Energy Research (ER)

\section{Office of the Director}

Martha A. Krebs, Director

ER-1, Room 7B-058, Forrestal Building

Washington, DC 20585

(202) $586-5430$

Carries out a broad range of advisory, coordination, and program management activities related to energy research and development missions. Supports a broad spectrum of research in the basic energy sciences, high energy and nuclear physics, magnetic fusion energy, and biomedical and environmental sciences. Advises the Secretary on science and technology policy; assesses DOE's research and development programs for duplication or gaps; and serves as focal point for coordination with other agencies in science and technology.

136 Office of Environment, Safety and Health Technical Support

Charles Billups, Acting Director

ER-8, Room E-240

19901 Germantown Road

Germantown, MD 20585

(301) 903-4097

Plans, develops, manages, and implements a central energy research environmental protection, safety, and health protection (ES\&H) technical support program. The overall purpose and aim of this program is to ensure protection of the environment and the health and safety of the public, provide a safe and healthful work place, and protect Government property against accidental loss and damage.

\section{Office of Basic Energy Sciences}

Patricia M. Dehmer, Associate Director ER-10, Room J-304 19901 Germantown Road Germantown, MD 20585 (301) 903-3081

Manages a basic research program covering a broad spectrum of scientific disciplines, which produces scientific and technical knowledge needed to develop future energy technology options; supports research leading to new materials, processes, instruments, and techniques useful in energy technologies; explores advanced energy concepts not currently included within Departmental energy technology organizational components; contributes to the base of fundamental science in the United States; provides and safely operates national advanced research facilities. 
Material Sciences Division

Iran L. Thomas, Director

ER-13, Room J-317

19901 Germantown Road

Germantown, MD 20585

(301) 903-3427

Funds and administers Metallurgy and Ceramics Research programs in the preparation and study of properties of new materials for improvement and control of chemical composition and structure; controlling, predicting and changing mechanical, surface, and other physical properties; and controlling properties of engineering materials and the effects of radiation. Also funds and administers Solid State Physics and Materials Chemistry Research programs in superconductivity, neutron scattering, new materials preparation, experimental studies, and theoretical modeling of optical, thermal, electronic, magnetic, and other properties of solids, engineering physics, high temperature and surface properties of solids, mass transport, chemical structure, and engineering chemistry.

\section{Chemical Sciences Division}

Robert S. Marianelli, Director

ER-14, Room G-336

19901 Germantown Road

Germantown, MD 20585

(301) 903-5808

Funds and administers the programs of the most basic and long-range energy-related chemical sciences research areas (e.g., photochemistry, radiation chemistry, hot atom chemistry, chemical dynamics, theoretical chemistry, many types of spectroscopy, and the physics of ions, atoms and molecules). Funds and administers programs that emphasize research in areas of chemical sciences needed to lead and assist in the advancement of energy technologies (e.g., the chemistry of various types of coals; heterogeneous and homogeneous catalysis; chemical thermodynamics; actinide chemistry; chemical basics of converting carbohydrates to liquid and gaseous fuels; separation of fuel substances before and after use; analytical chemistry; and chemical engineering sciences, such as dynamics of fluidized bed combustion). Funds and operates major user facilities providing unique capabilities for researchers.

\section{Engineering and Geosciences Division}

William C. Luth, Director

ER-15, Room G-363

19901 Germantown Road

Germantown, MD 20585

(301) 903-5822

Supports the Department's central fundamental research activities in the engineering and geoscience disciplines conducted by universities, Federal laboratories, and industrial firms throughout the United States. In engineering research, emphasis is given to analysis, control, and improvement of systems for transport of heat and fluids and for materials processing. In geoscience research, emphasis is given to the geophysics and geochemistry of rock/fluid systems.

\section{Energy Biosciences Division}

Gregory L. Dilworth, Director

ER-17, Room G-358

19901 Germantown Road

Germantown, MD 20585

(301) 903-2873

Funds and administers research activities of the Energy Biosciences subprogram conducted in universities, National laboratories, nonprofit institutions, and industry. Funds fundamental research in plant and microbial sciences that will underpin new biotechnologies relating to energy matters. Coordinates research efforts in energy bioscience matters with those of other DOE elements through the Bioenergy Coordinating Committee.

\section{2}

\author{
Office of High Energy and Nuclear Physics \\ John R. O'Fallon, Acting Associate Director \\ ER-20, Room H-410 \\ 19901 Germantown Road \\ Germantown, MD 20585 \\ (301) 903-3713
}

Provides effective planning, funding, and management of the Department's High Energy Physics and Nuclear Physics Research programs. Assists the Director of ER in the establishment of research policies for these areas of basic sciences and funds meritorious research programs at Federal laboratories, universities, and industrial institutions. Provides scientific and technical knowledge for development of technology options and technology transfer of those projects which show high promise of becoming important as energy technologies. Develops and executes procedures to ensure that the Nation's high energy and nuclear physics facilities are operated efficiently and reliably to meet the research needs of the near future and to ensure that new or upgraded facilities are designed and constructed as needed for the future health and vitality of these fields. Pursues international collaboration in all phases of high energy and nuclear physics.

143 Office of High Energy and Nuclear Physics Robert M. Simon, Deputy Associate Director ER-21, Room H-408

19901 Germantown Road

Germantown, MD 20585

(301) 903-3713 
Funds and administers the DOE-sponsored research efforts in high energy and nuclear physics conducted in universities, Federal laboratories, and industrial organizations. Serves as Executive Agent for the U.S. High Energy Physics Program. Maintains liaison and coordinates the U.S. High Energy Physics program with those of other nations and assists in the formulation and administration of formal international agreements of collaboration with other nations. Funds and administers the Nuclear Physics Program conducted in universities and Federal laboratories in the areas of medium energy and heavy ion nuclear physics, nuclear theory, low energy nuclear research, nuclear data measurements, and compilation and evaluation of nuclear data.

\section{Office of Computational and Technology}

Research

David B. Nelson, Associate Director

ER-30, Room J-123

19901 Germantown Road

Germantown, MD 20585

(301) 903-7486

Ensures the broad range of research in the mathematical and computer science fields necessary to underpin all of the other energy sciences and manages an international data communications network which provides state-of-the-art supercomputing facilities for ER contractors in universities, industry, and DOE laboratories. Carries out DOE's role as lead Federal agency for the acceleration of supercomputer development.

\section{Office of Fusion Energy Sciences}

Nelia A. Davies, Associate Director

ER-50, Room J-204

19901 Germantown Road

Germantown, MD 20585

(301) 903-4941

Manages programs related to the development of the scientific and technological base for fusion energy; interprets policy guidance and suggests policy revisions; develops and evaluates program and budget strategies, priorities, and plans encompassing scientific and technical program content, goals, and objectives, including institutional plans. Pursues international collaborations in research and in new, large facilities which may be too costly for any one country.

\section{6}

International Programs Staff

Michael Roberts, Director

ER-52, Room J-225

19901 Germantown Road

Germantown, MD 20585

(301) 903-3068
Develops and implements policies, plans, and strategies, and formulates the goals and objectives of international collaborations. Directs overall activities for the development of major joint projects, including the four-party International Thermonuclear Experimental Reactor (ITER) activities and technical exchange programs.

\section{Technology Division \\ Milton D. Johnson, Acting Director \\ ER-53, Room J-204 \\ 19901 Germantown Road \\ Germantown, MD 20585 \\ (301) 903-3347}

Manages and provides technical direction for the U.S. International Thermonuclear Experimental Reactor (ITER) program, as well as managing the U.S. fusion base technology development program for near-term experimental needs. Develops the technologies needed to form, contain, heat, and sustain a reacting fusion plasma, including magnetic, heating, and fueling systems. Focuses on elements of fusion devices related to long-term waste issues, safety and environmental considerations, device reliability, tritium production and power extraction. Undertakes theoretical and small-scale experimental studies of fusion plasma phenomena and basic issues needed to predict thermonuclear plasma behavior in confinement experiments and future fusion power systems. Supports and assesses the development of promising improvements to plasma configurations, and develops new diagnostic techniques needed to study plasma phenomena in support of magnetic and inertial confinement systems. Focuses on key technology elements of fusion devices and elements related to materials development. Supports examinations of proposed structural materials, low activation materials, and diverter materials. Conducts reactor studies to model future fusion power systems, to identify issues, and to provide future program direction.

\section{Science Division}

John W. Willis, Director

ER-55, Room G-250

19901 Germantown Road

Germantown, MD 20585

(301) 903-4095

Manages a program of medium-to-large fusion research experiments operating at reactor level plasma parameters. Emphasizes the resolution of key physics issues which are critical to the continued development of improved magnetic confinement systems leading to a practical fusion energy source. 
149 Office of Health and Environmental Research Aristides A. Patrinos, Associate Director ER-70, Room G-165

19901 Germantown Road

Germantown, MD 20585

(301) 903-3251

Manages basic and applied research programs to achieve understanding of health and environmental effects associated with energy technologies and to advance technological solutions for major problems in biology, medicine, and environmental sciencerelated issues. Supports research conducted in the Department's National laboratories, as well as in the university and private sector, in atmospheric, marine, and terrestrial processes, including the linkage between the rise in greenhouse gases, e.g., carbon dioxide, and regional and global climate change; molecular and subcellular mechanisms underlying human somatic and genetic processes and their responses to environmental toxicants; nuclear medicine, structural biology, the human genome, measurement sciences and instrumentation; and other areas that require the unique capabilities of the DOE laboratory system.

150

\author{
Health Effects and Life Sciences Research \\ Division \\ Marvin E. Frazier, Acting Director \\ ER-72, Room G-155 \\ 19901 Germantown Road \\ Germantown, MD 20585 \\ (301) 903-5468
}

Conducts research in selected experimental animal, cellular, and molecular model systems for evaluating the potential adverse health effects, such as carcinogenesis and mutagenesis and developmental effects that could result from exposures to radiation and chemical agents relevant to DOE programs. Supports general life sciences research to provide the base of fundamental biological knowledge that is required for the effective study and interpretation of energy-related health effects. Supports the technology development and computational biology for mapping and sequencing the human genome and optimizing the Department's capability for conducting structural biology research.

\section{Medical Applications and Biophysical Research Division \\ Roland F. Hirch, Acting Director \\ ER-73, Room G-146 \\ 19901 Germantown Road \\ Germantown, MD 20585 \\ (301) 903-3213}

Conducts research on advanced radiation and chemical dosimetry techniques. Pursues instrumentation research and development to acquire improved analytical measurement technology. Supports radiological physics research to provide fundamental insights into the interaction of radiation with biological systems. Conducts medical research to develop new radioisotope and radiopharmaceutical applications for diagnosis and therapy, advanced imaging instrumentation, and new radiation treatment approaches. Supports molecular nuclear medicine research which brings the insights and technology from molecular biology to achieve advanced nuclear medicine methodology.

\section{Environmental Sciences Division Michelle S. Broido, Acting Director ER-74, Room G-156 19901 Germantown Road Germantown, MD 20585 (301) 903-3281}

Conducts research on environmental processes and effects to address the transport and transformation of energy-related pollutants through atmospheric, marine, and terrestrial ecosystems; ecosystem responses and the mechanisms that control them; advanced concepts for waste cleanup; processes involved in stratospheric ozone depletion; and the role of molecular biology in understanding the oceanic, terrestrial, and surface ecosystem responses. Conducts a carbon dioxide program to establish the quantitative links between the rise of greenhouse gases and global warming, including studies to understand ocean circulation and the exchange of $\mathrm{CO}_{2}$ between the open ocean and the atmosphere.

\section{3}

\author{
Office of the Assistant Secretary for Fossil \\ Energy (FE) \\ Patricia Fry Godley, Assistant Secretary \\ FE-1, Room 4G-084, Forrestal Building \\ Washington, DC 20585 \\ (202) 586-6660
}

Oversees the Department's programs to develop advanced coal, oil and natural gas technologies, carry out certain electricity and natural gas regulatory functions, and manage the Strategic Petroleum Reserve and the Naval Petroleum and Oil Shale Reserves.

154 Office of Coal and Power Systems

George Rudins, Deputy Assistant Secretary FE-20, Room 4G-052, Forrestal Building

Washington, DC 20585

(202) 586-1650

Directs the research and development of future generations of coal-based and natural gas-based power systems for the stationary electric power generation market; directs the development of processes for improving the environmental 
performance of coal-base energy systems and for converting coal into clean liquid and other fuel forms. Responsible for issuing Presidential permits for the construction, connection, operation, and maintenance of electric transmission lines which cross the U.S. international border, the authorization of exports of electricity to foreign countries, and other certifications required by the Power Plant and Industrial Fuel Use Act of 1978.

\section{5}

\author{
Office of Natural Gas and Petroleum \\ Technologies \\ (Vacant), Deputy Assistant Secretary \\ FE-30, Room 3E-028, Forrestal Building \\ Washington, DC 20585 \\ (202) $586-5600$
}

Directs DOE's programs to develop improved technologies to find, extract and process natural gas and crude oil with an emphasis on improving domestic production from difficult geologic formations. Responsible for developing new and more cost-effective environmental compliance methods and technologies for oil and natural gas operations. Carries out statutory requirements to authorize natural gas imports and exports and provides the Department's regulatory interface with other agencies regarding natural gas import and export policies.

\section{6}

\author{
Office of Strategic Petroleum Reserve \\ Richard D. Furiga, Deputy Assistant \\ Secretary \\ FE-40, Room 3G-024, Forrestal Building \\ Washington, DC 20585 \\ (202) 586-4410
}

Responsible for the Strategic Petroleum Reserve, the Nation's emergency crude oil stockpile. The Strategic Petroleum Reserve is a complex of underground salt dome storage facilities sited along the Texas-Louisiana Gulf Coast. The storage facilities are connected to both private and Government-owned commercial oil distribution facilities. Crude oil can be withdrawn from the Reserve upon Presidential order to counter an energy supply disruption.

157

\author{
Office of Naval Petroleum and Oil Shale \\ Reserves \\ Ernest Hunter, Deputy Assistant Secretary \\ FE-60, Room 3H-076, Forrestal Building \\ Washington, DC 20585 \\ (202) 586-4685
}

Manages the operations of the three commercial oil and natural gas fields that make up the Naval Petroleum Reserves; also oversees the Government's ownership of the three Federally-owned properties that comprise the Naval Oil Shale Reserves. The
Naval Petroleum Reserves include Elk Hills and Buena Vista Hills located near Bakersfield, CA, and the Teapot Dome field near Casper, WY. The three oil shale reserves are located in western Colorado and northeastern Utah.

\section{Office of Hearings and Appeals (HG)}

George B. Breznay, Director

HG-1, Room 7044

950 L'Enfant Plaza, S.W.

Washington, DC 20585

(202) 426-1566

Responsible for conducting hearings and issuing the initial decision of the Department with respect to any adjudicative proceedings which the Secretary may delegate, except those within the jurisdiction of the Federal Energy Regulatory Commission and the Board of Contract Appeals. The Board of Contract Appeals is an independent, separate component within the Office for rendering decisions pertaining to contract disputes and related issues. Jurisdiction of the Office of Hearings and Appeals encompasses complaints filed under the DOE Contractor Employee Protection Program, and Personnel Security Hearing and Review functions. Analyzes and decides appeals requesting review of any determination reached by any other official within the Department under the jurisdiction of the Secretary, including initial determinations under the Freedom of Information Act, the Privacy Act, the payments-equal-to-taxes (PETT) provisions of Nuclear Waste Policy Act of 1982, as amended, the special assessment provisions for the Uranium Enrichment Decontamination and Decommissioning Fund under the Energy Policy Act of 1992, the reimbursement of costs of remedial actions at active uranium or thorium processing sites under the Energy Policy Act of 1992, the emergency international oil allocation provisions of the Energy Policy and Conservation Act, and the Standby Mandatory Crude Oil and Product Allocation, Refinery Yield Control and Pricing Programs. Responsible for deciding Applications for Exception from the generally applicable requirements of a rule, regulation, or order of the Department. Develops and implements procedures under the Petroleum Overcharge Distribution and Restitution Act of 1986 for refunding oil overcharge funds obtained pursuant to Departmental consent orders, remedial orders, and court orders to injured parties. Analyzes Petitions for Special Redress seeking "extraordinary relief" apart from, or in addition to, any other remedy provided in the Department's enabling statutes. 
159

Office of Management Operations

Patricia G. Spencer, Director

HG-10, Room 1142

950 L'Enfant Plaza, S.W.

Washington, DC 20585

(202) 426-1441

Responsible for establishing and operating the filing systems and docket facilities in connection with all adjudications pending before the Office of Hearings and Appeals. Provides administrative support and general management assistance to other HG offices.

160

\author{
Management Information Division \\ Otto S. Reid, Director \\ HG-12, Room 1140 \\ 950 L'Enfant Plaza, S.W. \\ Washington, DC 20585 \\ (202) $426-1441$
}

Establishes and operates a management information system which contains a full history of all filings made in cases under consideration by the Office. Maintains an information retrieval and data system in connection with all adjudications.

\section{Docket and Publications Division \\ Marcia B. Carlson, Director \\ HG-13, Room 1162 \\ 950 L'Enfant Plaza, S.W. \\ Washington, DC 20585 \\ (202) 426-1400}

Receives, screens, logs, and controls all documents submitted to the Office in connection with pending cases. Maintains official DOE case history files for all matters in which the Office has rendered a decision. Certifies the record on appeal when a matter is appealed to the courts or to the Federal Energy Regulatory Commission. Operates a Public Reference Room through which the public is afforded access to filing, decisions, and other documents with respect to cases which are either pending or have been decided by the Office. Arranges for the publication and dissemination of all Decisions and Orders of the Office of Hearings and Appeals.

\section{Office of Legal Analysis}

Thomas O. Mann, Deputy Director

HG-20, Room 1131

950 L'Enfant Plaza, S.W.

Washington, DC 20585

(202) 426-1492

Performs legal research with respect to submissions filed with the Office and recommends the final decision which the Department should issue with respect to Appeals, Applications for Exception, and other proceedings that primarily focus upon legal issues. Develops a full administrative record by receiving documentary evidence, conducting adversarial hearings, and preparing detailed written determinations. Formulates the legal procedures and substantive standards for the various types of adjudicative proceedings within the jurisdiction of the Office of Hearings and Appeals. The legal aspects of the Department's decision must satisfy due process standards and withstand review by the courts. Those decisions establish precedent and legal guidance for key divisions of the Department and govern the manner in which these offices exercise their responsibilities and affect all levels of the energy industry. This Office provides legal support to the Director and to other offices in the Department on matters involving Office of Hearings and Appeals litigation and procedural regulations.

163

Office of Financial Analysis
Richard T. Tedrow, Director
HG-30, Room 7044
950 L'Enfant Plaza, S.W.
Washington, DC 20585
(202) $426-1564$

Analyzes submissions and recommends the decisions which the Office should issue with respect to those Appeals, Applications for Exception, Proposed Remedial Orders, refund petitions, and other submissions that involve complex financial issues. Develops a full administrative record by receiving documentary evidence, conducting hearings, and preparing detailed written determinations. The submission considered by this Office requires analysis of major corporate transactions, the structuring of detailed remedies for regulatory abuses, and the development and implementations of plans which assess the extent of injury and establish mechanisms to make monetary restitution for prior regulatory violations. Activities involve the selection and application of various methods of financial analysis and the use of sophisticated indices to measure the fiscal impact of Departmental programs on a wide variety of business and governmental entities throughout the Nation.

\section{4}

\author{
Office of Economic Analysis \\ Thomas L. Wieker, Director \\ HG-40, Room 1150 \\ 950 L'Enfant Plaza, S.W. \\ Washington, DC 20585 \\ (202) 426-1529
}

Analyzes submissions and recommends the decisions that the Office should issue with respect to those Appeals, Applications for Exception, and other requests that primarily focus upon economic issues. In reaching determinations on these applications, the Office develops a full administrative record by receiving documentary evidence, conducting adversarial hearings involving expert econometric 
testimony, and preparing detailed written determinations. Submissions considered by this Office require economic analysis of the activities of major corporations in order to assess the effects of those activities and to structure specific remedies for regulatory abuses. This Office performs analyses to develop appropriate economic structures for refunding petroleum overcharges to adversely affected parties. The resolution of these issues results in a substantial impact on various sectors of the economy, including refiners, major utilities, industrial and military installations, as well as on Federal, State, and local governmental entities in all regions of the United States. This Office also analyzes the benefit and burden on firms requesting relief from Energy Information Administration reporting requirements.

\section{Board of Contract Appeals}

E. Barclay Van Doren, Chairman HG-50, Room 1006, Webb Building 4040 N. Fairfax Drive Arlington, VA 22203

(703) $235-2700$

The Energy Board of Contract Appeals is an administrative tribunal established pursuant to the Contract Disputes Act of 1978. It independently hears and decides appeals by contractors from contracting officer decisions under rules of procedure published in 10 C.F.R. 1023, Subpart $A_{\text {, }}$ and rules implementing the Equal Access to Justice Act published in 10 C.F.R. 1023, Subpart C. Under authority granted by the Secretary, the Board also performs other quasi-judicial functions as the Energy Financial Assistance Appeals Board 110 C.F.R. 600.26 and 10 C.F.R. 1024l, the Energy Invention Licensing Appeals Board (10 C.F.R. 781-63), the Energy Patent Compensation Board (10 C.F.R. 780), and the Contract Adjustment Board (10 C.F.R. 1023, Subpart B); decides certain appeals filed by subcontractors of management and operating contractors; and provides hearings officers for environmental, Debt Collection Act, and employee salary offset proceedings. Board decisions are not reviewable by the Department; however, decisions rendered under the Contract Disputes Act may be appealed by either the contractor or the Department directly to the Court of Appeals for the Federal Circuit. The Board also serves as the board of contract appeals for the Nuclear Regulatory Commission.

\section{Office of Procurement and Assistance} Management

Richard H. Hopf, Deputy Assistant Secretary HR-5, Room 6B-162, Forrestal Building Washington, DC 20585

(202) 586-8613
Office of Policy

Luther Jay Tillman, Director

HR-51, Room 8H-023, Forrestal Building

Washington, DC 20585

(202) $586-8182$

Responds to questions related to DOE contracting rules and regulations.

\section{Office of Clearance and Support}

Robert E. Barnes, Acting Director

HR-52, Room 11-018, Forrestal Building

Washington, DC 20585

(202) 586-9065

Provides general information regarding submission of unsolicited proposals to DOE, answers requests for information concerning DOE Requests for Proposals, and answers questions related to doing business with DOE.

168 Office of Headquarters Procurement Operations

Scott, E. Sheffield, Acting Associate Deputy

Assistant Secretary

HR-56, Room 402,

1615 M Street, N.W.

Washington, DC 20585

(202) 634-4400

Serves as the central point of contact for Headquarters contracting needs.

\section{Office of the Executive Secretariat}

169 Freedom of Information and Privacy Act Division

Gayla D. Sessoms, Director

HR-73, Room 1G-051, Forrestal Building

Washington, DC 20585

(202) 586-5955

Handles requests for information under the jurisdiction of the Freedom of Information Act and the Privacy Act.

170 Printing and Graphics Division Energy Technology Visuals Collection (ETVC)

HR-84, Room BH-039, Forrestal Building

Washington, DC 20585

(202) 586-9796

ETVC, which dates from the 1977 inception of DOE, serves as a central repository for visual aids representing the Department's many research and development activities. The collection, maintained and operated by the Office of Administrative Services, contains high quality photographs of over 600 DOE-sponsored projects in such areas as fossil 
fuels, nuclear fission and fusion, solar energy, conservation, and environmental activities. Images are available as 8 " $\times 10^{\prime \prime}$ black and white prints, 8 " $x 10$ " color prints, and $35 \mathrm{~mm}$ color slides through the Graphics Branch. Each image requested from the collection is accompanied by a computer-generated data sheet containing caption and background information. An automated cataloging system is used by the ETVC staff to conduct online searches of the data base with respect to program, project, technology, and geographic location. ETVC supports DOE program personnel as well as other Federal, State and local agencies, and the private sector, upon approval, in preparing publications and presentations.

Office of Nuclear Energy, Science and Technology (NE)

171 Office of the Director

Terry R. Lash, Director

NE-1, Room 5A-143, Forrestal Building

Washington, DC 20585

(202) $586-6450$

Provides technical leadership to address critical domestic and international nuclear issues, contribute to energy supply diversity, and advance United States competitiveness and security by providing nuclear products and services that meet the needs of the United States and the world community in a safe, environmentally sound, and economical manner, and encourage public involvement in our programs and provide information to increase public knowledge.

172 Office of Resource Management

W. J. Colsh, Director

NE-10, Room D-427

19901 Germantown Road

Germantown, MD 20874-1290

(301) 903-3795

Provides financial management and other administrative support to Nuclear Energy, Science and Technology programs.

\section{Office of Planning and Analysis}

William D. Magwood, IV, Associate Director NE-20, Room 5A-143, Forrestal Building Washington, DC 20585 (202) 586-6630

Central responsibility for uranium inventories held by the Department and management of fuel cycle issues. Provides general support to nuclear engineering programs at U.S. universities. Coordinates outreach activities.
174

\author{
Office of International Nuclear Safety \\ Kristen Suokko, Associate Director \\ NE-30, Room 5A-157, Forrestal Building \\ Washington, DC 20585 \\ (202) 586-7313
}

Cooperates with others to improve the safety of nuclear activities internationally. Cooperates and coordinates with other Departmental offices and government agencies in the implementation of U.S. nonproliferation policy. In particular, works to enhance nuclear safety in the former Soviet Union and Eastern Europe and assists in the shutdown of plutonium production reactors. Also coordinates with other DOE offices, the Department of State, and the White House to open new markets for U.S. nuclear technology.

\section{Office of Facilities}

Robert G. Lange, Associate Director

NE-40, Room F-444

19901 Germantown Road

Germantown, MD 20874-1290

(301) 903-2915

Manages the design, construction, and operation of the NE test facilities and Office of Energy Research reactor and supporting facilities, assuring their safe, reliable, and environmentally sound operation and their cost-effectiveness. Manages the conduct of shutdown activities necessary to place unneeded facilities into an industrial and radiologically safe shutdown condition. Manages the supply of reactor fuel to university reactors, manages the conversion of university reactors from highly enriched uranium (HEU) fuel to low enriched uranium (LEU) fuel, and supports university reactor instrumentation and equipment upgrades. Provides technical guidance related to the environmental, safety, and health aspects of United States imports of LEU and HEU from Russia and other countries of the former Soviet Union. Leads Department effort to ensure transparency in the conversion of Russian HEU to LEU.

176

\author{
Office of Engineering and Technology \\ Development \\ Sterling M. Franks, Associate Director \\ NE-50, Room A-251A \\ 19901 Germantown Road \\ Germantown, MD 20874-1290 \\ (301) 903-3456
}

Supports maintenance of the light water reactor option for domestic electricity generation. Manages a variety of nuclear research and development activities. Provides compact, safe nuclear power systems and related technologies to the National Aeronautics and Space Administration, the national security community, and to other customers. 


\section{Naval Reactors}

Admiral Bruce DeMars, Director

NE-60, Room 3NO6

National Center 2

2521 Jefferson Davis Highway

Arlington, VA 22202

(703) 603-7321

In accordance with Section 309(a) of the DOE Organization Act, provides the U.S. Navy with safe, military-effective nuclear propulsion plans in keeping with the Nation's defense requirements, and ensures their continued safe and reliable operation.

\section{Office of Isotope Production and Distribution}

Owen W. Lowe, Associate Director

NE-70, Room B-432

19901 Germantown Road

Germantown, MD 20874-1290

(301) 903-5161

Directs all isotope production and distribution activities within DOE, ensuring a reliable supply of medical, research, and industrial isotopes consistent with customer needs.

\section{Assistant Secretary for Pọlicy and} International Affairs (PO)

Marc W. Chupka, Acting Assistant Secretary PO-1, Room 7C-034, Forrestal Building

Washington, DC 20585

(202) $586-5800$

Advises the Secretary, Deputy Secretary, and Under Secretary on all domestic and international policy issues. Formulates and develops national energy policy; conducts policy analyses; and strategic planning; and integrates Departmental policy, program, and budget goals in coordination with the offices of the Chief Financial Officer and the Assistant Secretary of the Office of Human Resources and Administration. Analyzes, develops and coordinates Departmental technology policy, environmental policy, and economic policy. Develops and leads the Department's bilateral and multilateral cooperation and investment and trade activities with other nations and international agencies.

180 Office of Strategic Planning, Budget and Program Evaluation

Sylvia McDonald Monlyn, Acting Director PO-4, Room 7B-044, Forrestal Building

Washington, DC 20585

(202) $586-4453$

Responsible for developing, implementing, and managing Departmentwide strategic and multiyear planning; and providing indepth technical and policy evaluation of the Department's program and budget priorities to ensure conformance with such plans, policies, and strategies.

181 Office of the Deputy Assistant Secretary for Materials-Asset Management and National Security Policy Analysis

Robert Alvarez, Deputy Assistant Secretary PO-5, Room 7C-034, Forrestal Building Washington, DC 20585 (202) $586-4640$

Advises DOE's senior management on issues related to the Department's national security, energy emergency, asset management/privatization initiatives and environmental restoration management policies.

Formulates and recommends policies, plans and guidance for DOE's defense environmental restoration, safety and health, asset management and privatization and energy emergency activities. Analyzes the economic, financial, technical, trade and institutional factors that affect the Department's national security, energy emergency, environmental restoration/waste management and safety and health activities. Works closely with other Department and Government offices, and domestic and international institutions to coordinate and harmonize national security, energy emergency, waste management, asset management and privatization, environmental restoration, safety and health policies.

182 Office of National Security Analysis

Jon K. Schafer, Director

PO-51, Room 8F-089, Forrestal Building

Washington, DC 20585

(202) $586-1278$

Conducts studies and analyses; formulates and recommends policies, plans, and guidance; and advises DOE's senior management on issues regarding Departmental national security functions.

183 Office of Materials-Asset Management

Analysis

Jack Blanchard, Director

PO-52, Room 8F-055, Forrestal Building

Washington, DC 20585

(202) $586-6703$

Conducts studies and analyses and provides advice and counsel on Department policies and procedures associated with materials and asset management programs, privatization initiatives and environmental restoration management policies. 
184 Office of the Deputy Assistant Secretary for Energy, Environmental and Economic Policy Analysis

Abraham E. Haspel, Deputy Assistant

Secretary

PO-6, Room 7C-034, Forrestal Building

Washington, DC 20585

(202) 586-5316

Responsible for issues related to energy supply and demand, and their impact on the environment and on the economy of the U.S. and other nations.

Manages policy development processes in the areas of electricity, natural gas, oil, alternative fuels and energy efficiency and ensures their integration into broad department policy analysis and implementation. Provides analysis of environmental policy and environmental security issues affecting the general economy and the energy sector, specifically those which serve as the basis for interagency consultations and formal regulatory interventions. Serves as coordinator and policy lead in the area of Global Change Policy. Synthesizes the various policy positions, ensures the effective integration of policy development activities, and supports the development of plans and positions on the energy-related aspects of domestic and international environmental and economic issues.

\section{5}

\author{
Office of Economic, Electricity \\ and Natural Gas Analysis \\ Howard K. Gruenspecht, Director \\ PO-61, Room 7H-034, Forrestal Building \\ Washington, DC 20585 \\ (202) $586-4767$
}

Responsible for providing: (1) economic analysis of energy-related policies and initiatives; (2) support related to the assessment, development, and use of economic models and analytic capabilities required for integrated national energy policy analysis; (3) responses to the requirements of Congressional mandates; analysis of future energy impacts, integrated international energy demand, supply, and price analysis, domestic energy supply and demand analysis and environmental impacts; (4) economic, mathematical/statistical, and energy expertise to other offices in PO. Acts as a clearinghouse for all economic modeling issues and analyses, ensuring the quality and completeness of the analyses.

In the area of electricity analysis, provides analyses of and recommendations on policy issues associated with the economic, technical, environmental, regulatory, and institutional factors that affect the supply and demand of electric energy; expertise related to electric power generation from all fuels and technology; electric power transmission; and integrated resource planning; and the lead for the development of national policy on Federal and state regulation of electric power.

In the area of natural gas analysis, provides analyses and recommendations on policy issues associated with domestic and international gas markets; economic analyses of the natural gas industry, incentives designed to stimulate increased gas production or greater gas conservation, and government policies regarding regulation of domestic natural gas markets; and broad-based technical support in areas of gas industry structure, production and supply modeling, and economic analysis to other DOE Offices.

Provides analysis and develops options with respect to significant domestic and global environmental issues with the potential to affect the U.S. energy systems, particularly with respect to the demand, supply, and price of electricity and natural gas within the United States.

186 Office of Energy Efficiency, Alternative Fuels and Oil Analysis Carmen Difiglio, Director PO-62, Room 7H-021, Forrestal Building Washington, DC 20585 (202) 586-4444

Responsible for the development, analysis and review of policies and issues in the following areas: energy efficiency, alternative fuels, oil supply and refining, environmental security, global environmental impacts affected by energy efficiency, alternative fuels, or oil production, refining and use, and criteria emissions affected by energy efficiency, alternative fuels, or oil production, refining and use, in order to further energy efficiency and use of alterative transportation fuels; reduce domestic reliance on imported petroleum; maintain reliable supplies of reasonably priced oil-based fuels; reduce climate altering and criteria emissions; and encourage sustainable development.

187 Office of the Deputy Assistant Secretary for International Energy Policy, Trade and Investment

David J. Jhirad, Deputy Assistant Secretary PO-7, Room 7C-034, Forrestal Building Washington, DC 20585 (202) $586-5493$

Directs and coordinates Departmental relations with other nations and with specialized international organizations. Responsible for developing and conducting international energy policy consistent with U.S. foreign policy objectives. Directs and coordinates the Department's trade, investment and export promotion programs including coordination within the Department, with other U.S. Government 
agencies through the Trade Promotion Coordinating Committee (TPCC), and with the U.S. private sector. Sets strategic objectives and priorities for worldwide export promotion activities and provides leadership on energy and environmental export issues in the TPCC. Responsible for monitoring and analyzing world energy market developments and the international political, economic, and strategic factors that influence these developments; providing policy recommendations on a wide range of international energy security issues; managing U.S./DOE bilateral relationships and participation in international energy organizations; ensuring protection of U.S. interests in bilateral and multilateral treaties and obligations that affect energy services, commodities, and technology.

\section{8}

\author{
Office of Policy Analysis, Trade and \\ Investment for Europe, Newly Independent \\ States (NIS) and the Middle East \\ Leonard L. Coburn, Director \\ PO-71, Room 7G-090, Forrestal Building \\ Washington, DC 20585 \\ (202) 586-6383
}

Responsible for developing strategies to foster energy investment and trade. Formulates policies designed to remove impediments to international energy trade and improve accessibility in world energy markets. Analyzes energy policy, market trends, investment and trade issues and their impact on U.S. national security, foreign policy and trade policy objectives. Coordinates DOE policy issues and maintains working relationships with specific nations and international organizations. Implements policies and programs aimed at enhancing exports of U.S. energy services, commodities and equipment and serves as the Department's focal point for energy firms seeking Federal assistance to overcome barriers in overseas markets. Responsible for solving practical international energy emergency problems and for promoting new responses for dealing with the problems through multilateral and bilateral activities.

189 Office of Policy Analysis, Trade and Investment for the Americas, Asia Pacific and Africa

David Pumphrey, Director

PO-72, Room 7G-076, Forrestal Building

Washington, DC 20585

(202) $586-6832$

Responsible for developing strategies to foster energy investment and trade that will improve energy security, strengthen economic competitiveness and further global environmental initiatives. Formulates policies designed to remove impediments to international energy trade that will improve accessibility in world energy markets. Analyzes energy policy, market trends, investment and trade issues and their impact on U.S. national security, foreign policy and trade policy objectives. Coordinates DOE policy issues and maintains working relationships with specific nations and international organizations. Implements policies and programs aimed at enhancing exports of U.S. energy services, commodities and equipment and serves as the Department's focal point of energy firms seeking Federal assistance to overcome barriers in overseas markets.

190 Office of the Deputy Assistant Secretary for Science and Technology Policy and Cooperation Jessie Harris, Deputy Assistant Secretary PO-8, Room 7C-034, Forrestal Building Washington, DC 20585 (202) $586-7180$

Develops science and technology policies with regard to Departmental missions, specifically: fundamental science, mission-driven research and development, laboratory mission and management, and international cooperation on science and technology issues. Conducts studies and projects that serve the strategic corporate interests of the Department. This work includes analysis and recommendations on Departmental research and development investment priorities, management structure and communications strategies. Works closely with the Department's business lines to guide and coordinate their individual research, development, deployment and international collaboration strategies. Serves as the Department's science and technology policy liaison with external organizations, coordinating and harmonizing science and technology policy.

\section{Office of Science and Technology Policy} Analysis

Robert C. Marlay, Director

PO-81, Room 7H-085, Forrestal Building

Washington, DC 20585

(202) $586-3900$

Coordinates and recommends domestic science and technology policies relating to the Department's energy, science, environmental and national security missions, management structure, and communications strategies. Analyzes the Department's overall science and strategic research investment portfolio with respect to priorities and alignment with Departmental and national goals, and provides related budgetary and program guidance. Works closely with the various Departmental elements to develop and advance Departmental and national science and technology goals, strategies, and initiatives. Serves as the Department's technology policy liaison with outside organizations, including the White House Office of Science and Technology Policy, and other agencies and institutions. 
Office of International Science and

Technology Cooperation

Robert S. Price, Director

PO-82, Room 1E-218, Forrestal Building

Washington, DC 20585

(202) $586-6770$

Oversees the development and negotiation of DOE international science and technology cooperation agreements. Works closely with all Departmental Program Offices, the State Department, Office of Science and Technology Policy and other agencies to assure consistency of international science and technology activities with domestic technology policy, with the Department's energy, economic, environmental, and national security mission, and with U.S. foreign policy objectives.

\section{3}

\author{
Office of Civilian Radioactive Waste \\ Management (RW) \\ Daniel A. Dreyfus, Director \\ RW-1, Room 5A-085, Forrestal Building \\ Washington, DC 20585 \\ (202) 586-6842 \\ Fax: (202) 586-6636
}

Public Information System

(800) 225-6972

Responsible for the implementation of the Nuclear Waste Policy Act (NWPA) P. L. 97-425, as amended. Provides for the development of repositories for the disposal of high-level radioactive waste and spent nuclear fuel, including development of interim storage capabilities prior to the availability of a repository for permanent disposal, in a manner that fully protects the public health and safety.

\section{Office of Quality Assurance \\ Donald G. Horton, Director \\ RW-3, Room GF-253, Forrestal Building \\ Washington, DC 20585 \\ (702) 794-7675}

Responsible for the development, management, coordination, integration, and overview of RW quality assurance activities. The Nuclear Regulatory Commission (NRC) has prescribed quality assurance requirements for all aspects of the civilian radioactive waste management program related to waste isolation and worker safety. It is DOE's responsibility as the license applicant, to ensure that the appropriate management, policy, training, inspection and audit controls are in place for verification by the NRC that the structures, systems, and components under postulated accident conditions will not adversely impact the waste isolation capabilities of the site, and not cause undue risk to the health and safety of the workers associated with the operation of the facility or the public at large. In addition, the
Office is responsible for conducting internal audits at both Headquarters and site locations and of contractors associated with the program; performing quality surveillance of Federal and contractor records; identifying deficiencies and preparing corrective action reports; providing administrative management of the Quality Concerns Management System reporting; evaluation/investigation, and resolution system; providing coordination and oversight of programwide self-assessment activities and providing regulatory compliance oversight in the implementation of safety and health performance strategies.

\section{Office of Human Resources and}

Administration

James Bresee, Acting Director

RW-10, Room GF-253, Forrestal Building

Washington, DC 20585

(202) 586-9173

Develops the Total Quality Management (TOM) program for RW, manages the procurement/business activities of the Management and Operating (M\&O) contract and all other RW contracts; oversees and administers the award fee process for the $M \& O$ contractor; monitors performance of the contractor; analyzes $M \& O$ cost and schedule information; serves as liaison with RW entities and the DOE Procurement Office; develops and implements a national education program; prepares RW's Annual Report to Congress; manages public relations activities; and develops and implements the Customer Advocacy Plan and serves as the point of contact to DOE's ombudsman; performs information resources management activities; manages resources necessary to support DOE's information systems, software, and contractor support resources; provides correspondence management and mail distribution.

196 Yucca Mountain Site Characterization Office Wesley E. Barnes, Project Manager

P.O. Box 98608

Las Vegas, NV 89193

(702) 794-1300

Responsible for scientific evaluations needed to determine whether the Yucca Mountain candidate site is suitable for a geologic repository and for waste-package and repository design and development in compliance with the Nuclear Waste Policy Act (NWPA), as amended; developing and conducting surface-based and underground site characterization; developing the physical subsystem (e.g., natural and engineered barriers) required to dispose of the high-level waste; providing the technical lead for interactions with the Nuclear Waste Technical Review Board (NWTRB); developing, maintaining, and implementing policy and management plans that will ensure all programmatic 
and physical subsystem interfaces are identified, established, documented, and controlled; preparing cost, schedule, and technical baseline for the disposal subsystem; developing, operating, and evaluating the technical data base; providing analyses of NRC or other regulatory reports and developing strategies to support rulemaking or closure of issues with the NRC; developing and implementing a waste package implementation strategy; developing and implementing an environmental program; developing, implementing, and evaluating safety and health strategies and results; designing and implementing a Licensing Support System; and managing socioeconomic, impact mitigation, transportation, and financial assistance activities associated with geological disposal.

\section{Office of Program Management and Integration}

Ronald A. Milner, Director

RW-30, Room 7F-031, Forrestal Building

Washington, DC 20585

(202) $586-9694$

Responsible for integrating the development and implementation of RW's strategic planning program; developing a comprehensive contingency planning program; coordinating interactions with the NRC, NWTRB and the National Academy of Sciences; developing and managing an international program; integrating policy and strategy for risk management, communication, and perception issues in consultation with the Yucca Mountain Office and the Office of Waste Acceptance, Storage and Transportation (OWAST), developing and issuing the Program Management System Manual and maintaining the Program Document Hierarchy; developing program control and project management system policy, requirements, and guidance, integrating input to, and developing and maintaining the Program Cost and Schedule Baseline document; integrating development of the annual program work plans; performing Total System Life Cycle Cost analyses and preparing periodic reports; developing and maintaining the Project Decision Schedule; developing, coordinating, and maintaining the overall RW program work breakdown structure; preparing and executing RW budgets; analyzing and evaluating program progress and performance; managing the annual Nucear Waste Fund (NWF) fee adequacy analysis; administration of the NWF, Defense Nuclear Waste Disposal appropriations, and the Civilian Radioactive Waste Research and Development fund; establishing policy and coordinating and implementing systems engineering activities at the program level; identifying functional/program system engineering interfaces to be assigned to YMSCO and OWAST, including the establishment and maintenance of a system for conflict resolution; conducting systems engineering analyses to ensure system level changes are acceptable from a programwide viewpoint; establishing program-level regulatory policy and requirements; coordinating and integrating safety and health performance strategies for the repository and waste acceptance, storage, and transportation programs; providing regulatory support and policy guidance for alternative licensing strategies; and serving as the overall NEPA Compliance Officer in coordinating input from System Elements/Projects and consolidating monthly reports for the Office of Environmental, Safety and Health.

198 Office of Waste Acceptance, Storage and Transportation

Samuel Rousso, Director

RW-40, Room 7F-059, Forrestal Building

Washington, DC 20585

(202) $586-9116$

Responsible for managing the design, certification, and production of multipurpose canisters; developing, implementing, and managing the siting program; preparing the license application of the NRC for an RW-operated storage facility; developing implementation policies needed to produce the waste storage subsystem in compliance with requirements documents and applicable laws and regulations; developing policy and implementing procedures for site selection; developing, evaluating, and documenting site criteria; developing the physical subsystem required to store high-level waste; developing NEPA compliance strategies through the Environmental Impact Statement (EIA) scoping process and developing EIA implementation plans; preparing cost, schedule, and technical baseline for the storage and transportation subsystems; and managing spent fuel storage research and development activities. Manages the utility contracts and serves as the primary technical interface with nuclear utilities; performs fee verification analyses for both one-time and ongoing Nuclear Waste Fund fees; prepares the Annual Capacity Report and the Acceptance Priority Ranking Report; and develops and conducts the implementation of safeguards and security activities. Develops and operates a comprehensive system to transport spent nuclear fuel and high-level radioactive waste to appropriate Federal waste management facilities, including cask system development and equipment acquisition; economic and systems analyses appropriate for transportation system development; and support system and operational planning implementation. 
Federal Energy Regulatory Commission (FERC)

199 Office of External Affairs

Rebecca Schaffer, Director

EA-1, 888 First Street, N.E.

Suite $11 \mathrm{H}$

Washington, DC 20426

(202) 208-0004

Responsible for the public relations of the Commission. This responsibility is executed by providing informational and educational services to the Congress; international, Federal, state and local governments; the general public; consumer and public interest groups; trade associations; regulated industries; and the news media.

\section{0}

\author{
Division of Press Services \\ Hedley Burrell, Director \\ EA-10, 888 First Street, N.E. \\ Suite $11 \mathrm{H}$ \\ Washington, DC 20426 \\ (202) 208-1088
}

Meets the informational needs of the news media on the full range of energy regulatory subjects and proceedings within the Commission's jurisdiction. Develops news releases and informational materials. Responds to media inquiries about Commission programs and activities. There are information specialists in the fields of natural gas, electricity and hydroelectric projects in this Division.

201 Division of Congressional, Intergovernmental and Public Affairs

Don Chamblee, Director

Carol Connors, Deputy Director

EA-20, 888 First Street, N.E.

Suite $11 \mathrm{H}$

Washington, DC 20426

(202) 208-0870

Serves as liaison with Congress, Federal agencies and the public. Coordinates presentation of Commission hearings, briefings, and reviews information pertaining to legislative issues and proposals. Responds to inquiries from public, industry, interest groups, and Federal, State and local governments about Commission activities, actions, and procedures. Develops informational and educational materials on energy regulatory subjects and processes and responds to Freedom of Information and Privacy Act inquiries or other written, oral and telephone requests for information. Serves as a communications link with the National Association of Regulatory Utility Commissioners and their member state commissions.
Department of Energy Laboratories, Field Facilities, and Power Administrations

Following are alphabetical listings of DOE Operations Offices, as well as DOE facilities that are not under direct supervision by a university or DOE Operations Office. The list does not include the various area offices of DOE or its affiliated installations.

\section{DOE Laboratories and Field Facilities}

202 Albuquerque Operations Office

U.S. Department of Energy

Office of Public Affairs

David L. Geary, Director

P.O. Box 5400

Albuquerque, NM 87185-5400

(505) 845-6202

Fax: (505) 845-5438

The mission of the Office is to contribute to the welfare of the nation by providing field-level Federal management to assure effective, efficient, safe and secure accomplishment of the Department of Energy's national defense, environmental quality, science and technology, technology transfer and commercialization, and national energy objectives. Oversees a system for safe and secure transport of all government-owned special material of strategic quantities.

\section{Ames Laboratory}

Steve Karsjen, Manager

Office of Public Affairs and Information

111 T.A.S.F.

lowa State University

Ames, IA 50011-3020

(515) 294-1856

Fax: (515) 294-3226

Established in 1947 as a result of the Manhattan Project. The primary mission is to conduct basic research in materials and chemical sciences, chemistry, physics, engineering, metallurgy, mathematics, and related research in materials reliability and nondestructive evaluation.

\section{Argonne National Laboratory}

Charles A. Osolin, Director

Office of Public Affairs

9700 South Cass Avenue

Argonne, IL 60439-4803

(708) 252-5581

Established in 1947. Conducts applied research and engineering development in nuclear fission and other energy technologies and scientific research in basic physical and life sciences. Develops and operates research facilities for members of the scientific community, maintains close interaction with 
personnel in universities and industry, and aids in the education of scientists and engineers.

\section{Bartiesville Project Office}

U.S. Department of Energy

Herbert A. Tiedemann

Technology Transfer

P.O. Box 1398

Bartlesville, OK 74005

(918) $337-4293$

Fax: $(918) 337-4418$

Administers and monitors the DOE Fossil Energy Oil Research program, with emphasis on research related to petroleum extraction, processing, and utilization.

\section{Battelle Pacific Northwest National \\ Laboratory \\ Gary Petersen, Director \\ Communications \\ P.O. Box 999 \\ Richland, WA 99352 \\ (509) 375-2924 \\ Fax: (509) 375-2221}

Battelle Memorial Institute operates the Pacific Northwest National Laboratory (PNNL). PNNL's mission is two-fold. As one of the Government's multi-program national laboratories, it performs basic and applied research for DOE, other Government agencies, and industry. As the technical center for Hanford, the Laboratory provides research expertise and program support for DOE and its contractors. More than 1,500 research projects are conducted annually in support of DOE missions in energy development, national defense, and international competitiveness. PNNL actively pursues transfer of Federally funded technologies to industry and academic support through educational enrichment programs and collective research with universities. Headquartered in a private research complex in north Richland, Battelle operates extensive PNNL facilities on the Hanford Site. Battelle also conducts a variety of aquatic studies at a mainline research laboratory at Sequim Bay on the Olympic Peninsula and operates the Battelle Seattle Research Center.

\section{Brookhaven National Laboratory}

Anne Baittinger, Public Affairs Manager Upton, NY 11973

(516) 344-2123

Established in 1947, conducts basic and applied research in technology base areas, supports research facilities, and establishes new directions for research. Major disciplinary strengths are high energy, nuclear and solid state physics, chemistry, environmental and life sciences, and selected energy technologies.

\section{Chicago Operations Office}

Gary L. Pitchford, Director

Office of Communications

9800 South Cass Avenue

Argonne, IL 60439

(630) 252-2013

Fax: (630) 252-2527

An offspring of the Manhattan Engineer District and established as one of the Atomic Energy Commission's first field offices in 1947, the Office is responsible for integrated management of major Government-owned, contractor-operated laboratories and facilities (Argonne National Laboratory, Brookhaven National Laboratory, Fermi National Accelerator Laboratory, Princeton Plasma Physics Laboratory, and Ames Laboratoryl, as well as two Government-owned and operated laboratories (Environmental Measurements Laboratory and New Brunswick Laboratory). Program and project assignments include high energy physics, environmental restoration and waste management, nuclear physics, basic energy sciences, advanced reactor safety, magnetic fusion energy, solar and alternate energy, and an assortment of research and development initiatives in various energy technologies.

209 Environmental Measurements Laboratory (EML)

U.S. Department of Energy

201 Varick Street, 5th Floor

New York, NY 10014-4811

(212) 620-3619

Fax: (212) 620-3600

Founded in 1947, EML is a government-owned, government-operated laboratory that addresses important scientific issues concerning energy related pollutants in the environment with emphasis on characterization, restoration, decommissioning, waste management and their attendant quality assurance needs. EML conducts research on radioactive and other energy-related pollutants through which it provides the Office of Environmental Management, other DOE offices and other Federal agencies with the in-house capability to respond effectively and efficiently to estimates of risk of human exposure to these pollutants and to environmental and national security issues.

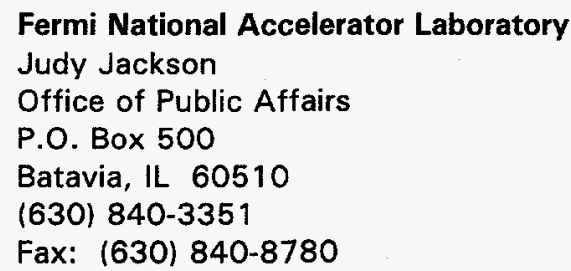

Established in 1967 to explore the field of elementary particle physics so that the understanding 
of the basic structure of matter may be broadened. The lab's principal scientific tool is the Tevatron--the world's first superconducting accelerator and currently the highest energy accelerator in the world. Protons and antiprotons travel at nearly the speed of light in the Tevatron's tunnel, which is 6.3 kilometers in circumference.

\section{Grand Junction Projects Office George Rael, Acting Manager 2597 B-3/4 Road \\ Grand Junction, CO 81503 \\ (970) 248-6000 \\ Fax: (970) 248-6023}

The primary mission is to apply its project management, engineering, and geoscience capabilities to support national programs in environmental restoration, geoscience, and energy. Activities include: the Grand Junction Uranium Mill Tailings Remedial Action (UMTRA) vicinity properties project; the Monticello, Utah, mill site and vicinity properties project; the CERCLA Superfund uranium mill tailings remedial action project; the remediation of DOE's Grand Junction Projects Office; and the DOE-wide Long-Term Surveillance and Maintenance Program. This Office, which became involved with environmental restoration in 1973 with the Grand Junction Remedial Action Program (GJRAP), is also involved with environmental restoration of other DOE sites as requested.

\section{Hanford Environmental Health Foundation Laura Angyus \\ Communications \\ P.O. Box $100 \mathrm{H} 1-52$ \\ Richland, WA 99352 \\ (509) 376-4101 \\ Fax: (509) 372-3139}

Provides occupational health services through health risk management and occupational health products and services to personnel at the Hanford Site, under contract with the U.S. Department of Energy.

\section{Idaho Operations Office}

U.S. Department of Energy

Ronald A. King, Director

Office of Communications

850 Energy Drive

Idaho Falls, ID 83401

(208) 526-7300

Established in 1949. Supports the engineering and operations efforts of the Department of Energy and other Federal agencies in nuclear safety research, reactor development, reactor operations and training, defense-related materials production, waste management and technology development, and energy technology and conservation programs. Promotes industry collaboration in science, technology, and research to enhance U.S. industrial competitiveness. Administers the Idaho National Engineering Laboratory.

\section{Kaiser Engineers Hanford Company}

K. B. Adamson, Manager, Administration P.O. Box 888

Richland, WA 99352

(509) 376-6967

Performs the architectural-engineering construction for the Department of Energy Hanford Site.

\section{Lawrence Berkeley National Laboratory (LBNL) \\ University of California \\ Ron Kolb, Head, Public Communications \\ 1 Cyclotron Road \\ Building 50A/4112 \\ Berkeley, CA 94720 \\ (415) 486-5771 \\ URL: http://www.lbl.gov/}

Founded in 1931 to advance the development of the cyclotron invented by Ernest Lawrence. Currently, the major roles of LBNL are to perform multidisciplinary research in the general, energy, and life sciences; develop and operate unique national experimental facilities; educate and train the next generation of scientists and engineers; and foster productive relationships between LBNL and industry. Research programs include high energy physics, materials science and chemistry, medical and biological science, energy conservation and storage, environmental science, medical and biological science, earth science, chemical biodynamics, instrumentation, and advanced accelerator design. The world's most advanced electron microscopes and medium energy particle accelerator are operatec' at LBNL and are availabie for use by industrial and other researchers. In 1993, a unique source of synchrotron radiation, the Advanced Light Source, came online to serve a variety of researchers.

The newest addition to Berkeley Lab's user inventory, the National Energy Research Scientific Computing Center (NERSC), places the Laboratory center-stage in the global computer technology revolution. NERSC provides high-performance computing and networking services to the nation's energy research community. It includes an array of supercomputers, an adjunct network that runs at speeds of up to 155 million bits per second, and a team of experts that will help define the future of supercomputing. 


\section{6}

\author{
(LLNL) \\ University of California \\ J. C. Richardson, Director of \\ Communications \\ P.O. Box 808 , L-404 \\ Livermore, California 94550 \\ (510) 422-4599 \\ Fax: $(510)$ 423-2943
}

Lawrence Livermore National Laboratory

Managed by the University of California for the U.S. Department of Energy, conducts research important to national goals, including national defense. Current research programs include weapons, energy, biomedicine and the environment. The Laboratory also has a longstanding commitment to protect the environment and enhance the Nation's economic competitiveness.

\section{Los Alamos National Laboratory (LANL) \\ University of California \\ William Heimbach, Public Information Officer \\ Mail Stop $\mathrm{C} 177$ \\ Los Alamos, NM 87545 \\ (505) 667-7000}

Established in 1943 to develop the world's first nuclear weapons, the primary mission is the application of science and technology to significant problems that impact national security in its broadest sense, including reducing the global nuclear danger, and maintaining a strong defense, economic competitiveness, educational excellence, environmental restoration, and energy independence.

\section{Morgantown Energy Technology Center (METC) \\ Office of Public Affairs \\ Rodney J. Anderson \\ P.O. Box 880 \\ Morgantown, WV 26507-0880 \\ (304) 285-4709 \\ Fax: (304) $285-4403$}

METC's Mission is to enhance the United States' economic competitiveness, environmental quality, and national well-being through the development and deployment of the world's cleanest, lowest cost, most reliable, and most efficient technology products for the energy sector. Provides technology and management expertise to solve energy and related environmental problems of national scope. Provides a broad range of technical management services to implement national RD\&D programs in advance energy and environmental technologies. These programs span four business sectors--Advanced Power Systems using fossil fuel coal and natural gas, Fuel Resources, Environmental and Waste Management, and technical management services for other agencies of the Federal government. Within these business sectors, METC develops technology options for our customers so that their customers are better served.

METC performs 80 percent of its business through procured RD\&D. The industrial partners share over 50 percent of the total cost of all METC's procured RD\&D. The result is an industry contribution of over $\$ 2.8$ billion in active contracts. This co-funding reduces risk and accelerates market entry of the most cost-effective and promising technologies. METC also maintains a strong technology base with on-site researchers and off-site partners. METC's technology base activities develop novel concepts based on scientific and engineering principles, determine solutions to product development problems, and further the transfer of new technology concepts to support METC's product development.

\section{National Renewable Energy Laboratory (NREL) \\ Marguerite Kelly, Center Director \\ Communications \\ 1617 Cole Boulevard \\ Golden, CO 80401 \\ (303) 275-4099}

Fax: (303) 275-3619

Formerly known as the Solar Energy Research Institute (SERI), NREL focuses on energy efficiency and renewable energy technology development in the four major energy use sectors--buildings, industry, transportation, and utilities--in support of DOE's Assistant Secretary for Energy Efficiency and Renewable Energy. As the principal laboratory for basic and applied research and development in the solar energy conversion technologies, NREL conducts exploratory studies, experimentation and testing in its own facilities, and supports contract research and development with industries and universities throughout the country.

220 Naval Petroleum and Oil Shale Reserves in Colorado, Utah, and Wyoming, NOSR-1, NOSR-2, NOSR-3

U.S. Department of Energy

Clarke Turner, Director

907 N. Poplar Street, Suite 150

Casper, WY 82601

(307) 261-5161

Fax: (307) 261-5817

Founded between 1912 and 1924 and created to provide an emergency source of liquid fuels for the U.S. Armed Forces. Congress mandated production of the Naval Petroleum Reserves at the Maximum Efficient Rate with the Naval Petroleum Reserves Production Act of 1976 to sell liquid fuels and gas to the private sector providing profits to the U.S. Treasury. 
221 Naval Petroleum Reserves in California

U.S. Department of Energy

O. Jay Williams

P.O. Box 11

Tupman, CA 93276

(805) 763-6011

Fax: (805) 763-6699

Founded between 1912 and 1924 and made a permanent reservation for future naval fuel and oil supplies. Congress mandated the Reserves through the Naval Petroleum Reserves Productions Act.

\section{Nevada Operations Office}

U.S. Department of Energy

Office of Public Affairs Information

Darwin J. Morgan, Director

P.O. Box 98518

Las Vegas, NV 89193-8518

(702) 295-3521

Manages operations and programs at the 1,350 square-mile Nevada Test Site which is a vast outdoor laboratory, where the following core competencies are maintained:

National security support through safety and reliability experiments to sustain a Presidential mandated state of readiness to resume nuclear testing.

- Crisis management by managing threats and emergency hazardous situations including radiological emergency response programs based at Nellis Air Force Base, Nevada, and Andrews Air Force Base, Maryland.

Exploring alternative energy sources to meet future energy demands.

Environmental management commitments including cleanup technologies, managing an approved major defense low-level radioactive waste disposal site, remote sensing, and monitoring.

- Special nuclear material management in support of safe dismantlement of nuclear weapons and weapons materials management.

Science and technology partnerships with Federal, state and local governments, universities, and national laboratories to promote science and technology in support of the Nevada Test Site as a National Environmental Research Park, related educational programs, and commercial opportunities.
Administrative support programs for the U.S. Department of Energy's Yucca Mountain Project.

\author{
Oakland Operations Office \\ U.S. Department of Energy \\ John Belluardo, Director \\ Office of Public Affairs \\ 1301 Clay Street, Room 700N \\ Oakland, CA 94612-5208 \\ (510) 637-1809 \\ Fax: (510) $637-2015$
}

Serves the public by executing programs, performing contract management, and conducting operational oversight of National Laboratories, research and development contractors and grantees in support of the Department of Energy requirements and priorities.

\section{Oak Ridge National Laboratory}

Joe W. Culver, Director

Communications and Public Affairs

Lockheed Martin Energy Research Corp.

P.O. Box 2008

Oak Ridge, TN 37831-6266

(423) $574-4160$

Fax: (423) 576-0235

Performs research supported by DOE on a broad range of energy-related problems and provides technical information and assistance on energy research for State and local governments and the private sector. Areas of research include waste management, fossil, nuclear, fusion, conservation, and environment. Reports on technology applications are available.

\section{Oak Ridge Operations Office (ORNL)}

U.S. Department of Energy

Steven L. Wyatt, Director of Public Affairs

P.O. Box 2001

Oak Ridge, TN 37830-8502

(423) 576-0885

Fax: (423) 576-1665

Administers the Oak Ridge National Laboratory; the Oak Ridge Associated Universities; the Oak Ridge, Portsmouth, and the Paducah Gaseous Diffusion Plants; the Y-12 Production Facility; the Thomas Jefferson National Accelerator Facility; and Weldon Spring Site Remedial Action Project. Major programs and projects include $(1)$ direction of $R \& D$ programs related to nuclear and other energy sources, (2) landlord management of uranium enrichment facilities, (3) direction of biomedical and environmental research, (4) dismantlement and storage of nuclear weapons components, (5) 
oversight of DOE's Formerly Utilized Sites Remedial Action Project, and (6) DOE metals asset management program.

\section{Pittsburgh Energy Technology Center (PETC) U.S. Department of Energy \\ Sun W. Chun, Director \\ Kay Downey, Technology Transfer Officer P.O. Box 10940 \\ Pittsburgh, PA 15236-0940 \\ (412) 892-4687}

The Pittsburgh Energy Technology Center (PETC) is one of the U.S. Department of Energy's principal fossil energy field offices leading the development and demonstration of a new generation of technologies that are designed to use coal, oil, and gas in a more efficient and environmentally acceptable manner. PETC is responsible for technical and administrative management of several hundred research and development contracts, grants, and cooperative agreements with industry, academia, and other research organizations. Lead program areas include Clean Fuels Technologies, Advanced Electric Power Technologies, and Advanced Research. PETC's activities also include managing 27 projects under the Government's multi-year, multi-billion dollar Clean Coal Technology Program. In addition, PETC conducts exploratory and applied in-house research and development in support of national fossil energy technology programs that are managed by PETC. The Center implements a number of international cooperative agreements with Canada, England, India, Italy, Japan, Mongolia, Ukraine, Poland, the People's Republic of China, and the Republic of Korea, and sponsors international conferences and exchanges on a broad spectrum of energy and environmental issues. the PETC staff has strong scientific and technical capabilities and is equally strong in program development and project management. PETC has a full range of technical, administrative, and legal capabilities for negotiating and managing the complex multi-party agreements that are central to effective technology advancement.

\section{Pittsburgh Naval Reactors Office}

U.S. Department of Energy

Henry A. Cardinal, Manager

814 Pittsburgh McKeesport Boulevard

West Mifflin, PA 15122-0109

(412) 476-7200

Oversees the Bettis Atomic Power Laboratory in West Mifflin, Pennsylvania, and the Naval Reactors Facility near Idaho Falls, Idaho. The Bettis Atomic Power Laboratory and the Naval Reactors Facility perform research and development of naval nuclear propulsion plants and operate associated prototype plants.

\section{Portsmouth Site Office}

U.S. Department of Energy

Gene Gillespie, Manager

P.O. Box 700

Piketon, $\mathrm{OH} 45661$

(614) $897-5010$

Responsible for the technical administration of the contract for the management, operation, and maintenance of the Department of Energy's uranium enrichment production plant at Portsmouth, Ohio. Responsibilities include monitoring day-to-day production operations to assure that contractor-executed functions are carried out in a manner that achieves a quality product and that operations are conducted in a manner that protects personnel, the general public, and the environment.

229 Princeton Plasma Physics Laboratory (PPPL)

Anthony R. DeMeo, Jr., Head

Information Services

P.O. Box 451

Princeton, NJ 08543

(609) 243-2755

E-Mail: ademeo@pppl.gov

URL: http://www.pppl.gov

The Princeton Plasma Physics Laboratory is a world leader in the development of magnetic fusion energy as a safe, inexhaustible and environmentally attractive means of generating electricity for the long term. Presently PPPL operates one of the world's largest, most advanced magnetic fusion devices--the Tokamak Fusion Test Reactor, as well as a smaller machine, the Current Drive Experiment-Upgrade. PPPL researchers are leading the design of an advanced concept fusion device--the National Spherical Tokamak Experiment. In addition, PPPL physicists are participating in a worldwide collaboration to design the International Thermonuclear Experimental Reactor. PPPL staff are applying knowledge gained in magnetic fusion research to a number of other theoretical and experimental areas including materials science, chemistry, solar physics and manufacturing.

230
Richland Operations Office
U.S. Department of Energy
Karen Randolph, Director
Office of External Affairs
P.O. Box 550, MS A7-75
Richland, WA 99352
(509) 376-7501

Manages the Hanford Site. The 1,450 Square kilometers ( 560 square miles) Hanford Site, located near Richland in southeastern Washington state was founded in the early 40's to produce plutonium for the nation's defense program. The production mission has ended and the present mission is 
committed to clean up the site, provide scientific and technological excellence to meet global needs, and partner in the economic diversification of the region. Nuclear and hazardous waste management, interim storage and ultimate disposal of high level nuclear waste, and environmental management are the primary programs at Hanford. Also at Hanford is the Department's Pacific Northwest National Laboratory. The Laboratory's mission is to conduct research and development to meet national needs in energy, environment, the economy and national security.

\section{1}

\author{
Sandia National Laboratories \\ Rod Geer \\ Employee Communications and Media \\ Relations \\ Department 12640 \\ P.O. Box 5800 \\ Albuquerque, NM 87185 \\ (505) 844-6601 \\ Fax: (505) 844-6367
}

Established in 1949 to assist in developing a national nuclear deterrent, Sandia has major laboratories in New Mexico and California (Livermore). With more than 8,000 employees, Sandia operates facilities for manufacturing process development, environmental testing, radiation research, combustion research, computing, and microelectronics research and production. Over Sandia's history, its missions have expanded from an original focus on nuclear weapons $R \& D$ to work on other advanced military technologies, energy programs, arms verification and control technology, and applied research in numerous scientific fields, including an extensive program in materials research. In addition to developing and engineering nuclear weapon components, Sandia assesses, maintains, and upgrades the existing nuclear weapon stockpile and explores advanced weapon concepts. Sandia has the largest arms-control verification technology program in the country. It is the DOE center for pulsed-power research. Sandia also is working to strengthen the nation's economic security by transferring the commercially valuable technologies developed at the labs to U.S. industry.

\section{Savannah River Operations Office U.S. Department of Energy \\ Office of External Affairs \\ P.O. Box A \\ Aiken, SC 29802 \\ (803) 725-2889 \\ Fax: (803) 725-4657}

The Savannah River Operations Office provides leadership, direction, and oversight to ensure that programs, operations, and resources are managed in an open, safe, environmentally sound, and costeffective manner to: o

0
Restore the environment and manage natural resources.

Develop mission-supportive technology partnerships.

Manage the disposition of nuclear materials and facilities.

Support current and future national security and nuclear materials requirements.

Store, treat, stabilize and dispose of waste materials.

Schenectady Naval Reactors Office (SNR)

U.S. Department of Energy

A. P. Muir, Public Information Officer

P.O. Box 1069

Schenectady, NY 12301

(518) 395-6383

Negotiates and administers contracts for the operation of the Knolls Atomic Power Laboratory and for the procurement of fuel required for the Naval Nuclear Propulsion Program. Administers all technical and non-technical aspects of these contracts.

\section{Stanford Linear Accelerator Center Stanford University \\ P. A. Moore, Assistant to the Director \\ P.O. Box 4349, MS-80 \\ Stanford, CA 94309 \\ (415) $926-2613$}

Built and operated by Stanford University, the Stanford Linear Accelerator Center is a national laboratory dedicated to research in elementary particle physics and to the uses of synchrotron radiation in science and industry. Experiments make use of a 2-mile linear accelerator that produces high-energy beams of electrons and positrons for collisions with stationary targets or with one another. Synchrotron radiation research in such fields as materials science, combustion dynamics, environmental pollution control, biology, and medicine is performed with beams of $x$-rays emerging from an electron storage ring known as SPEAR. The use of these facilities is open to researchers from both universities and industries, provided that the results are published in the open literature, such as scientific journals. 
Westinghouse Electric Corporation

Bettis Atomic Power Laboratory

Dr. D. R. Connors, Manager

Operations Training

P.O. Box 79

West Mifflin, PA 15122-0079

(412) 476-6843

Fax: (412) $476-5151$

Established in 1949, it is devoted exclusively to the Naval Nuclear Propulsion Program and includes two sites. Bettis, the principal site, performs research and development of naval nuclear propulsion plants and the Naval Reactors Facility operates prototype naval reactor plants and a facility for examining expended naval reactor cores.

\section{Power Marketing Administrations}

Markets hydroelectric power generated at Federal multipurpose dams operated by the Army Corps of Engineers and the Bureau of Reclamation.

\section{Alaska Power Administration}

Rodney L. Adelman, Administrator U.S. Department of Energy

Room 8G-027, Forrestal Building 1000 Independence Avenue, S.W. Washington, DC 20585

(202) 586-2008

Nicki J. French, Assistant Administrator 2770 Sherwood Lane, Suite 2B Juneau, AK 99801-8545

(907) 586-7026

Fax: (907) 586-7270

237

Bonneville Power Administration

Randall W. Hardy, Administrator

P.O. Box 3621

Portland, OR 97208

(503) 230-3000

Fax: (503) 230-4576

BPA Washington, DC, Office

Stephen J. Wright, Vice President

Room 8G-061, Forrestal Building

(202) 586-5640

238 Southeastern Power Administration

Charles A. Borchardt, Administrator

2 South Public Square

Samuel Elbert Building

Elberton, GA 30635-2496

(706) 213-3800

Fax: (706) 213-3884
Southwestern Power Administration

Michael A. Deihl, Administrator

P.O. Box 1619

Tulsa, OK 74101

(918) 595-6601

Fax: (918) 595-6758

Washington, DC, Office

Barbara Turpen, Liaison Office

Room 8E-027, Forrestal Building

(202) 586-2008

240 Western Area Power Administration

J. M. Shafer, Administrator

P.O. Box 3402

1627 Cole Boulevard

Golden, CO 80401

(303) 231-1513

\section{Washington, $D C$, Office}

Joel K. Bladow, Assistant Administrator Room 8G-027, Forrestal

(202) 586-5581 


\section{Federal Government Agencies}

\section{Department of Agriculture}

\section{Economic Research Service}

Natural Resources and Environment Division Production Management and Technology Branch 1301 New York Avenue, N.W.

Room 424

Washington, DC 20005-4788

Mohinder Gill

Agriculture Economist (202) 219-0447

Provides current and historical statistics on energy use, prices, and expenditures in agriculture by fuel source, such as gasoline, diesel, liquefied petroleum gas, fuel oil, etc. Provides information on grain-based fuel alcohol, including supply demand, economics, capacity, imports, and energy-related legislation, particularly that affecting alcohol fuels.

\section{Forest Service}

U.S. Department of Agriculture

P.O. Box 96090

Washington, DC 20090-6090

Barbara Weber, Associate Deputy

Chief for Research

(202) 205-4507

Gray Reynolds, Deputy Chief for the National Forest System (202) 205-1523

Joan Comanor, Deputy Chief for State and Private Forestry

(202) 205-1657

Howard Rosen

Energy Coordinator

Forest Products and Harvesting Research

Staff

USDA, Forest Service

201 14th Street, S.W.

Washington, DC 20090-6090

(202) 205-1557

Conducts forest biomass energy-related research. Coordinates research activities with Federal and State agencies, as well as universities. Obtains, analyzes, and projects national statistics on woody biomass supply and use, as well as research in silviculture, harvesting, and utilization. Administers national forest lands in a multiple-use approach that includes sales of industrial wood and personal/ industrial use of fuel wood.
243 Rural Utilities Service

U.S. Department of Agriculture

14th and Independence Avenue, S.W.

Washington, DC 20250

Legislative and Public Affairs Staff

(202) 720-1255

The Rural Utilities Service (RUS), a new agency created in late 1994 by the reorganization of the U.S. Department of Agriculture (USDA) seeks to improve the quality of life in rural America via a variety of economic development programs in the electric, telecommunications, water and waste disposal areas.

It administers electric and telephone loan programs previously handled by the Rural Electrification Administration, which was abolished by the reorganization, and the water and waste disposal loan and grant programs, which were previously in the Rural Development Administration.

RUS provided financial assistance via direct loans, guarantees of loans made by others, approval of loan security arrangements, which permits agency borrowers to obtain financing without a guarantee, grants for emergency water system repairs, technical assistance and replacement and contract technical aid in the water and waste disposal areas.

\section{Department of Commerce}

\section{Bureau of Census}

Foreign Trade Division

Room 2179, FOB 3

Washington, DC 20233

For trade data:

(301) 457-2227

Fax: (301) 457-2647

Provides statistical information on U.S. exports and imports merchandise trade.

\section{Bureau of Economic Analysis 1401 K Street, N.W. Washington, DC 20230 \\ Public Information Office (202) 523-0777}

Plays a major role in the measurement and analysis of U.S. economic activity. Develops, prepares, and interprets the economic accounts of the United States which provide a quantitative view of the economy's production and distribution, as well as the 
use of the Nation's output. Featured economic estimates include GDP, personal income, and the index of leading economic indicators. The Bureau's monthly journal, the Survey of Current Business, is available from GPO. The Bureau's other publications are available through GPO and NTIS.

\section{6}

\author{
Import Administration \\ Office of Capital Goods and International \\ Instruction \\ Main Commerce Building \\ Room 2107 \\ Washington, DC 20230

\section{Mining Machinery Division} \\ (202) $482-0680$
}

Provides industry shipments and trade data of mining machinery.

247 International Trade Administration

14th and Constitution Avenue, N.W.

Room 4045

Washington, DC 20230

Vincent J. Kamenicky, Director

Office of Chemicals and Allied Products

(202) $482-0812$

Fax: (202) $377-8836$

Serves as the principal resource for chemical and petrochemical analysis and information in the Department of Commerce. Monitors the industry structure, production, capacity, prices, and other economic factors, both domestic and international. Analytical results are used both within the Department of Commerce for policy planning and by industry and other Government agencies. Responsible for competitive assessment programs, policy and legislation, and export promotions.

248 Office of Energy, Infrastructure, and Machinery

Andrew Vitali, Director

Room 4409

Washington, DC 20230

(202) $482-0169$

Fax: (202) $482-5361$

Helen Burroughs, Director Energy Division

The primary role is to foster and assist the basic energy fuels industries (coal, oil, natural gas, uranium renewable fuels, and electric power generation) to improve their market competitiveness and participation in international trade.
Catherine Vial

Power Generation Specialist

(202) 482-3492

Monitors trade policy issues and projects relating to the power generation sector (conventional fuels only). Provides counselling to developers, manufacturers and service suppliers. Develops trade policy strategies and initiates export promotion events.

249 National Institute of Standards and

Technology

Gaithersburg, MD 20899

George Lewett, Chief

(301) 975-5500

Gale Smith, Administrative Officer (301) $975-4610$

Provides for evaluation of ideas and inventions to determine their technical and commercial feasibility, energy conservation or supply value, and practicality; formulates recommendations for DOE funding if the technology is promising. Applicants must submit a detailed technical description of the invention and complete the Energy-Related Inventions Evaluation Report Form (NBS-1019); the Review process takes from 2 to 8 months. This Office works in conjunction with the DOE Energy-Related Inventions Program.

\section{National Oceanic and Atmospheric} Administration (NOAA)

National Climatic Data Center

Dr. Kenneth Hadeen, Director

151 Patton Avenue, Room 120

Asheville, NC 28801-5001

For climate data, call:

(704) $271-4800$

Fax: (704) $271-4876$

E-Mail: orders@ncdc.noaa.gov

URL: http://www.ncdc.noaa.gov

Provides, for the cost of reproduction, available climatic data and summaries for sites in or near a locality. More sites record a daily precipitation measurement with some sites having automatic gauges which provide a continuous record of precipitation. At many stations, twenty-four hour high and low temperatures are also recorded. More detailed data are available for many airport sites which are located in major U.S. cities. This data is recorded at hourly intervals and consists of such elements as wind, temperature, humidity, type of weather, atmospheric pressure, visibility, and clouds. Summaries, monthly and annual, are available for 
most sites. In addition, wind tabulations, solar radiation, rainfall event statistics, long term normals, accounts of major storms, satellite and radar images, upper air data, weather charts, heating/cooling degree day data, forecasts and warnings, miscellaneous publications, and special studies are available. Data is variously provided as paper copy, on diskette, on cd-roms, or as downloads from the Internet.

\section{National Technical Information Service (NTIS) 5285 Port Royal Road Springfield, VA 22161 (703) $487-4650$}

This organization is the cornerstone of the U.S. government's structure for Scientific Technical Engineering Information (STEI) dissemination to the public with special emphasis on small business and industry. An agency of the U.S. Department of Commerce, NTIS is the central resource for the public sale of U.S. government-sponsored research results--reports available in various formats. The NTIS user community includes scientists, engineers, business people, librarians, and information specialists in government, academia, and the general public. NTIS is self supporting.

The diversity of the NTIS collection is wide. The NTIS Bibliographic Database consists of reports describing research conducted or sponsored by Federal agencies and their contractors; statistical and business information; audiovisual products; computer software and electronic databases developed by Federal agencies; and technical reports prepared by research organizations worldwide.

The Federal Research in Progress (FEDRIP) Database provides access to information about ongoing federally funded projects in the field of the physical sciences, engineering, and life sciences. More than 10 Federal agencies input data to FEDRIP. The ongoing research announced in FEDRIP is an important component to the technology-transfer process in the United States.

FedWorld, the NTIS electronic information network, provides public access to thousands of government documents, connects to several hundred Federal online systems, and offers instant electronic delivery of selected products from NTIS. NTIS provides both dial-up and Internet access to information from numerous government agencies and programs, at no charge to the public.

On NTIS' Web site, users can easily browse for government-produced information by subject such as business, environment, health and safety, and more. If interests are broader, users simply click to other pages on the NTIS Web site. The NTIS Web site can be found at http://www.ntis.gov.

The major contributors to the NTIS collection are NASA, DOD, DOE, and EPA. In addition, approximately 25 percent of all new titles are from international sources through various exchange agreements. Commercial database suppliers such as Dialog (Knight-Ridder Information Services, Inc.), Questel-Orbit, STN International/Cas and others provide electronic access worldwide to the STE! collected by NTIS.

\section{Department of Defense}

\section{Mobility Energy}

John F. Phillips, Deputy Under Secretary of Defense (Logistics)

3500 Defense Pentagon

Washington, DC 20301-3500

(703) 697-1368

James B. Emahiser

Assistant Deputy Under Secretary of

Defense

(Materiel and Distribution Management)

3500 Defense Pentagon

Washington, DC 20301-3500

(703) 697-9238

James N. Carnes, Assistant for Petroleum

(703) 697-2500

Fax: (703) 693-5773

E-Mail: JCARNES@ACQ.OSD.MIL

\section{Energy Supply Availability and Cost}

Provides policy guidance on energy acquisition and supply methods, including bulk petroleum supply, into plane (contracts for fuel services at commercial airports worldwide), and heating fuel distribution on Military Posts, Camps, and Stations. Improves supply security including energy infrastructure, vulernability and national crisis response actions; Fuels Management information system oversite.

\section{Facility Energy}

John B. Goodman, Deputy Under Secretary for Industrial Affairs and Installations

3300 Defense Pentagon

Room 3E1074

Washington, DC 20301-3300 
Millard E. Carr, P.E.

Director, Energy and Engineering

Suite 208

400 Army Navy Drive

Arlington, VA 22202-2884

(703) 604-6022

Fax: (703) 604-6024

E-Mail: MCARR@ACQ.OSD.MIL

Thomas V. Bee, P.E., Deputy Director (903) 604-6023

E-Mail: TBEE@ACQ.OSD.MIL

\section{Energy Resource Management and Conservation}

Reduces energy use through efficiency investments, incentives, and engineering; develops energy use and management policies that achieve environmental goals; e.g., clean air, clean water, solid and hazardous waste minimization; and develops and cosponsors emerging energy technologies for a variety of security, environmental, and economic goals.

Improves energy acquisition to include the centralized natural gas and coal purchasing; develops electric utility policies on source selection, cogeneration, cost reduction, and demand management to meet clean air goals; manages information to measure progress against goals.

\author{
Defense Fuel Supply Center (DFSC) \\ Col. Loren M. Reno, USAF, Commander \\ 8295 John J. Kingman Road \\ Suite 4950 \\ Fort Belvoir, VA 22060-6222 \\ (703) 767-9706 \\ Fax: (703) 767-9672 \\ Dr. Marshall H. Bailey, III, Deputy \\ Commander \\ (703) $767-9700$ \\ Fax: (703) 767-9672 \\ Capt. Fred C. Chitty, SC, USN \\ Deputy Commander, Business Operations \\ (703) $767-9700$ \\ Fax: (703) 767-9672
}

Provides the Department of Defense and its customers comprehensive energy support in the most effective and economical manner possible. DFSC manages 47 national stock numbers for petroleum products. The products include jet fuels, aviation gasoline, automotive gasoline, heating oils, power generation oil, naval propulsion fuels, lubricants, natural gas, and coal.

DFSC is one of five inventory control points in the Defense Logistics Agency. Providing worldwide fuel support, the Center has four Defense Fuel Regions
(DFR): DFR-Americas, Houston, Texas; DRF-Europe, Wiesbaden, German; DFR-Middle East, Juffair, Bahrain; and DFR-Pacific, Camp Smith, Hawaii.

For more information on the Defense Fuel Supply Center, call 1-800-286-7633 or visit the Center's web site: http://www.dfsc.dla.mil.

\section{Department of Health and Human Services (HHS)}

253 Office of Community Services

Administration for Children and Families Mary Jo Bane, Assistant Secretary 370 L'Enfant Promenade, S.W. Washington, DC 20447 (202) 401-9200

Administers the Low Income Home Energy Assistance Program (LIHEAP) block grants to the States, Indian tribes, and U.S. territories to assist low-income households with home energy costs through heating and cooling assistance, crisis assistance, and weatherization assistance.

\section{Department of Housing and Urban Development (HUD)}

\section{Office of Community Viability}

Robert Groberg, Director

Energy Division

451 7th Street, S.W., Room 7146

Washington, DC 20410

(202) 708-0614 Ext. 4642

Fax: (202) 708-3363

Serves as HUD's principal coordinator for energy activities and provides advice and staff support on energy matters affecting State and local governments and the general public; provides technical assistance to State and local governments in achieving the energy objectives of programs administered by the Department, including public housing, the Community Development Block Grant Program and the Affordable Housing Act programs.

Prepares the HUD Five-Year Energy Plan, administers and participates in demonstrations, feasibility studies, and cooperative efforts with the Department of Energy and other agencies in such diverse areas as energy efficiency of buildings, economic/community development, district heating, municipal wasteto-energy systems, energy and the elderly, and sustainable development. 
P.O. Box 6091

Rockville, MD 20850

(301) 251-5154

(800) 245-2691

Fax: (301) 251-5767

E-Mail: huduser@aspensys.com

URL: http://www.huduser.org

Operates a computer-based information service. Provides literature searches from HUD's data base, summaries of HUD research results, special products, and document distribution service. In the data base collection, energy and utilities information is included. Other information includes, but is not limited to, building technology, community development/public finance, elderly and handicapped, environmental research, housing finance, housing management, and housing programs. HUD USER does charge for service and handling of information and documents

\section{Department of Interior}

\section{6}

\author{
Minerals Management Service \\ Cynthia L. Quarterman, Director \\ 1849 C Street, N.W., Room 4210 \\ Washington, DC 20240 \\ (202) 208-3500
}

Responsible for the offshore leasing program, resource evaluation, and classification functions; environmental review of leasing activities; regulation of operations and lease management; and inspection and enforcement activities for all leasable minerals on the Outer Continental Shelf (OCS). Responsible for the collection of all royalty payments, rentals, bonus payments, fines, penalties, and assessments and for other revenues due the Federal Government and Indian lessors as monies or royalties-in-kind from the extraction of mineral resources from Federal and Indian lands on-shore and from the leasing and extraction of mineral resources on the OCS.

\section{Office of Surface Mining Reclamation and Enforcement \\ Gene Krueger, Chief \\ Reclamation Support Division, Room 120 \\ 1951 Constitution Avenue, N.W. \\ Washington, DC 20240 \\ (202) 208-2937 \\ Fax: (202) 219-3100}

Formulates policy for State, Federal, and Indian Abandoned Mine Land (AML) reclamation programs, and develops annual work plans. Develops grant distributions to the States and Tribes from the AML Reclamation Fund. Provides guidance for monitoring and evaluating Federal and State/Tribal AML programs for establishing programmatic requirements for AML grants and for administering emergency reclamation responsibilities. Maintains an inventory and tracking system for projects funded from the AML Reclamation Fund. Coordinates the Office of Surface Mining Reclamation and Enforcement's Value Engineering activities.

258

\author{
U.S. Geological Survey (USGS) \\ Geologic Inquiries Group \\ 907 National Center \\ Reston, VA 22092 \\ (703) 648-4383 \\ Fax: (703) 648-6645
}

Answers questions on all aspects of geology such as earthquakes, volcanoes, energy resources, the geology of specific areas, and geologic maps and mapping. Information on geologic map indexes and a limited number of copies are also available. Written and telephone requests are handled by this Office or are referred to the appropriate information source.

\author{
Distribution Branch \\ Map Sales \\ Box 25286, DFC \\ Denver, CO 80225 \\ (303) 236-7477
}

Distributes maps of energy resources in the United States. The maps vary in price. Contact this office for an index of map titles and ordering information. Topographic maps are available.

\section{Information Systems Division 802 National Center Reston, VA 22092 \\ Earth Science Data Directory Project Manager (703) $648-7112$}

Offers online access to earth-science and natural-resource data bases. A directory is also available on compact disc. Data bases referenced in the directory include those concerned with the geologic, hydrologic, cartographic, and biologic sciences. References to data bases that support the protection and management of natural resources are also included. Geographic, sociologic, economic, and demographic data bases are among those cataloged. Arctic region data base entries are included in the Arctic Environmental Data Directory as a subset. The directory is the repository of information on Department of Interior data bases related to interagency global change activities. A full range of data sources offer potential leads to base and/or overlay input for geographic information system (GIS) applications. 
Department of Labor

\section{Bureau of Labor Statistics}

Consumer Price Index

2 Massachusetts Avenue, N.E.

Washington, DC 20212

Bob Adkins, Economist

Natural Gas, Electricity, Fuel Oil

(202) 606-6985

Joe Chelena, Economist

Gasoline

(202) 606-6982

Provides monthly prices for residential consumption of natural gas, electricity, fuel oil, and gasoline. Prices and indexes are calculated for the U.S., 15 cities, and Standard Metropolitan Statistical Areas (SMSA), reflecting different geographic areas and population categories. Price indices for natural gas, fuel oil, gasoline, and other fuels are also available.

260 Division of Monthly Industry Employment Statistics

2 Massachusetts Avenue, N.E., Suite 4860 Washington, DC 20212

Lois Plunkert, Branch Chief (202) 606-6555

Compiles and publishes monthly statistics on the number, work hours, and earnings of employees in various industries, including energy industries.

\section{Mine Safety and Health Administration (MSHA) \\ Office of Information \\ Wayne Veneman, Director \\ 4015 Wilson Boulevard, Room 601 \\ Arlington, VA 22203 \\ (703) $235-1452$}

Provides information on a wide variety of mine safety topics. Responsible for responding to information requests from media and the public. Various fact sheets are available on such subjects as coal mine safety and health activities. Provides inquiry assistance in conjunction with other MSHA policy, and education programs related to mine safety and training.

\section{Department of Transportation}

262 Office of Environment, Energy, and Safety 4007 th Street, S.W.

Room $9216 \mathrm{C}$

Washington, DC 20590

Donald J. Igo, Assistant for Energy Policy (202) 366-0783

Provides support for the development of transportation energy policy and provides review of major energy policy issues arising in various Department of Transportation programs.

\section{Office of Regulatory Affairs}

4007 th Street, S.W., Room 9217

Washington, DC 20590

Nancy Ebersol, Program Analyst

(202) 366-0353

Provides information from the interim (1974) and final (1975) reports to Congress on the operation and effects of daylight saving time experiments in energy use and on other factors.

264 Federal Highway Administration

Office of Highway Information Management Gary E. Maring, Director 4007 th Street, S.W.

Washington, DC 20590 (202) 366-0180

Compiles and publishes statistics on highway use of motor fuels, including total use of gasoline; vehicle registration and driver's licenses issued; financing of Federal, State and local highway systems; mileage of roads and streets, including type of pavement; traffic and travel characteristics, including vehicle-miles traveled. Most data are by State. Conducts the Nationwide Personal Transportation Survey every 5 years.

265 National Highway Traffic Safety

Administration

Office of Enforcement and Emergency

Services

400 7th Street, S.W., Room 5119

Washington, DC 20590

Susan D. Ryan, Chief

Emergency Medical Services

(EMS) Division, NTS-40

(202) 366-4299

Fax: (202) 366-7721

This Office is comprised of two Divisions: Emergency Medical Services (EMS) and Police Traffic Services. EMS provides leadership, training, research 
and development of programs in support of the overall mission of the National Highway Traffic Safety Administration (NHTSA): to save lives, prevent injuries, and reduce traffic-related and other economic costs.

The Police Traffic Services Division provides leadership, training, research and development of programs in support of NHTSA's mission to make America's highways safer. These initiatives are designed to assist State and local efforts to strengthen the performance and image of law enforcement agencies in the United States. The Division provides extensive leadership and direction in the development efforts that address the issues of speed, impaired driving and the use of occupant restraints and safety equipment.

\section{6}

\author{
Research and Special Programs \\ Administration \\ Office of Hazardous Materials \\ Planning and Analysis \\ 400 7th Street, S.W., Room 8112 \\ Washington, DC 20590

\section{Kevin Coburn} \\ Information Systems Manager \\ information Systems, DHM-63 \\ (202) 366-4555
}

Serves as a centralized computer-maintained management information system supporting the multimodal transportation of hazardous materials. The Hazardous Materials Information System (HMIS) provides direct retrieval, through six major subsystems, of the available information on incident data, inspection/ enforcement results, information on Hazardous Materials Registration Program, interpretation of regulations, status of approvals, and status of exemptions. Requests for information will be honored. Limited direct access can also be arranged.

\section{Department of Treasury}

Bureau of Alcohol, Tobacco, and Firearms (ATF)

Virginia O'Brien, Chief Public Information Branch

Washington, DC 20226

(202) $927-8500$

Maintains pamphlets and fact sheets about the Bureau's history and responsibilities. Provides ATF news releases and information about Federal laws and ordinances that affect trade in and licensing of alcohol, tobacco, firearms, and explosives.
Internal Revenue Service

Department of the Treasury

Provides information on tax problems including energy-related taxes and tax credits. For the toll-free number in your locality, consult the telephone directory under "U.S. Government, Department of the Treasury, Internal Revenue Service."

\section{Statistics of Income Division}

Internal Revenue Service 500 North Capitol Street, N.W.

P.O. Box 2608

Washington, DC 20013

Daniel F. Skelly, Director (202) 874-0700

Produces statistics on energy-related industries and on the Nonconventional Source Fuel Credit. 


\section{Federal Government Legislative Branch}

United States Senate

\section{Committee on Energy and Natural Resources 364 Senate Dirsken Office Building Washington, DC 20510-6150 (202) 224-4971}

Consists of 20 Senators responsible for all proposed legislation, messages, petitions, memorials, and other matters relating to the following subjects: (I) coal production, distribution, and utilization; (2) energy policy; (3) energy regulation and conservation; (4) energy related aspects of deepwater ports; (5) energy research and development; (6) extraction of minerals from oceans and Outer Continental Shelf lands; (7) hydroelectric power, irrigation, and reclamation; (8) mining education and research; (9) mining, mineral lands, mining claims, and mineral conservation; (10) national parks, recreation areas, wilderness areas; wild and scenic rivers, historical sites, military parks and battlefields, and the public domain; preservation of prehistoric ruins and objects of interest; (11) naval petroleum reserves in Alaska; (12) nonmilitary development of nuclear energy; (13) oil and gas production and distribution; (14) public lands and forests, including farming and grazing thereon, and mineral extraction therefrom; (15) solar energy systems; (16) territorial possessions of the United States, including trusteeships.

\section{Subcommittee on Energy Research and Development 364 Senate Dirsken Office Building Washington, DC 20520-6154 (202) 224-4971}

Responsible for oversight and legislative issues for nuclear research and development; coal and synfuels research and development; nuclear and nonnuclear energy commercialization projects; nuclear fuel cycle policy, including uranium resources; new technologies research and development; nuclear facilities siting; and breeder reactor development.

\section{Subcommittee on Public Lands, National Parks and Forests 364 Senate Dirsken Office Building Washington, DC 20510-6158 (202) 224-4971}

Responsible for oversight and legislative issues for the public lands administered by the Bureau of Land Management; National Forest System; National Park System; National Wilderness Preservation System; Wild and Scenic Rivers System; National Trails System; establishment of wildlife refuges on public lands; Alaska Native Claims Settlement Act; Alaska National Interest Lands Conservation Act; reserved water rights; military land withdrawals; national recreation areas; national monuments; historic sites; military parks and battlefields; Land and Water Conservation Fund; historic preservation; renewable resources; outdoor recreation resources; and on the public domain, preservation of prehistoric ruins and objects of interest.

\section{Subcommittee on Water and Power 364 Senate Dirsken Office Building Washington, DC 20510-6156} (202) 224-4971

Responsible for oversight and legislative issues for irrigation; reclamation projects, including related flood control purposes; power marketing administrations (e.g., Bonneville Power, Alaska Power, Southwestern Power, Western Area Power; Southeastern Power); energy development impacts on water resources; groundwater resources and management; small power producers; hydroelectric power; and low lead hydro.

\section{United States House of Representatives}

\section{Committee on Commerce}

2125 Rayburn House Office Building

Washington, DC 20515

(202) 225-2927

This Committee's responsibilities are as follows: (1) biomedical research and development; (2) consumer affairs and consumer protection; (3) health and health facilities, except health care supported by payroll deductions; (4) interstate energy compacts; (5) interstate and foreign commerce generally; (6) measures relating to the exploration, production, storage, supply, marketing, pricing, and regulation of energy resources, and other unconventional or renewable energy resources; (7) measures relating to the conservation of energy resources; (8) measures relating to energy information generally; (9) measures relating to the generation and marketing of power (except by federally chartered or Federal regional power marketing authorities), the reliability and interstate transmission of, and ratemaking for, all power, and the siting of generation facilities; except the installation of interconnections between Government water-power projects; (10) measures relating to general management of the Department of Energy, and the management and all functions of the Federal Energy Regulatory Commission; (11) national energy policy generally; (12) public health and quarantine; (13) regulation of the domestic nuclear energy industry, including regulation of research and 
development reactors and nuclear regulatory research; (14) regulation of interstate and foreign communications; (15) securities and exchanges; and (16) travel and tourism.

The Committee shall have the same jurisdiction with respect to regulation of nuclear facilities and the use of nuclear energy as it has with respect to regulation of nonnuclear facilities and the use of nonnuclear energy. In addition to its legislative jurisdiction under the preceding provisions of this paragraph (and its general oversight functions under clause 2(b) (1), such committee shall have the special oversight functions provided for in clause (3)(h) with respect to all laws, programs, and Government activities affecting nuclear and other energy, and nonmilitary nuclear energy and research and development including the disposal of nuclear waste.

\section{Subcommittee on Energy and Power} 2125 Rayburn House Office Building Washington, DC 20515-6120

(202) 225-2927

Responsible for national energy policy; fossil energy and renewable energy resources; synthetic fuels and energy conservation; energy regulation, and utilization; utility issues and regulation of nuclear facilities; and, all laws, programs and Government activities affecting matters of nuclear energy and waste; mining, oil and gas, and coal combustion wastes. 


\section{Independent Agencies}

\section{Environmental Protection Agency}

\section{6}

\author{
Indoor Air Quality Information Clearinghouse \\ P.O. Box 37133 \\ Washington, DC 20013-7133 \\ (800) 438-4318 \\ (301) $585-9020$ \\ Fax: (301) 588-3408
}

A central source of information in indoor air quality, created and supported by the U.S. Environmental Protection Agency. The purpose of the office is to answer questions about indoor air pollution and or make referrals.

277 Office of Air Quality Planning and Standards Information Transfer and Program Integration Division Information Management Group, (MD-12) Research Triangle Park, NC 27711

Jonathan Miller, Data Administrator Air Quality Subsystems

(919) $541-3330$

Virginia Ambrose, Coordinator

Data Retrievals

(919) 541-5454

Jan Kleeman, Data Administrator

Air Facility Subsystems

(919) $541-3450$

Provides emissions data and background information on air quality and air facility subsystems.

\section{Office of Federal Activities \\ Dawn Roberts \\ 401 M Street, S.W., Room 2119M \\ A-104 \\ Washington, DC 20460 \\ (202) 564-7153}

Maintains the Council on Environmental Quality filing system of Environmental Impact Statements (EIS's) that have been submitted by sponsoring agencies. It also controls the records of all EIS reviews by the Environmental Protection Agency.

\section{U.S. International Trade Commission}

Energy, Chemicals, and Textiles Division 500 E Street, S.W.

Washington, DC 20436

(202) 205-3342

Energy related activities include the monitoring of production, sales, and international trade of petroleum, natural gas, coke and coal, uranium, and electricity. Follows developments in biomass, solar and hydropower for energy production, and collects and publishes data on U.S. production and sales of all synthetic organic chemicals, including alternate energy sources, such as alcohols and oxygenates.

\section{Nuclear Regulatory Commission}

\author{
Office of Public Affairs \\ Washington, DC 20555 \\ (301) 415-8200 \\ Fax: (301) 415-2234 \\ E-Mail: opa@nrc.gov
}

Serves as a public inquiry point for information on licensing (including decommissioning) of commercial nuclear power plants and other nuclear facilities and the possession and use of nuclear materials for medical, industrial, educational, and research purposes; inspections and investigations designed to assure that licensed activities are conducted in compliance with the Agency's regulations and other requirements; confirmatory research in the areas of safety, safeguards, and environmental assessment and the establishment of regulations, standards, and guidelines governing the civilian use of nuclear facilities and materials; safeguarding of nuclear facilities and materials from diversion or sabotage; implementation of Agency responsibilities under the Nuclear Waste Policy Act of 1982 (high-level radioactive wastes), as amended in 1987, the Low-Level Radioactive Waste Policy Act of 1980, as amended in 1985, and the Uranium Mill Tailings Radiation Control Act of 1978; and packaging of radioactive materials for transport.

281 Tennessee Valley Authority

Forest Resources Development Program Dennis Curtin, Forestry Specialist

Natural Resources Building

Norris, TN 37828

(615) 632-1635

The Forest Industry Data System (FIND) contains information on wood residue production and use by county, the location and size of wood fuel combustion facilities, and electrical production capacity. 


\section{U.S. General Accounting Office (GAO)}

Victor S. Rezendes, Director

Energy, Resources and Science Issue Area

Resources, Community, and

Economic Development Division

Room 2440

441 G Street, N.W.

Washington, DC 20548

(202) 512-3841

Barry Hill, Associate Director

(202) $512-9775$

Allen Li, Associate Director

(202) 512-3600

Bernice Steinhardt, Associate Director (202) 512-6543

\author{
Publications Ordering \\ P.O. Box 6015 \\ Gaithersburg, MD 20884-6015
}

The GAO is a nonpartisan legislative branch agency that assists Congress, its communities, and members in their legislative and oversight work. GAO's Energy Issue Area conducts in-depth studies of the production, regulation, and consumption of all forms of energy. Aspects of GAO's energy work include evaluating the effectiveness of energy security policies and programs; the management of energy research and development programs and nuclear waste disposal programs; the safety of defense and commercial nuclear facilities; and the procedures and controls governing energy programs. Publications available include Energy and Science: Five Year Bibliography 1990-1994 (GAO/RCED-96-007W), available only on the Internet. Also available are GAO's Monthly List of Reports and Testimonies and GAO's Annual Index. Orders may be placed by calling (202) 512-6000, by using fax number (301) 258-4066, or by writing to the above publications address. The first copy of each GAO report and testimony is free. Additional copies are $\$ 2.00$.

\section{U.S. Government Printing Office}

Superintendent of Documents

Washington, DC 20402

(202) 783-3238

Handles the public sale of Federal Government publications, including selected DOE and EIA statistical, technical, and educational publications. General publications on energy and other areas of interest to the consumer are also available. The bookstores quote prices and availability on phone and mail requests. The bookstores respond to requests from all 50 States and from requestors in foreign countries. Telephone orders are accepted only from those with a GPO account, Visa, Mastercard; remittance in the form of a check or money order must accompany all other orders. Free subject bibliographies are available on request.

\section{GPO Bookstores and Retail Sales Branch}

\author{
Atlanta Bookstore \\ First Union Plaza \\ 999 Peachtree Street, N.E., Suite 120 \\ Atlanta, GA 30309 \\ (404) 347-1900 \\ Fax: (404) 347-1897
}

Birmingham Bookstore

$O$ 'Neill Building

2021 3rd Avenue North

Birmingham, AL 35203

(205) 731-1056

Fax: (205) 731-3444

\section{Boston Bookstore}

Thomas P. O'Neill Federal Building

10 Causeway Street, Room 169

Boston, MA 02222

(617) 720-4180

Fax: (617) $720-5753$

Chicago Bookstore

One Congress Center, Suite 124

401 South State Street

Chicago, IL 60605

(312) 353-5133

Fax: (312) 353-1590

Cleveland Bookstore

Room 1653, Federal Building

1240 East 9 th Street

Cleveland, OH 44199

(216) 522-4922

Fax: (216) 522-4714

Columbus Bookstore

Room 207, Federal Building

200 N. High Street

Columbus, $\mathrm{OH} 43215$

(614) 469-6956

Fax: (614) 469-5374

Dallas Bookstore

Room 1C50, Federal Building

1100 Commerce Street

Dallas, TX 75242

(214) 767-0076

Fax: (214) 767-3239 
Denver Bookstore

Room 117, Federal Building

1961 Stout Street

Denver, CO 80294

(303) 844-3964

Fax: (303) 844-4000

Detroit Bookstore

Suite 160, Federal Building

477 Michigan Avenue

Detroit, MI 48226

(313) 226-7816

Fax: (313) 226-4698

Houston Bookstore

Texas Crude Building

801 Travis Street

Houston, TX 77002

(713) 228-1187

Fax: (713) $228-1186$

Jacksonville Bookstore

100 West Bay Street, Suite 100

Jacksonville, FL 32202

(904) 353-0569

Fax: (904) 353-1280

Kansas City Bookstore

120 Bannister Mall

5600 East Bannister Road

Kansas City, MO 64137

(816) 765-2256

Fax: (816) 767-8233

Los Angeles Bookstore

ARCO Plaza, C-Level

505 South Flower Street

Los Angeles, CA 90071

(213) 239-9844

Fax: (213) 239-9848

Main Bookstore

710 North Capitol Street, N.W.

Washington, DC 20401

(202) 512-0132

Fax: (202) 512-1355

McPherson Square Bookstore

1510 H Street, N.W.

Washington, DC 20005

(202) 653-5075

Fax: (202) 376-5055

Milwaukee Bookstore

The Reuss Federal Plaza

310 W. Wisconsin Avenue

Milwaukee, WI 53202

(414) 297-1304

Fax: (414) 297-1300
New York Bookstore

Room 110, Federal Building

26 Federal Plaza

New York, NY 10278

(212) 264-3825

Fax: (212) 264-9318

Philadelphia Bookstore

Robert Morris Building

100 North 17 th Street

Philadelphia, PA 19103

(215) 636-1900

Fax: (215) 636-1903

Pittsburgh Bookstore

Room 118, Federal Building

1000 Liberty Avenue

Pittsburgh, PA 15222

(412) 644-2721

Fax: (412) 644-4547

Portland Bookstore

1305 S.W. First Avenue

Portland, OR 97201

(503) 221-6217

Fax: (503) 225-0563

Pueblo Bookstore

Norwest Banks Building

201 W. 8th Street

Pueblo, CO 81003

(719) 544-3142

Fax: (719) 544-6719

San Francisco Bookstore

Marathon Plaza, Room 141-S

303 Second Street

San Francisco, CA 94107

(415) $512-2770$

Fax: (415) 512-2776

Seattle Bookstore

Room 194, Federal Building

915 Second Avenue

Seattle, WA 98174

(206) 553-4270

Fax: (206) 553-6717 


\section{State Governor Offices and Energy Agencies}

The following lists for each State the Governor, the State Energy Office or equivalent, State Oil and Gas Agency, State Geologist, and the Public Utility Commission or equivalent. Public utility commissions (sometimes referred to as public service commissions) are responsible for the economic regulation of utilities. The goal of regulation is to ensure provision of safe and reliable service at just, reasonable and sufficient rates.

\section{Alabama}

Governor Fob James, Jr.

State Capitol

600 Dexter Avenue

Montgomery, AL 36130

(334) 242-7100

\section{State Energy Office}

Martha Mclnnis, Division Chief

Department of Economic and Community

Affairs

Science Technology and Energy Division

P.O. Box 5690

Montgomery, AL 36103-5690

(334) 242-5292

Fax: $\{334\}$ 242-0552

State Geologist

Donald F. Oltz, Jr.

Geological Survey of Alabama

420 Hackberry Lane

P.O. Box 0

Tuscaloosa, AL 35486-9780

(205) 349-2852

Fax: (205) 349-2861

State Oil and Gas Agency

Donald F. Oltz, Jr.

Oil and Gas Supervisor

State Oil and Gas Board

P.O. Box 0

Tuscaloosa, AL 35486-9780

(205) 349-2852

Fax: (205) 349-2861

URL: ogbweb.gsa.tuscaloosa.al.us

Public Service Commission

Walter L. Thomas, Jr., Secretary

Montgomery Street

P.O. Box 991

Montgomery, AL 36101-0991

(334) 242-5218
285 Alaska

Governor Tony Knowles

P.O. Box 110001

Juneau, AK 99811-0001

(907) 465-3500

Fax: (907) 465-3532

\section{State Energy Office}

Robert Breen

Alaska Housing Finance Corporation

520 East 34th Avenue

Anchorage, AK 99503

(907) 561-1900

\author{
Alaska Department of Commerce and \\ Regional Affairs \\ Percy Frisby \\ Energy Division \\ 333 West 4th Avenue, Suite 220 \\ Anchorage, AK 99519 \\ (907) 269-4500 \\ Fax: (907) 269-4645 \\ State Geologist and Director \\ Milton A. Wiltse \\ Department of Natural Resources \\ Division of Alaska Geological and \\ Geophysical Survey \\ 794 University Avenue, Suite 200 \\ Fairbanks, AK 99709-3645 \\ (907) 451-5005 \\ Fax: (907) 451-5050
}

\author{
Alaska Department of Administration \\ David Johnston, Chairman \\ Alaska Oil and Gas Conservation \\ Commission \\ 3001 Porcupine Drive \\ Anchorage, AK 99501-3192 \\ (907) 279-1433
}

\author{
Alaska Department of Environmental \\ Conservation \\ Division of Information and Administrative \\ Services \\ 410 Willoughby Avenue, Suite 105 \\ Juneau, AK 99801 \\ (907) 465-5010
}

Alaska Department of Natural Resources Division of Oil and Gas

3601 C Street, Suite 1380

Anchorage, AK 99503-5948

(907) 762-2547 
Alaska Department of Revenue

Oil and Gas Audit Division

$500 \mathrm{~W} 7$ th Avenue, Suite 570

Anchorage, AK 99501-3557

(907) 276-1363

Alaska Public Utilities Commission Robert A. Lohr, Executive Director 1016 West 6th Avenue, Suite 400 Anchorage, AK 99501

(907) 276-6222

Fax: (907) 276-0160

E-Mail: apuc@apuc.ak.net

\section{American Samoa}

Governor A. P. Lutali

Governor's House

Pago Pago, AS 96799

011 (684) 633-4116

State Energy Office

Reupena Tagaloa, Director

ASPA/Territorial Energy Office

Samoa Energy House, Tafuna

P.O. Box PPB

Pago Pago, AS 96799

011 (684) 699-1101

Fax: 011 (684) 699-2835

\section{Arizona}

Governor Fife Symington

$1700 \mathrm{~W}$. Washington Street

Phoenix, AZ 85007

(602) 542-4331

Fax: (602) 542-1381

\section{State Energy Office}

Amanda Ormond, Director

Arizona Department of Commerce

3800 North Central Avenue, Suite 1200

Phoenix, AZ 85012

(602) 280-1402

Fax: (602) 280-1445

State Geologist

Larry D. Fellows

Arizona Geological Survey

$416 \mathrm{~W}$. Congress Street, Suite 100

Tucson, AZ 85701-1315

(520) 770-3500

Fax: (520) 770-3505

\section{Corporation Commission}

James Matthews, Executive Secretary

Arizona Corporation Commission

$1200 \mathrm{~W}$. Washington

Phoenix, AZ 85007-2996

(602) 542-43931
Arkansas

Governor Mike Huckabee

State Capitol Room 250

Little Rock, AR 72201

(501) 682-2345

State Energy Office

Morris Jenkins, Director

Arkansas Energy Office

One State Capitol Mall

Little Rock, AR 72201

(501) 682-7377

Fax: (501) 682-2703

State Geologist

William V. Bush, Director and

State Geologist

Arkansas Geological Commission

3815 West Roosevelt Road

Little Rock, AR 72204

(501) 296-1877

Fax: (501) 663-7360

State Oil and Gas Agency

William E. Wright, Director

Oil and Gas Commission

P.O. Box 1472

EI Dorado, AR 71731-1472

(501) 862-4965

Fax: (501) 862-8823

Public Service Commission

Jerrell Clark, Director

Arkansas Public Service Commission

1000 Center Street

P.O. Box 400

Little Rock, AR 72203-0400

(501) 682-1794

California

Governor Pete Wilson

State Capitol

Sacramento, CA 95814

(916) $445-2841$

State Energy Office

Charles R. Imbrecht, Chairman

California Energy Commission

1516 9th Street

Sacramento, CA 95814

(916) 654-5000

Fax: (916) 654-4420 
State Geologist

James F. Davis

California Geological Survey

Department of Conservation

Division of Mines and Geology

801 K Street, MS 12-30

Sacramento, CA 95814-3531

(916) 445-1923

Fax: (916) 445-5718

State Oil and Gas Agency

William F. Guerard, Jr.

State Oil. and Gas Supervisor

Department of Conservation

Division of Oil, Gas, and Geothermal

Resources

801 K Street, MS 20-20

Sacramento, CA $95814-3530$

(916) $445-9686$

California Public Utilities Commission Wesley M. Franklin, Executive Director 505 Van Ness Avenue, Room 5222

San Francisco, CA 94102

(415) 703-3808

Colorado

Governor Roy Romer

136 State Capitol

Denver, CO 80203-1792

(303) $866-2471$

State Energy Dffice

Wade Buchanan, Director

Colorado Office of Energy Conservation

1675 Broadway, Suite 1300

Denver, CO 80202-4613

(303) 620-4292

Fax: (303) $620-4288$

State Geologist

Colorado Geological Survey

1313 Sherman Street, Room 715

Denver, CO 80203

(303) 866-2611

Fax: (303) 866-2461

Oil and Gas Conservation Commission

1580 Logan Street, Suite 380

Denver, CO 80203

(303) 894-2100

Fax: (303) 894-2109

Public Utilities Commission

R. Brent Alderfer, Commissioner Logan Tower OL2, Logan Street

Denver, CO 80203

(303) 894-2070

Fax: (303) 894-2065
Connecticut

Governor John G Rowland

210 Capitol Avenue

Hartford, CT 06106

(860) $566-4840$

State Energy Office

Allan Johanson

Policy Development and Planning Division

Energy Unit

P.O. Box 341441, MS-52ENR

Hartford, CT 06134-1441

(860) 418-1441

Fax: $(860) 418-6297$

State Geologist

Richard C. Hyde

Connecticut Geological Survey

Department of Environmental Protection

Natural Resources Center

79 Elm Street, Store Level

Hartford, CT 06106-5127

(860) 424-3540

Fax: (860) 424-4058

Department of Public Utility Control Louis Rickard, Chief of Research and Policy Analysis

1 Central Park Plaza

New Britain, CT 06051

(860) 827-2601

292 Delaware

Governor Thomas Carper

Legislative Hall

William Penn Street

Dover, DE 19901

(302) 739-4101

\section{State Energy Office}

Charlie T. Smisson, Jr., Energy Program

Administrator

Division of Facilities Management

P.O. Box 1401, O'Neill Building

Dover, DE 19903

(302) 739-5644

Fax: (302) 739-6148

URL: CSMISSON@STATE.DE.US

State Geologist

Robert R. Jordan

Delaware Geological Survey

University of Delaware

DGS Building

Newark, DE 19716-7501

(302) $831-2833$

Fax: (302) 831-3579 
Delaware Public Service Commission Bruce H. Burcat, Executive Director 1560 South Dupont Highway

Dover, DE 19901

(302) $739-4247$

Fax: (302) 739-9849

293

District of Columbia

Mayor's Office

Marion Barry

2000 14th Street, N.W.

Washington, DC 20009

(202) $727-6310$

City Energy Office

Charles J. Clinton, Director

District of Columbia Energy Office

2000 14th Street, N.W., Suite 300E

Washington, DC 20009

(202) 673-6750

Fax: (202) 673-6725

Public Service Commission

Phylicia Fauntleroy Bowman, Executive

Director

717 14th Street, N.W.

Washington, DC 20005

(202) 626-5100

Fax: (202) 393-1389

\section{Fiorida}

Governor Lawton Chiles

The Capitol

Tallahassee, FL 32399-0001

(904) 488-2272

\section{State Energy Office}

William J. Tait, Director

Department of Community Affairs

2555 Shumard Oak Boulevard

Tallahassee, FL 32399-2100

(904) 488-2475

Fax: (904) 922-5623

\section{State Geologist}

Walter Schmidt

Florida Geological Survey

Gunter Building

903 W. Tennessee Street

Tallahassee, FL 32304-7700

(904) 488-4191

Fax: (904) 488-8086

Public Service Commission

William D. Talbott, Executive Director

2540 Shumard Oak Boulevard

Tallahassee, FL 32399-0850

(904) 488-7463
Georgia

Governor Zell Miller

203 State Capitol

Atlanta, GA 30334

(404) 656-1776

\section{State Energy Office}

Paul Burks

Division of Energy Resources

Equitable Building

100 Peachtree Street, N.W.

Atlanta, GA 30303

(404) 656-0939

Fax: (404) 656-6416

State Geologist

William H. McLemore

Georgia Geologic Survey

Suite 400

19 Martin Luther King Jr. Drive, S.W.

Atlanta, GA 30334

(404) 656-3214

Public Service Commission

B. B. Knowles, Director of Utilities

244 Washington Street, S.W., Suite 155

Atlanta, GA 30334

(404) 656-4501

296 Guam

Governor Carl T. C. Gutierrez

Executive Office

P.O. Box 2950

Agana, GU 96910

(671) 472-8931

Fax: (671) 475-6462

URL: http://www.gov.gu

State Energy Office

Fred P. Camacho, Director

Guam Energy Office

1504 East Sunset Boulevard

Tiyan, GU 96913

(671) 477-0557

Fax: (671) 477-0589

297

Hawaii

Governor Benjamin J. Cayetano

State Capitol

Honolulu, $\mathrm{HI} 96813$

(808) 548-0034

Fax: (808) 587-3820 
State Energy Office

Maurice H. Kaya, Administrator

Energy, Resources, and Technology Division

Department of Business, Economic

Development and Tourism

P.O. Box 2359

Honolulu, HI 96804

(808) $587-3812$

Fax: $(808) 587-3820$

\section{State Geologist}

Manabu Tagomori

Hawaii Geological Survey

Department of Land and Natural Resources

Division of Land and Water Development

P.O. Box 373

Honolulu, HI 96809

(808) 587-0230

Fax: (808) 587-0283

Public Utilities Commission

Yukio Naito, Chairman

465 S. King Street, \#103

Honolulu, HI 96813

(808) $586-2020$

Idaho

Governor Philip E. Barr

State Capitol

Boise, ID 83720-0034

(208) 334-2100

\section{State Energy Office}

Karl Dreher, Director

Idaho Department of Water Resources

1301 North Orchard

Boise, ID 83706

(208) $327-7900$

Fax: (208) 327-7866

\section{State Geologist}

Earl H. Bennett

Idaho Geological Survey

Room 332, Morrill Hall

University of Idaho

Moscow, ID 83843

(208) 885-7991

Fax: (208) $885-5826$

Public Utilities Commission

Stephanie Miller, Administrator

Utilities Division

P.O. Box 83720

Boise, ID $83720-0074$

(208) $334-0366$
Illinois

Governor Jim Edgar

State Capitol

Springfield, IL 62706

(217) 785-6830

Department of Commerce and Community Affairs

Mitch Beaver, Deputy Director

Bureau of Energy and Recycling

322 West Adams Street \#360

Springfield, IL 62704

(217) 785-2800

Fax: (217) 785-2618

State Geologist

William W. Shilts

Illinois Geological Survey

121 Natural Resources Building

615 East Peabody Drive

Champaign, IL 61820

(217) 333-5111

Fax: (217) 244-7004

State Oil and Gas Agency

Lawrence E. Bengal, Division Supervisor Illinois Department of Natural Resources

Office of Mines and Minerals

Oil and Gas Division

524 South Second Street

Springfield, IL 62701-1787

(217) 782-1689

Fax: (217) 524-4819

Commerce Commission

Donna M. Caton, Chief Clerk

527 E. Capitol Avenue

Box 19280

Springfield, IL 62794-9280

(217) 782-7434

Fax: (217) 524-0673

$300 \quad$ Indiana

Governor Frank O'Bannon

206 State House

Indianapolis, IN 46204

(317) 232-4567

Fax: (317) 232-3443

Indiana Department of Commerce

Cheryl L. DeVol-Glowinski, Director

Energy Policy Division

One North Capitol, Suite 700

Indianapolis, IN 46204-2288

(317) $232-8939$

Fax: (317) 232-8995 
State Geologist

Norman C. Hester

Indiana Geological Survey

611 N. Walnut Grove

Bloomington, IN 47405

(812) 855-5067

Fax: (812) 855-2862

State Oil and Gas Agency

James A. Slutz, Director

Department of Natural Resources

Oil and Gas Division

402 W. Washington Street, Room 293

Indianapolis, IN 46204

(317) 232-4055

Fax: (317) 232-1550

Utility Regulatory Commission

302 West Washington Street

Suite E-306

Indianapolis, IN 46204

(317) 232-2716

Fax: (317) 232-6758

301

lowa

Governor Terry E. Branstad

State Capitol

Des Moines, IA 50319-0001

(515) 281-5211

State Energy Office

Larry Bean

lowa Department of Natural Resources

Energy and Geological Resources Division

Wallace State Office Building

Des Moines, IA 50319

(515) 281-6682

Fax: (515) 281-6794

State Geologist

Donald L. Koch, State Geologist

Geological Survey Bureau

109 Trowbridge Hall

lowa City, IA 52242-1319

(319) 335-1575

Fax: (319) 335-2754

lowa Utilities Board

Raymond K. Vawter, Executive Secretary

Lucas State Office Building

Des Moines, IA 50319

(515) 281-5256

\section{Kansas}

Governor Bill Graves

Capitol Building, Second Floor

Topeka, KS $66612-1590$

(913) 296-3232
State Energy Office

Jim Ploger, Energy Program Manager

Energy Programs

Kansas Corporation Commission

1500 S.W. Arrowhead Road

Topeka, KS 66604-4027

(913) 271-3349

Fax: (913) 271-3268

State Geologist

Lee C. Gerhard

Kansas Geological Survey

1930 Constant Avenue

West Campus

The University of Kansas

Lawrence, KS 66047

(913) 864-3965

Fax: (913) 864-5317

State Oil and Gas Agency

N. L. Korphage, Director

Kansas Corporation Commission

Conservation Division

130 South Market, Room 2078

Wichita, KS 67202-3802

(316) 337-6200

Fax: (316) 337-6211

Corporation Commission

Judith McConnell

Kansas Corporation Commission

1500 S.W. Arrowhead Road

Topeka, KS 66604

(913) 271-3169

Fax: (913) 271-3354

303 Kentucky

Governor Paul E. Patton

State Capitol

700 Capitol Avenue

Frankfort, KY 40601

(502) 564-2611

Fax: (502) 564-2517

State Energy Office

John M. Stapleton, Director

Kentucky Division of Energy

663 Teton Trail

Frankfort, KY 40601

(502) 564-7192

Fax: (502) 564-7484

State Geologist

Donald C. Haney

Kentucky Geological Survey

228 Mining and Mineral Resources Building

University of Kentucky

Lexington, KY 40506-0107

(606) 257-5500 
State Oil and Gas Agency

Rick Bender, Director

Department of Mines and Minerals

Division of Oil and Gas

Box 14090

Lexington, $\mathrm{KY} \quad 40512-4090$

(606) 246-2026

Fax: (606) 246-2038

Public Service Commission

Don Mills, Executive Director

730 Schenkel Lane, Box 615

Frankfort, KY 40602

(502) 564-3940

304 Louisiana

Governor M.S. "Mike" Foster, Jr.

State Capitol

P.O. Box 94004

Baton Rouge, LA 70804-9004

(504) 342-7015

Fax: (504) 342-7099

State Energy Office

Paula Ridgeway

Louisiana Department of Natural Resources

P.O. Box 44156

Baton Rouge, LA 70804-4156

(504) 342-1399

Fax: (504) 342-1397

State Geologist

William E. Marsalis

Louisiana Geological Survey

P.O. Box G

University Station

Baton Rouge, LA 70893

(504) 388-5320

Fax: (504) $388-5328$

State Oil and Gas Agency

George L. Carmouche, Commissioner

Office of Conservation

Box 94275

Baton Rouge, LA 70804-9275

(504) $342-5500$

Public Service Commission

Lawrence C. St. Blanc, Secretary

Suite 1630, One American Place

Baton Rouge, LA 70825

(504) $342-4427$

Mail letters to:

P.O. Box 91154

Baton Rouge, LA 70821-9154
Maine

Governor Angus S. King, Jr.

\#1 State House Station

Augusta, ME 04333-0001

(207) 287-3531

Fax: (207) 287-1034

\section{State Energy Office}

Brian K. Dancause, Supervisor

Energy Conservation Division

Department of Economic and Community

Development

59 State House Station

Augusta, ME 04333

(207) $287-2656$

Fax: (207) 287-5701

State Geologist

Robert G. Marvinney

Maine Geological Survey

Natural Resources Information and Mapping

Center

Department of Conservation

22 State House Station

Augusta, ME 04333-0022

(207) 287-2801

Fax: (207) 287-2353

Public Utilities Commission

Christoper P. Simpson, Administrative

Director

18 State House Station

242 State Street

Augusta, ME 04333

(207) 287-3831

Fax: (207) 287-1039

306 Maryland

Governor Parris N. Glendening State House, 100 State Circle

Annapolis, MD 21404

(410) 974-3901

Fax: $(410)$ 974-3275

State Energy Office

Frederic K. Hoover, Jr., Director

Maryland Energy Administration

45 Calvert Street, 4th Floor

Annapolis, MD 21401

(410) $974-2511$

Fax: (410) 974-2250 
State Geologist

Emery T. Cleaves

Maryland Geological Survey

2300 St. Paul Street

Baltimore, MD 21218-5210

(410) 554-5500

Fax: (410) 554-5502

E-Mail: ecleaves@mgs.dnr.md.gov

State Oil and Gas Regulations/Permitting Agency

Ed Larrimore

Minerals, Oil and Gas Division

Department of Environment

2500 Broening Highway

Baltimore, MD 21224

(410) 974-3874

Fax: (410) 974-5067

State Oil and Gas Resources Agency

(Advisory)

Kenneth A. Schwarz

Maryland Geological Survey

2300 St. Paul Street

Baltimore, MD 21218-5210

(410) 554-5525

Fax: (410) 554-5502

State Oil and Gas Resources Regulatory

Agency

Al Kampmeyer

Minerals, Oil and Gas Division

Maryland Department of Environment

Tawes State Office Building

580 Taylor Avenue

Annapolis, MD 21401

(410) $974-3874$

Fax: (410) 974-5067

Public Service Commission

Daniel P. Gahagan

6 St. Paul Centre

Baltimore, MD 21202-6806

(410) 767-8067

Massachusetts

Governor William F. Weld

State House, Room 360

Boston, MA 02133

(617) $727-9173$

\section{State Energy Office}

David L. O'Connor, Commissioner

Massachusetts Division of Energy Resources

Leverett Saltonstall Building

100 Cambridge Street, Room 1500

Boston, MA 02202

(617) 727-4732

Fax: $(617\rangle 727-0030$
E-Mail: energy@state.ma.us

URL: http://www.magnet.state.ma.us/doer

State Geologist

Richard N. Foster

Massachusetts Geological Survey

Commonwealth of Massachusetts

Executive Environmental Affairs

100 Cambridge Street, 20th Floor

Boston, MA 02202

(617) 727-5830, Ext. 305

Fax: $(617) 727-2754$

Department of Public Utilities

100 Cambridge Street, 12th Floor

Boston, MA 02202

(617) $727-3500$

\section{Michigan}

Governor John Engler

State Capitol

Lansing, MI 48909

(517) 373-3400

Public Service Commission

John Strand, Chairman

Michigan Public Service Commission

P.O. Box 30221

6545 Mercantile Way

Lansing, MI 48909

(517) 334-6370

Fax: $(517) 882-5002$

309 Minnesota

Governor Arne H. Carlson

130 State Capitol

75 Constitution Avenue

St. Paul, MN 55155

(612) 296-3391

State Energy Office

Krista L. Sanda, Commissioner

Department of Public Service

121 7th Place East, Suite 200

St. Paul, MN 55101-2145

(612) 296-7107

Fax: (617) 297-1959

State Geologist

David L. Southwick, Director

Minnesota Geological Survey

University of Minnesota

2642 University Avenue

St. Paul, MN 55114-1057

(612) $627-4780$

Fax: (612) 627-4778

E-Mail: mgs@gold.tc.umn.edu 
Public Utilities Commission Rick Lancaster, Executive Secretary 121 Seventh Place East, Suite 350 St. Paul, MN 55101-2147 (612) 296-7124

Mississippi

Governor Kirk Fordice State Capitol P.O. Box 139

Jackson, MS 39205

(601) $359-3150$

\section{State Energy Office}

Chester B. Smith, Director

Mississippi Department of Economic and Community Development

Energy Division

P.O. Box 850

Jackson, MS 39205-0850

(601) 359-6600

Fax: (601) 359-6642

\section{State Geologist}

S. Cragin Knox

Mississippi Office of Geology

Department of Environmental Quality

P.O. Box 20307

Jackson, MS 39289-1307

(601) 961-5500

State Oil and Gas Agency

W. R. Lewis, Supervisor

State Oil and Gas Board

500 Greymont, Suite E

Jackson, MS 39202

(601) 354-7142

Fax: (601) 354-6873

Mississippi Public Utilities Staff

Robert G. Waites, Director

Room 1738, Walter Sillers State Office

Building

P.O. Box 1174

Jackson, MS 39215-1174

(601) $961-5493$

\section{Missouri}

Governor Mel Carnahan

State Capitol, Room 216

Jefferson City, MO 65101

(573) $751-3222$
State Energy Office

Division of Energy

Missouri Department of Natural Resources

P.O. Box 176

Jefferson City, MO 65102

(573) 751-4000

Fax: (573) $751-6860$

State Geologist

James H. Williams

Missouri Geological Survey

Department of Natural Resources

Division of Geology and Land Survey

P.O. Box 250

Rolla, MO 65402

(573) 368-2165

Fax: (573) 368-2111

Public Service Commission

Cecil Wright

Executive Secretary

P.O. Box 360

Jefferson City, MO 65102

(573) 751-3234

\section{Montana}

Governor Marc Racicot

State Capitol

Helena, MT 59620-0801

(406) 444-3111

\section{State Energy Office}

Van Jamison, Administrator

Department of Environmental Quality

Planning, Prevention and Assistance Division

1520 East Sixth Avenue

Helena, MT 59620-0901

(406) 444-6812

Fax: (406) 444-1804

\section{State Geologist}

John C. Steinmetz

Montana Bureau of Mines and Geology

Montana Tech of the University of Montana

1300 West Park Street

Main Hall

Butte, MT 59701-8997

(406) $496-4180$

Fax: (406) 496-4451

Oil and Gas Agency

Thomas P. Richmond

Administrator-Petroleum Engineer

Board of Oil and Gas Conservation

2535 St. John's Avenue

Billings, MT 59102

(406) 656-0040 
Public Service Commission

Kathy Anderson, Commission Secretary

1701 Prospect Avenue

Helena, MT 59620

(406) 444-6170

Fax: (406) 444-7618

\section{Nebraska}

Governor E. Benjamin Nelson

State Capitol

P.O. Box 94848

Lincoln, NE 68509-4848

(402) 471-2244

Fax: (402) 471-6031

\section{State Energy Office}

Robert Harris, Director

Nebraska Energy Office

The Atrium, 1st Floor

1200 N Street, Suite 110

Lincoin, NE 68509

(402) 471-2867

Fax: (402) 471-3064

State Geologist

Perry B. Wigley

Nebraska Geological Survey

Conservation and Survey Division

Institute of Agriculture and Natural

Resources

University of Nebraska

113 Nebraska Hall

901 N. 17th Street

Lincoln, NE 68588-0517

(402) 472-3471

Fax: (402) 472-2410

State Oil and Gas Agency

William H. Sydow, Director

Oil and Gas Conservation Commission

Box 399

Sidney, NE 69162

(308) 254-6919

Fax: (308) 245-6922

Public Service Commission

M. G. Hand, Chief Engineer

300 The Atrium

1200 N Street, P. O. Box 94927

Lincoln, NE 68509-4927

(402) 471-3101

\section{Nevada}

Governor Bob Miller

State Capitol

Carson City, NV 89710

(702) $687-5670$
State Energy Office

DeeAnn Parsons, Chief

Nevada State Energy Office

1050 East William, Suite 435

Carson City, NV 89710

(702) $687-4910$

Fax: (702) 687-4914

State Geologist

Jonathan $G$. Price

Nevada Bureau of Mines and Geology

University of Nevada

Reno, NV 89557-0088

(702) 784-6691

Fax: (702) 784-1709

E-mail: jprice@nbmg.unr.edu

State Oil and Gas Agency

Russ Fields, Administrator

Department of Business and Industry

Division of Minerals

$400 \mathrm{~W}$. King Street, Suite 106

Carson City, NV 89710

(702) 687-5050

Fax: (702) 687-3957

Public Service Commission

William H. Vance, Secretary

727 Fairview Drive

Carson City, NV 89710

(702) 687-6007

Fax: (702) 687-6110

\section{New Hampshire}

Governor Jeanne Shaheen

State House, Room 208

Concord, NH 03301

(603) 271-2121

\section{State Energy Office}

Jonathan Osgood, Director

Office of Energy and Community Service

57 Regional Drive

Concord, NH 03301-8519

(603) 271-2711

Fax: (603) $271-2615$

State Geologist

Eugene L. Boudette

New Hampshire Geological Survey

Department of Environmental Services

P.O. Box 2008

Concord, NH 03302-2008

(603) 271-3406

Fax: (603) 271-7894

Public Utilities Commission

Sarah P. Voll, Secretary and Executive Director 
8 Old Suncook Road

Concord, NH 03301-7319

(603) 271-2431

Fax: (603) $271-3878$

New Jersey

Governor Christine T. Whitman

$125 \mathrm{~W}$. State Street, CN-001

Trenton, NJ 08625

(609) 292-6000

State Geologist

Haig F. Kasabach

New Jersey Geological Survey

Department of Environmental Protection

P.O. Box $\mathrm{CN}-427$

Trenton, NJ 08625

(609) 292-1185

Fax: (609) 633-1004

New Jersey Board of Public Utilities

Herbert Tate, President

2 Gateway Center, 8th Floor

Newark, NJ 07102

(201) 648-2503

Robert Chilton, Director

Division of Gas, Electric and Energy

2 Gateway Center, 9th Floor

Newark, NJ 07102

(201) 648-3621

Fax: (201) 648-2467

\section{New Mexico}

Governor Gary E. Johnson

State Capitol, Fourth Floor

Santa Fe, NM 87503

(505) $827-3000$

\section{State Energy Office}

Dianne Caron, Director

Energy Conservation \& Management Division

Energy, Minerals \& Natural Resources

Department

2040 South Pacheco

Santa Fe, NM 87505

(505) $827-5900$

Fax: (505) 428-3855

State Geologist

Charles E. Chapin

New Mexico Bureau of Mines Minerals

Resources

Campus Station

Socorro, NM 87801

(505) $835-5420$

Fax: (505) 835-6333
State Oil and Gas Agency

William J. LeMay, Director

Energy, Minerals and Natural Resources

Department

Oil and Conservation Division

Box 2040 S. Pacheco

Santa Fe, NM 87505

(505) $827-7131$

Fax: (505) 827-8177

Public Utility Commission

Dave Warren, Executive Director

224 E. Palace

Santa Fe, NM 87501-2013

(505) 827-6940

318 New York

Governor George E. Pataki

Executive Chamber

State Capitol

Albany, NY 12224

(518) 474-8390

State Geologist

Robert H. Fakundiny

New York Geological Survey

State Museum

Empire State Plaza

3136 Cultural Education Center

Albany, NY 12230

(518) 474-5816

Fax: $(518) 473-8496$

State Oil and Gas Agency

Gregory H. Sovas, Director

Department of Environmental Conservation

Division of Mineral Resources

50 Wolf Road, Room 290

Albany, NY 12233-6500

(518) 457-9337

Department of Service Commission John C. Crary, Secretary

3 Empire State Plaza

Albany, NY 12223-1350

(518) 474-6530

Fax: (518) 486-6081

E-Mail: web@dps.state.ny.us

\section{North Carolina}

Governor James B. Hunt, Jr.

State Capitol

$116 \mathrm{~W}$. Jones Street

Raleigh, NC 27603-8001

(919) $733-4240$ 
State Energy Office

Carson D. Culbreth, Director

North Carolina Department of Commerce

Energy Division

430 North Salisbury Street

P.O. Box 25249

Raleigh, NC 27611

(919) 733-1889

Fax: (919) 733-2953

State Geologist

Charles H. Gardner

North Carolina Geological Survey

Department of Environment, Health, and

Natural Resources

Division of Land Resources

P.O. Box 27687

Raleigh, NC 27611-7687

(919) 733-3833

Fax: (919) 733-4407, (919) 733-2876

Public Utilities Commission

Robert P. Gruber, Executive Director

Public Staff, P.O. Box 29520

Raleigh, NC 27626-0520

(919) 733-2435

\section{North Dakota}

Governor Edward T. Schafer

State Capitol

600 E. Boulevard Avenue

Bismarck, ND 58505-0001

(701) 328-2200

\section{State Energy Office}

Kim Christianson

Energy Program Manager

Office of Intergovernmental Assistance

State Capitol Building

600 E. Boulevard Avenue, 14th Floor

Bismarck, ND 58505-0170

(701) 328-2094

Fax: (701) 328-2308

State Geologist

John P. Bluemle, State Geologist

North Dakota Geological Survey

600 East Boulevard Avenue

Bismarck, ND 58505-0840

(701) 328-9700

Fax: (701) 328-9898

State Oil and Gas Agency

Wesley D. Norton, Director

Industrial Commission

Oil and Gas Division

600 East Boulevard Avenue

Bismarck, ND 58505-0840

(701) 328-9900
Fax: (701) 328-9898

Public Service Commission

Jon H. Mielke, Executive Secretary

State Capitol

Bismarck, ND 58505

(701) $328-2400$

321 Ohio

Governor George Voinovich

77 South High Street

30th Floor

Columbus, $\mathrm{OH}$ 43266-0601

(614) 466-3555

State Energy Office

Donald Jakeway, Director

Ohio Department of Development

Community Development Division

Office of Energy Efficiency

$77 \mathrm{~S}$. High Street, 26th Floor

Columbus, $\mathrm{OH} 43266-0413$

(614) 466-6797

State Geologist

Thomas M. Berg

Division of Geological Survey

Ohio Department of Natural Resources

4383 Fountain Square Drive, Building B

Columbus, $\mathrm{OH} 43224$

(614) 265-6576

Fax: $(614) 447-1918$

State Oil and Gas Agency

Donald L. Mason, Esq., Chief

Department of Natural Resources

Division of Oil and Gas

Fountain Square B-3

Columbus, $\mathrm{OH} 43224$

(614) 265-6922

Fax: (614) 268-4316

Public Utilities Commission

Gary Vigorito, Director

Administration and Commission Secretary

180 E. Broad Street

Columbus, $\mathrm{OH}$ 43266-0573

(614) $466-4294$

322 Oklahoma

Governor Frank Keating

State Capitol Building

Suite 212

Oklahoma City, OK 73105

(405) 521-2342

Fax: (405) 522-3492 
Secretary of Energy

Honorable Charles Nesbitt

125 N.W. Sixth Street

Oklahoma City, OK 73105

(405) 235-4204

State Alternative Fuels Office

Jeanie Robards, Administrator

Alternative Fuels Program

Department of Central Services

3301 North Santa Fe

Oklahoma City, OK 73118

(405) 521-4687

Fax: (405) 525-2682

State Energy Office

Sherwood Washington

Oklahoma Department of Commerce

Division of Community Affairs and

Development

P.O. Box 26980

Oklahoma City, OK 73126-0980

(405) 841-9326

Fax: (405) 841-9344

State Geologist

Charles J. Mankin

Oklahoma Geological Survey

100 East Boyd, Room N-131

Norman, OK 73019-0628

(405) 325-3031

Fax: (405) 325-7069

State Oil and Gas Agency

Charles D. Davidson, Director

Oil and Gas Conservation Division

Corporation Commission

Jim Thorpe Building

Oklahoma City, OK 73105

(405) 521-2303

Oklahoma Corporation Commission

Ernest G. Johnson, Director

Public Utility Division

$500 \mathrm{Jim}$ Thorpe Office Building

2101 North Lincoln Boulevard

Oklahoma City, OK 73105

(405) 521-3908

Larry A. Schroeder, Deputy Director (405) $521-2518$

\section{Oregon}

Governor John Kitzhaber

254 State Capitol

Salem, OR 97310

(503) 378-3100

Fax: (503) 378-3225
State Energy Office

John Savage, Director

Oregon Department of Energy

625 Marion Street NE

Salem, OR 97310-0831

(503) $378-4040$

Fax: (503) 373-7806

State Geologist and Director

Donald A. Hull

Oregon Department of Geology and Mineral Industries

800 NE Oregon Street, \#28, Room 965

Portland, OR 97232

(503) 731-4100

Fax: (503) 731-4066

Public Utility Commission

Ron Eachus, Commissioner

550 Capitol Street, N.E.

Salem, OR 97310-1380

(503) 378-6611

324 Pennsylvania

Governor Tom Ridge

225 Mail Capitol Building

Harrisburg, PA 17120

(717) 787-2500

State Geologist

Donald M. Hoskins

Pennsylvania Geological Survey

Bureau of Topographic and Geologic Survey

Department of Environmental Resources

P.O. Box 8453

Harrisburg, PA 17105-8453

(717) 787-2169

Fax: (717) 783-7267

State Oil and Gas Agency

James E. Erb, Director

Department of Environmental Protection

Bureau of Oil and Gas Management

Box 8765

Harrisburg, PA 17105-8765

(717) 772-2199

Public Utility Commission

John L. Dial, Executive Director

P.O. Box 3265

Harrisburg, PA 17120

(717) 783-1740

Fax: (717) 787-3417 
Puerto Rico

Governor Pedro J. Rossello

La Fortaleza

P.O. Box 902-0082

San Juan, PR 00902-0082

(787) 721-7000

Fax: (787) 725-1003

\section{State Energy Office}

Rafael Llompart, Administrator

Energy Affairs Administration

Department of Natural and Environmental

Resources

Puerto de Tierra

P.O. Box 5887

San Juan, PR 00906-5887

(787) 723-3636

Fax: (787) 721-3084

326 Rhode Island

Governor Lincoln Almond

State House

Providence, RI 02903

(401) 277-2080

Fax: (401) 521-7534

\section{State Energy Office}

Joseph V. Pomposelli, Director

Rhode Island State Energy Office

275 Westminister Street

Providence, RI 02903-5872

(401) 277-3370

Fax: (401) 277-1260

Public Utility Commission

100 Orange Street

Providence, RI 02903

(401) 277-3500

Fax: (401) 277-6805

\section{South Carolina}

Governor David M. Beasley

P.O. Box 11369

Columbia, SC 29211

(803) 734-9818

Fax: (803) 734-1598

State Energy Office

Jay Flanagan

1201 Main Street, Suite 820

Columbia, SC 29201

(803) $737-8030$

Fax: (803) 737-9846
State Geologist

William C. Clendenin, Jr.

South Carolina Geological Survey

5 Geology Road

Columbia, SC 29210-4089

(803) 896-7708

Fax: (803) 896-7695

Public Service Commission

D. Wayne Burdett, Manager

Utilities Department

P.O. Box 11649

Columbia, SC 29211

(803) 737-5125

Fax: (803) 737-5199

South Dakota

Governor William J. Janklow

500 E. Capitol

Pierre, SD 57501

(605) 773-3212

State Energy Program

Bonnie Unteneiner, Commissioner

Governor's Office of Economic Development

711 East Wells Avenue

Pierre, SD 57501-3369

(605) 773-5032

Fax: (605) 773-3256

State Geologist

Cleo Christensen

South Dakota Geological Survey

Department of Environment and Natural

Resources

University of South Dakota Science Center 414 Clark Street

Vermillion, SD 57069-2390

(605) 677-5227

Fax: (605) 677-5895

State Oil and Gas Agency

Nettie H. Myers, Secretary

Department of Environment and Natural

Resources

523 E. Capitol

Pierre, SD 57501

(605) 773-5559

Fax: (605) 773-6035

Public Utilities Commission

William Bullard, Jr., Executive Director

500 East Capitol

Pierre, SD 57501

(605) 773-3201 
Governor Dan Sundquist

State Capitol

Nashville, TN 37243-0001

(615) $741-2001$

\section{State Energy Office}

Cynthia Oliphant, Director

Tennessee Department of Economic and

Community Development

Energy Division

320 6th Avenue North, 6th Floor

Nashville, TN 37243-0405

(615) 741-2994

Fax: (615) 741-5070

\section{State Geologist}

Ronald P. Zurawski

Tennessee Geological Survey

Department of Environment and

Conservation

Division of Geology

L\&C Tower, 13th Floor

401 Church Street

Nashville, TN 37243-0445

(615) $532-1500$

Fax: (615) 532-0231

State Oil and Gas Agency

Michael K. Burton, Geologist 3

State Oil and Gas Board

Division of Water Supply

L\&C Tower, 6th Floor

401 Church Street

Nashville, TN 37243-0445

(615) 532-0162

Tennessee Regulatory Authority

Lynn Greer, Chairman

460 James Robertson Parkway

Nashville, TN 37243-0505

(615) 741-0917

Texas

Governor George W. Bush

P.O. Box 12428

Austin, TX 78711

(512) 463-2000

Texas Department of Housing and Community Affairs

J. A. Almguer

Energy Assistance Section

P.O. Box 13941

Austin, TX 78701

(512) $475-3800$

Fax: (512) 475-3935

\section{State Geologist}

Noel Tyler

Texas Geological Survey

Bureau of Economic Geology

The University of Texas at Austin

Box $X$, University Station

Austin, TX 78713-7508

(512) $471-7721$

Fax: (512) 471-0140

State Oil and Gas Agency

David E. Schieck, Director

Oil and Gas Division

Railroad Commission of Texas

Box 12967

Austin, TX 78711-2967

(512) 463-6893

Public Utility Commission of Texas

Public Information Office

P.O. Box 13326

Austin, TX 78711-3326

(512) $936-7140$

Utah

Governor Michael O. Leavitt

210 State Capitol Building

Salt Lake City, UT 84114

(801) 538-1000

Fax: (801) 538-1557

Office of Energy Services

Richard J. Bradford, Director

Division of Community Development

324 South State Street, Suite 320

Salt Lake City, UT 84111

(801) 538-8722

Fax: 1801$) 538-8888$

State Geologist

M. Lee Allison

Utah Geological Survey

1594 West North Temple, Suite 3110

P.O. Box 146100

Salt Lake City, UT $84114-6100$

(801) 537-3300

FAX: (801) $537-3400$

State Oil and Gas Agency

James W. Carter, Director

Division of Oil, Gas and Mining

1594 West North Temple, Suite 1210

Box 145801

Salt Lake City, UT 84114-5801

(801) 538-5327

Fax: (801) 538-5340 
Public Service Commission

Julie Orchard, Commission Secretary

160 East 300 South

Salt Lake City, UT 84111

(801) 530-6716

Fax: (801) 530-6796

\section{2}

\section{Vermont}

Governor Howard Dean

Pavillion Office Building

109 State Street

Montpelier, VT 05609

(802) 828-3333

Public Service Board

Susan M. Hudson, Clerk

112 State Street

Chittenden Bank Building, 4th Floor

Drawer 20

Montpelier, VT 05620-2701

(802) 828-2358

State Geologist

Laurence R. Becker

Agency of Natural Resources

Vermont Geological Survey

103 South Main Street, Center Building

Waterbury, VT 05671-0301

(802) 241-3608

Fax: (802) 244-1102

Department of Public Services

Scudder Parker, Director

Energy Efficiency Division

112 State Street, Drawer 20

Montpelier, VT 05620-2601

(802) 828-4009

Fax: (802) 828-2342

\section{Virginia}

Governor George F. Allen

State Capitol

P.O. Box 1477

Richmond, VA 23219

(804) $786-2211$

State Energy Office

O. Gene Dishner, Director

Division of Energy

Department of Mines, Minerals and Energy

202 N. Ninth Street, 8th Floor

Richmond, VA 23219

(804) 692-3200

Fax: (802) 692-3237
State Geologist

Stanley S. Johnson

Virginia Geological Survey

DMME, Division of Mineral Resources

Natural Resources Building

McCormick Road, P.O. Box 3667

Charlottesville, VA 22903

(804) 293-5121

Fax: (804) 293-2239

State Oil and Gas Agency

Byron T. Fulmer, Director

Division of Gas \& Oil

Department of Mines, Minerals and Energy

230 Charwood Drive

Abingdon, VA 24210

(540) 676-5423

Fax: (540) 676-5459

Mailing Address: P.O. Box 1416

Abigdon, VA 24212

State Corporation Commission

William J. Bridge, Clerk of the Commission

Tyler Building, 1300 E. Main Street

P.O. Box 1197

Richmond, VA 23218-1197

(804) 371-9733

Virgin Islands

Governor Roy Lester Schneider Office of the Governor

Governor's House

Charlotte Amalie

St. Thomas, VI 00802

(809) 774-0001

Fax: (809) 774-4988

\section{Energy Office}

Alicia Barnes James, Director

Virgin Islands Energy Office

Old Customs House

200 Strand Street

St. Croix, VI 00840

(809) $772-2616$

Fax: (809) 772-0063

\section{5}

\section{Washington}

Governor Mike Gary Locke

State Capitol

Legislative Building

Olympia, WA 98504-0002

(360) 753-6780 
State Energy Office

Kristine Growdon, Unit Manager

Washington State Energy Office

Cooperative Extension, Energy Programs

925 Plum Street, SE

P.O. Box 43165

Olympia, WA 98504-3165

(360) $956-2000$

Fax: (360) 956-2217

State Oil and Gas Agency

Raymond Lasmanis

Department of Natural Resources

Division of Geology and Earth Resources

P.O.Box 47007

Olympia, WA 98504-7007

(360) 902-1450

Fax: (360) 902-1785

Utilities and Transportation Commission

Mary Lu White, Librarian

WUTC Library Services

P.O. Box 47250

Olympia, WA $98504-7250$

(360) 586-0090

Fax: (360) 586-1145

\section{West Virginia}

Governor Cecil Underwood

State Capitol Complex

Charleston, WV 25305-0370

(304) 558-2000

Fax: (304) $342-7025$

State Energy Office

John F. (Jeff) Herholdt, Jr.

West Virginia Development Office

Energy Efficiency Program

Building 6, 645 Capital Complex

Charleston, WV 25305

(304) 558-0350

Fax: (304) 558-0362

\section{State Geologist}

Larry D. Woodfork

West Virginia Geological Survey

Mont Chateau Research Center

P.O. Box 879

Morgantown, WV 26507-0879

(304) 594-2331

Fax: (304) 594-2575

E-Mail: woodfork@wvsrv.wvnet.edu
State Oil and Gas Conservation Commission Thomas M. Streit, Acting Commissioner Oil and Gas Conservation Commission 10 McJunkin Road

Nitro, WV 25143-2506

(304) 759-0516

Fax: (304) 759-0529

Public Service Commission

Pamela J. Hicks

201 Brooks Street

P.O. Box 812

Charleston, WV 25323

(304) 340-0426

Wisconsin

Governor Tommy G. Thompson

State Capitol

P.O. Box 7863

Madison, WI 53707

(608) 266-1212

Fax: (608) 267-8983

State Energy Office

Nathaniel E. Robinson, Administrator

Wisconsin Division of Energy and Intergovernmental Relations 101 East Wilson Street, 6th Floor P.O. Box 7868

Madison, WI 53707-7868

(608) 266-8234

Fax: (608) 267-6931

\section{State Geologist}

James M. Robertson

Wisconsin Geological Survey

3817 Mineral Point Road

Madison, WI 53705-5100

(608) 262-1705

Fax: (608) 262-8086

Public Service Commission

Jeffrey L. Butson

Public Affairs Director

610 North Whitney Way

Madison, WI 53707

(608) 267-0912

Fax: (608) 266-1401

Mail letters to: P.O. Box 7854

Madison, WI 53707

338 Wyoming

Governor Jim Gerliner

State Capitol Building, Room 124

Cheyenne, WY 82002

(307) $777-7434$ 


\section{State Energy Office}

John F. Nunley, III, Federal Grants

Supervisor

Wyoming Department of Commerce

Division of Economic and Community

Development

6101 Yellowstone Road, 4th Floor North

Cheyenne, WY 82002

(307) 777-6420

Fax: (307) $777-5840$

State Geologist

Gary B. Glass

Geological Survey of Wyoming

Box 3008

University Station

Laramie, WY 82071-3008

(307) 766-2286

Fax: (307) 766-2605

Wyoming Oil and Gas Conservation

Commission

Donald B. Basko, Oil and Gas Supervisor

Box 2640

Casper, WY 82602

(307) 234-7147

Fax: (307) 234-5306

Public Service Commission

700 W. 21 st Street

Cheyenne, WY 82002

(307) 777-7427

Fax: (307) 777-5700 


\section{Trade Associations}

339 Air Conditioning Contractors of America 1712 New Hampshire Avenue, N.W. Washington, DC 20009

(202) $483-9370$

Heating and ventilation contractors who need technical information on energy conservation, building load calculations, or heat pump applications can contact this organization. A catalogue listing technical publications and business management aids is available. A free newsletter, "Air Conditioning Contractors of America News," is published monthly for members only.

Air Transport Association of America (ATA) Carol B. Halett, President

1301 Pennsylvania Avenue, N.W.

Suite 1100

Washington, DC 20006-1707

(202) $626-4000$

Responsible for airlines engaged in transporting persons, goods, and mail by aircraft between fixed terminals on regular schedules. Maintains resource library of transportation texts and congressional, administrative, and legal histories of civil aviation.

\section{Aircraft Owners and Pilots Association (AOPA) \\ Phil Boyer, President \\ 421 Aviation Way \\ Frederick, MD 21701 \\ (301) 695-2000 \\ Fax: (301) 695-2375}

A membership association representing 340,000 pilots and aircraft owners using general aviation aircraft for business and personal transportation. AOPA works closely with the Federal Aviation Administration, Department of Transportation, National Transportation Safety Board, the United States Congress, and with other aviation organizations to ensure that the interests of members and the entire general aviation community are represented at the Federal, State and local levels. The affiliated AOPA Air Safety Foundation conducts research, safety and educational programs and flight training clinics.

\section{Air Diffusion Council \\ 11 S. La Salle Street, Suite 1400 \\ Chicago, IL 60603-1210 \\ (312) 616-0800}

Administers industry-wide testing and rating standards, encourages basic research into the behavior of air currents in enclosed areas, and participates in activities related to flexible air ducts standards.

\section{American Architectural Manufacturers Association (AAMA) \\ 1827 Walden Office Square \\ Schaumburg, IL 60173-4268 \\ (847) 303-5664 \\ Fax: $(847) 303-5774$}

Dispenses technical information on architectural aluminum, storm windows, skylights, and window films. Provides technical information on coatings and finishes, weatherstrips, adhesives, and sealants, and sponsors product research and laboratory performance testing and a certification program for prime windows, storm windows and doors, and sliding glass doors.

\section{American Boiler Manufacturers Association} (ABMA)

R. N. Mosher, Executive Director

950 North Glebe Rd., Suite 160

Arlington, VA 22203

(703) $522-7350$

Fax: (703) 522-2665

ABMA members are manufacturers of utility, industrial, and commercial boilers, pressure vessels, and major components of the steam generating system. ABMA members are classified as either "active" or "associate." An active member is any person or organization that manufactures boiler systems or components for sale. An associate member is any person or organization that does work related to production, inspection, boiler insurance or boiler product technology. Associate members may also manufacture certain auxiliary apparatus.

\section{American Coal Ash Association (ACAA)}

Samuel S. Tyson, Executive Director

2760 Eisenhower Avenue

Suite 304

Alexandria, VA 22314

(703) 317-2400

Fax: (703) 317-2409

Members represent electric utility companies and systems, coal, and transportation companies; engineering, research, and development organizations; and ash marketing companies. Purposes are to provide technical assistance and information to coal ash producers, transporters, marketers, consumers, and other groups; to stimulate research and employment of ash uses, transport, and disposal; and to promote utilization of ash through 
advertising and public relations programs, dissemination of information on ash production, transport, storage, utilization, and research. ACAA works with a wide variety of end-user industries and with Federal and state government agencies, to develop materials specifications and guidelines for use of coal combustion by-products and, more recently, for clean coal technology by-products as well. Maintains a 500-item library, including manuals and technical papers.

\section{American Coal Foundation (ACF) \\ Beatrice Burns, Executive Director \\ 113017 th Street, N.W., Suite 220 \\ Washington, DC 20036 \\ (202) 466-8630}

Provides publications for grades $\mathrm{K}-12$, some of which are available in classroom sets; a film guide; activities and science fair ideas. Also available free of charge is a coal sample kit that contains samples of peat, lignite, bituminous coal, and anthracite, along with a brief description of the formation and different types of coal. Now available for purchase or free loan (grades 7-12 and adult groups) is a slide presentation "Understanding the Greenhouse Effect and Global Climate Change." The complete kit contains 53 numbered slides, a script, teacher's guide, brochure and $a$ one-page summary.

\section{American College of Nuclear Physicians (ACNP) \\ Karen Kimball, Executive Director \\ 1200 19th Street, N.W. \\ Suite 700 \\ Washington, DC 20036 \\ (202) 857-1135 \\ Fax: (202) 223-4579 \\ E-Mail: Karen_Kimball@sba.com}

Composed of 1,200 physicians and scientists dedicated to the advancement of the science of nuclear medicine through study, education, and improvement of the socioeconomic aspects of the practice. ACNP also conducts a professional and public information program to educate the media and public about biological radiation, and low-level radioactive waste management issues and the clinical and fiscal attributes of nuclear medicine. ACNP also administers several Quality Assurance and Practice Accreditation programs to ensure the highest quality in nuclear medicine service.

348 American Consulting Engineers Council (ACEC)

101515 th Street, N.W., Suite 802

Washington, DC 20005

(202) 347-7474

Fax: (202) 898-0068
Provides energy management services to commercial building owners. ACEC, a federation of state and local associations, provides referrals to engineering firms, and distributes publications on general energy information for commercial buildings.

\section{American Council on Education}

Sheldon Steinbach, Vice President and General Counsel

1 Dupont Circle, N.W., Suite 835

Washington, DC 20036

(202) 939-9355

Provides information on pending energy legislation affecting colleges and universities. Provides information on ongoing energy education programs and examples of renewable energy and conservation projects undertaken by colleges and universities. All members of the academic community are invited to use the services of this organization.

\section{American Gas Association (AGA) \\ Michael Baly III, President and CEO 1515 Wilson Boulevard \\ Arlington, VA 22209 \\ (703) $841-8400$}

Provides information on sales, finance, utilization, research, management, safety, accounting, and all phases of gas transmission and distribution. Sponsors competitions among primary and secondary students and public service and informational advertising. Promotes employee and public safety. Compiles a wide variety of national and regional statistical, economic, financial, and marketing studies; develops operating practices and gas rate schedules for every type of service for virtually all gas companies. Maintains an independent committee which compiles standards on construction and performance of appliances and equipment, as well as special committees in areas of industry interest.

\section{American Iron and Steel Institute (AISI) \\ Andrew G. Sharkey, President \\ 1101 17th Street, N.W., Suite 1300 \\ Washington, DC 20036 \\ (202) $452-7100$}

Members include basic manufacturers in the steel industry, Members operate steel mills, blast furnaces, finishing mills, and iron ore mines. Products include pig iron, steel ingots, sheets, plates, bars, shapes, strips, tin plate, nails, pipe and tubes, railroad rails, wire products, and other basic forms of ferrous metals. Conducts extensive research programs on manufacturing technology, basic materials, environmental quality control, energy and fuels consumption. 
352 American Lighting Association (ALA)

World Trade Center, Suite 10046

P.O. Box 420288

2050 Stemmons Freeway

Dallas, TX 75342-0288

(214) 698-9898

Fax: (214) 698-9899

Provides general and technical information on the efficient use of lighting. The ALA (formerly the American Home Lighting Institute) is composed of manufacturers and their marketing representatives and showroom distributors. ALA also provides requestors with referrals to showroom distributors of energy-efficient lighting products in their area. Call 1-800-BRIGHT IDEAS.

\section{American Nuclear Energy Council (ANEC) \\ Edward M. Davis, President \\ 410 First Street, S.E. \\ Washington, DC 20003 \\ (202) 484-2670}

Organizations having an interest in any facet of the peaceful application of nuclear energy, including uranium suppliers, utilities, engineers/contractors, and equipment manufacturers. Purposes are to support development of nuclear power as an energy source; to coordinate and project the interests of the American nuclear industry to Congress and the Executive Branch; to relate Congressional and Executive Branch actions affecting nuclear energy issues to member companies.

\section{American Petroleum Institute (API)}

Charles J. DiBona, President

1220 L Street, N.W.

Washington, DC 20005

Publications Department: (202) 682-8375

Library: (202) 682-8042

The American Petroleum Institute is a trade association that represents the domestic petroleum industry. For a list of current publications, call the Publications Department. For out-of-print API publications, contact the Library.

355

\author{
American Public Power Association (APPA) \\ Alan H. Richardson, Executive Director \\ 2301 M Street, N.W. \\ Washington, DC 20037-1484 \\ (202) 467-2900 \\ Fax: (202) 467-2910
}

APPA represents the nation's 2,000 not-for-profit, community and state-owned electric utilities that serve 35 million Americans. APPA offers services in the areas of government relations, engineering and operations, accounting and finance, energy services, customer services, public communications, economics and statistics, legal issues, and management and policy making. It holds an annual conference in June as well as many workshops and seminars.

356 American Society for Testing and Materials (ASTM)

James A. Thomas, President

100 Barr Harbor Drive

West Conshohocken, PA 19428

(610) 832-9500

ASTM members include engineers, scientists, managers, professionals, academicians, consumers, and skilled technicians who also hold membership as individuals in or as representatives of business firms, government agencies, educational institutions, and laboratories. Establishes voluntary standards for materials, products, systems, and services. Has 130 technical committees (each having five to 50 subcommittees). New committees are organized each year to keep pace with technological advances. Sponsors more than 40 symposiums each year. Has developed more than 9,000 standard test methods, specifications, classifications, definitions, and recommended practices now in use.

357 American Society of Agricultural Engineers 2950 Niles Road

St. Joseph, MI 49085

(616) 429-0300

Responds to technical inquiries on biomass, alcohol fuels, vegetable oil fuels, solar energy, and wind energy. Publishes technical papers, books, conference proceedings, exports' anthologies on various subjects, and a bimonthly magazine entitled "Agricultural Engineering." A listing of publications and prices is available upon request.

\section{American Underground Space Association}

51111 th Avenue, South

Box 320

Minneapolis, MN 55415

(615) 339-5403

As a multi-disciplinary, nonprofit, professional organization involved in developing and using underground space, provides information and educational materials on underground space to its members and the general public. Provides a forum where technical, economic, social, environmental, and policy-related issues about developing and using underground space are discussed. 
American Wind Energy Association (AWEA)

122 C Street, N.W., 4th Floor

Washington, DC 20001

(202) 383-2520

Fax: (202) 383-2505

E-Mail: windmail@mcimail.com

URL: http://www.igc.apc.org/awea/

AWEA is the national trade organization representing the wind energy industry. The Association works to further the development of wind energy as a clean, reliable energy alternative at the federal and state levels, with emphasis on legislative and regulatory issues.

Disseminates information concerning wind technology and industry activities to the news media, the general public, and to key target audiences such as electric utilities and state regulators. In addition, AWEA participates in export development in cooperation with U.S. federal agencies to promote wind energy as a key to sustainable development.

360 APA - The Engineered Wood Association

7011 S. 19th Street

P.O. Box 11700

Tacoma, WA 98411

(206) 565-6600

Provides information on the various aspects of structural wood panels. Builders and contractors may call with questions on energy conservation and the insulating properties of wood. The Association, representing 50 member companies in both the United States and Canada, is involved in quality testing and inspection, research and development, and product promotion.

\section{Association of American Railroads (AAR)}

Edwin L. Harper, President \& CEO

American Railroads Building

50 F Street, N.W.

Washington, DC 20001

(202) $639-2100$

Represents railroads operating in North America. Conducts research and collects information in the following areas: alternative locomotive fuels; fuel security and management; the reduction of fuel consumption through engine modification, rail lubrication, and changes in railroad operations; and alternatives to diesel engines.

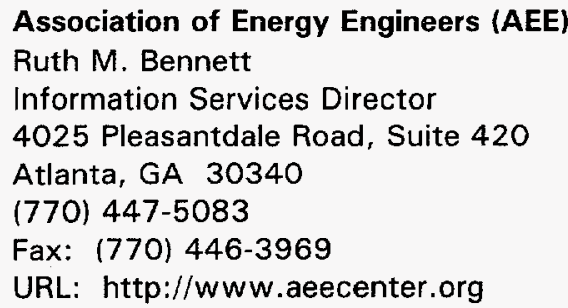

AEE members include engineers, architects, and other professionals with an interest in energy management and cogeneration, manufacturers and industries involved in energy and the environment. Promotes the advancement of the profession and contributes to the professional development of members. Conducts seminars and conferences. Sponsors the Cogeneration and Competitive Power Institute, the Environmental Engineers and Managers Institute, and the Energy Services Marketing Society.

\section{3}

\author{
Association of Home Appliance \\ Manufacturers \\ 20 North Wacker Drive \\ Chicago, IL 60606 \\ (312) 984-5800 \\ Fax On Demand: (312) 984-9950
}

Supplies information on the energy efficiency of major appliances. A publications list is available upon request. You must call from a fax machine handset to receive information from Fax On Demand system.

\section{Association of Pellet Fuel Industries 555116 th N.E., Suite 250 \\ Bellevue, WA 98004 \\ (206) 453-8422}

Offers a directory of pellet appliance manufacturers and their products. Also provides an information referral service for retailers and manufacturers.

\section{Biomass Energy Research Association (BERA) \\ Donald L. Klass, President \\ 3540 South George Mason Drive \\ Alexandria, VA 22302-1034 \\ (800) 247-1755 \\ Fax: (847) 382-5595}

BERA is a nonprofit membership association founded in 1982 by industry and university researchers throughout North America who are interested in the development and commercial utilization of renewable, environmentally clean biomass energy systems. BERA's mission is to promote research in both the public and private sectors and to facilitate technology transfer from the laboratory to industry, information exchange, education, and international cooperation on biomass energy. Publishes an annual 
position statement on the Federal funding of biofuels research, demonstration, and technology transfer to the private sector; testifies before Congressional committees on Federal biomass energy programs; hosts bimonthly "Capitol Hill Luncheons" in Washington, DC, to improve communications and program coordination and to educate policy makers on the potential of biomass energy; operates a Consultants' Clearinghouse and a Speakers' Bureau for members; provides an award of $\$ 1,000$, a plaque, and a certificate to recognize outstanding biomass energy research or commercialization; responds to inquiries from the public and private sectors on biomass energy; provides objective evaluations of selected proposals and research reports; participates in national and international meetings and conferences on biomass energy; and maintains affiliation with the journal Bioresources Technology. Recently, BERA published a vendors' catalog of renewable energy hardware and systems for the purpose of promoting U.S. exports.

\section{Brick Institute of America \\ 11490 Commerce Park Drive \\ Reston, VA 20191-1525 \\ (703) 620-0010 \\ Fax: (703) 620-3928}

Offers information on the thermal properties of brick and its use in passive solar applications, as well as other aspects of brick design.

\section{Ceilings and Interior Systems Construction Association 1500 Lincoln Highway, Suite 202 \\ St. Charles, IL 60174 \\ (630) $584-1919$}

Answers inquiries on interior insulation systems, interior lighting, air control, sound absorption, acoustics, and access floors. Offers information regarding recommendations on seismic, glass reinforced gypsum, and access floors.

\section{Consumer Energy Council of America Research Foundation (CECA/RF) Ellen Berman, Executive Director 2000 L Street, N.W. \\ Suite 802 \\ Washington, DC 20036 \\ (202) 659-0404}

Founded in 1973, CECA/RF is the nation's oldest public interest energy policy organization. Provides a leading national resource pool of information, analysis, and expertise on a wide variety of energy initiatives; conducts in-depth analyses on economic and social impacts of energy policies; develops long-range conservation and loan management strategies for utility companies; designs pilot projects and conducts research on conservation initiatives for government agencies and private research foundations. Has a primary commitment to ensuring reliable and affordable energy for all sectors of our Nation and, as such, places a strong emphasis on conservation and energy efficiency programs as the cornerstone of a sound energy economy. Provides a forum for consensus among public and private sector organizations, State and local groups, businesses, utilities, consumers, environmentalists, government agencies, and others to further consumer interests. Is currently studying public policy issues relating to the environmental externalities of energy production, transmission siting and certification issues, and air pollution emissions trading under the Clean Air Act Amendments of 1990. Maintains a library and information on $\$ 4$ billion oil overcharge funds and a data base on utility appliance rebate programs.

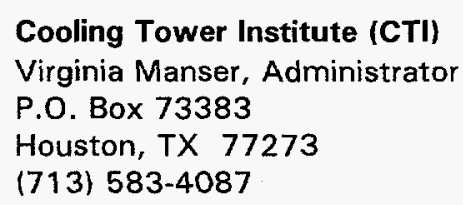

Goals are to improve technology, design, and performance of water conservation apparatus. Has developed standard specifications for cooling towers; provides inspection services. Conducts research through technical subcommittees. Sponsors workshops, seminars, and projects.

\section{0}

\author{
Council of Industrial Boiler Owners (CIBO) \\ Robert D. Bessette, President \\ 6035 Burke Centre Parkway, Suite 360 \\ Burke, VA 22015 \\ (703) 250-9042 \\ Fax: (703) 239-9042
}

CIBO is a broad-based association of industrial boiler owners, architect-engineers, related equipment manufacturers, and university affiliates consisting of over 100 members representing 20 major industrial sectors. CIBO was formed in 1978 to promote the exchange of information between industry and government relating to energy and environmental policies, laws and regulations affecting industrial boilers. Since it formation, CIBO has taken an active interest in the development of technically sound, reasonable, cost-effective regulations for industrial boilers.

\author{
371 Direct Current Electricity Institute (DCEI) \\ Michael Kilgore, Interim President \\ 7411 Alban Station Court, Suite B265 \\ Springfield, VA 22150 \\ (800) 470-3823 \\ Fax: (703) 569-3468 \\ E-Mail: INDRESINC@AOL.COM
}


A research center for the analysis of the consumption of Direct Current Electricity (DC) and impact that it has on the energy production of the U.S. and the world. Consists of representatives of the users and manufacturers of DC powered equipment for appliances (battery/transformer), commercial machines, communication systems (line/mobile/satellite), computers, control systems, transportation systems (rail/transit/automotive), uninterruptible power supply systems and photovoltaics. Educational programs, seminars and a speakers bureau are provided.

\section{Edison Electric Institute (EEI)}

Lynn LeMaster, Senior Vice President Issue Management and Administration 701 Pennsylvania Avenue, N.W. Washington, DC 20004-2696 (202) 508-5475

Represents investor-owned electric utility companies operating in the United States. Has affiliated members worldwide.

\section{Electrical Generating Systems Association (EGSA) \\ David L. Kellough, Executive Director \\ 10251 W. Sample Road \#B \\ Coral Springs, FL 33065-3939 \\ (954) 755-2677 \\ Fax: (954) 755-2679}

Members include manufacturers of devices used to generate electrical power through the use of an internal combustion engine or a gas turbine coupled to a generator; their suppliers and distributors. Conducts basic and advanced training programs. Compiles statistics.

\section{Electric Generation Association}

Margaret A. Welsh, Executive Director

1401 H Street, N.W., Suite 760

Washington, DC 20005

(202) 789-7200

Represents independent power producers and suppliers of goods and services to the competitive wholesale electric industry.

\section{Electricity Consumers Resource Council (ELCON) \\ John A. Anderson, Executive Director \\ 1333 H Street, N.W. \\ West Tower, 8th Floor \\ Washington, DC 20006 \\ (202) 682-1390}

Represents industrial users of electricity to suppliers, regulators, and State and Federal Government bodies. Promotes dialogue on electricity management. Researches reasons for increasing electricity costs and possible ways to contain the increase. Holds workshops and seminars.

376 Electric Power Research Institute (EPRI)

Kurt E. Yeager, President and CEO

2312 Hillview Avenue

Palo Alto, CA 94303

Barbara Klein, Manager

Public Information

(415) 855-2413

Fax: (415) $855-2900$

Publications Distribution Center

(510) 934-4212

Fax: $(510) 944-0510$

One of America's oldest and largest private, nonprofit research organizations, EPRI's mission is to discover, develop high-value technological advances through networking and partnership with the electricity industry. EPRI's work covers a wide range of science and technology related to the generation, delivery, and use of electricity, with particular emphasis on cost-effectiveness and environmental quality. More than $350 \mathrm{EPRI}$ scientists and engineers manage some 1600 ongoing projects in collaboration with private industry, government laboratories, universities and other organizations worldwide.

\section{Energy Management Consortium (EMC)}

John Hoggard

Three Burlington Woods - 4th Floor

Burlington, MA 01803

(617) 273-0358

Fax: (617) 273-0360

A membership-based federation of professionals managing energy in commercial and institutional facilities nationwide which offers chapter meetings, energy planning assistance, free research, referral services, a personnel clearinghouse, an annual conference, newsletters, and energy management advocacy.

378 Florida Alliance for Clean Technologies 1889 N.W. 83rd Drive

Coral Springs, FL 33071

(954) 255-9324

Fax: $\{954) 255-9327$

Represents manufacturers, researchers, engineers and business professionals. The members develop, promote and advance clean technologies including, but not limited to, electric vehicles and electric transportation, clean (zero or low emitting) electric power generation and other environmentally beneficial technologies or fuels. Professionals provide end-to-end solutions for an entire inter-modal 
transportation arena which is responsive to an environmentally sound picture, utilizing team arrangements for the open exchange of ideas and expertise.

\section{Gas Appliance Manufacturers Association (GAMA)}

C. Reuben Autery, President

1901 North Moore Street, Suite 1100

Arlington, VA 22209

(703) $525-9565$

Members are manufacturers of residential, commercial, and industrial gas, oil, and electric appliances and equipment, including equipment used in the production, transmission, and distribution of fuel gases. Represents members before Federal and State legislative and regulatory bodies and consumer groups. Serves as a force for product improvement, a source of market statistics, and a means for product promotion and industrial publicity.

380

\author{
Gas Processors Association (GPA) \\ Mark F. Sutton, Executive Director \\ 6526 East 60th Street \\ Tulsa, OK 74145 \\ (918) 493-3872
}

Firms producing, processing, and handling natural gas liquids, and other hydrocarbon products (such as liquefied petroleum gases) at gas-processing plants. Develops technical standards and specifications for products; compiles basic data on hydrocarbon behavior, testing procedures, laboratory analysis, and plant safety practices. Cooperates with educational institutions on specific research projects; compiles statistics.

381 Gas Research Institute (GRI)

Stephen D. Ban, President and CEO

Headquarters

8600 West Bryn Mawr Avenue

Chicago, IL 60631-3562

(312) 399-8100

Fax: (312) $399-8170$

Washington Operations

1331 Pennsylvania Avenue, N.W.

Suite 730 North

Washington, DC 20004-1703

(202) $662-8989$

Fax: (202) 347-6925

GRI is the research, development and commercialization (RD\&C) organization for the natural gas industry. Its mission is to discover, develop and deploy technologies and information that measurably benefit gas customers and enhance the value of gas-energy services. The RD\&C program is structured around 10 business units; gas supply; residential; commercial; power generation; industrial; vehicles; gas distribution; transmission and storage systems; environment and safety; and basic research. Members include all major segments of the natural gas industry; producers, pipelines and distributors.

\section{Hearth Products Association (HPA) \\ Carter Keithley, President \\ 1601 North Kent Street, Suite 1001 \\ Arlington, VA 22209 \\ (703) 522-0086 \\ Fax: (703) 522-0548}

This national trade association was founded in 1980 when the Fireplace Institute and the Wood Energy Institute united to form the Wood Heating Alliance. In January 1992, the Alliance officially changed its name to the Hearth Products Association to better reflect the diversity within the industry and the range of products and services offered by its members. Under the direction of industry leaders, HPA is making important strides in promoting the safe use of wood, coal, and other alternative fuels and in protecting the hearth industry's livelihood.

\section{3}

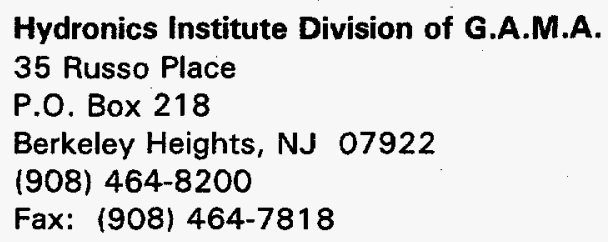

The Hydronics Institute is a non-profit organization, established to improve and promote the use of hydronic (steam and hot water) heating and allied cooling systems. In addition to an extensive literature list, including detailed design guides for all types of hydronic heating, the Institute publishes a yearly ratings manual of boilers and radiation equipment. A list of literature is available.

384 Illuminating Engineering Society of North America (IESNA)

William Hanley, Executive Vice President 121 Wall Street, 17th Floor

New York, NY 10005-4001

(212) $248-5000$

The IESNA was founded in 1906 to establish scientific lighting recommendations and to disseminate this information to all interested parties. It is the recognized authority on lighting in North America. Offers continuing education through section and regional meetings, technical conferences, and symposiums. Membership includes engineers, architects, designers, educators, students, contractors, distributors, utility personnel, scientists, physicians and manufacturers. Almost 10,000 individual members and 550 sustaining member 
companies comprise the membership of IESNA. It publishes the IESNA Handbook, standards, recommended practices, etc., in addition to its monthly magazine, Lighting Design and Applications, and its biannual journal.

\author{
385 Independent Electrical Contractors (IEC) \\ Dwight "Ike" Casey, Executive Vice \\ President \\ 507 Wythe Street \\ Alexandria, VA 22314 \\ (703) 549-7351
}

Members include independent electrical contractors, small and large, primarily open shop. Promotes the interests of members regardless of their labor affiliation; works to eliminate "unwise and unfair business practices" and to protect its members against "unfair or unjust taxes and legislative enactments." Sponsors electrical apprenticeship programs; conducts research and educational programs on estimating procedures, cost control, and personnel motivation. Represents independent electrical contractors to the National Electrical Code panel. Conducts surveys on volume of sales and purchases and on type of products used. Sponsors annual legislative workshop. Has formulated National Pattern Standards for Apprentice Training for Electricians.

\section{Independent Liquid Terminals Association (ILTA) \\ John Prokop, President \\ 1133 15th Street, N.W., Suite 650 \\ Washington, DC 20005 \\ (202) 659-2301}

International trade association which represents commercial operators of for-hire bulk liquids terminals and tank storage facilities located in North and South America, Europe, Asia, the United Kingdom, Australia, New Zealand and South Africa. These terminals interconnect with and provide services to the various modes of bulk liquid carriers, namely oceangoing tankers, tank barges, tank trucks, tank rail cars, and pipelines. The commodities handled include a variety of chemicals, crude oil, petroleum products, asphalt, animal fats and oils, vegetable oils, molasses, spirits, and fertilizers.

\section{Independent Lubricant Manufacturers Association (ILMA) \\ Richard H. Ekfelt, Executive Director \\ 651 South Washington Street \\ Alexandria, VA 22314 \\ (703) 684-5574}

Independent compounders and blenders of automotive, industrial, and metal working lubricants and greases. Associate members are base stock, additive, and packaging equipment suppliers. Conducts educational and regulatory compliance programs. Represents industry before Congress and Federal regulatory agencies and interacts with other industry groups. Compiles statistics; publishes monthly newspaper; maintains enforceable Code of Ethics.

\section{Independent Petroleum Association of America (IPAA) \\ Denise A. Bode, President 1101 16th Street, N.W. Washington, DC 20036 (202) 857-4722}

Members include independent oil and gas operators, royalty owners, and others (suppliers, drilling contractors, bankers, oil attorneys, trucking contractors, and rig building contractors) interested in the production of crude oil and natural gas. Represents small oil and natural gas producers in legislative and regulatory areas at the Federal level. Maintains speakers' bureau; compiles statistics.

\section{9}

\author{
Institute of Gas Technology (IGT) \\ Bernard S. Lee, President \\ 1700 S. Mt. Prospect Road \\ Chicago, IL 60018-1804 \\ (708) 768-0500 \\ Fax: (847) 768-0802
}

Nonprofit research and educational organization founded in 1941. Conducts contract research for Government and industry in environmental and nonnuclear energy technology. Members include companies engaged in the production, processing, transmission, and distribution of natural gas and related fuels, oil and coal producers, engineering firms, and large energy users. Areas of research specialization include molten carbonate fuel cells, the application of biotechnology to energy and environmental problems, improved utilization technology, the conversion of coal, oil shale, biomass, and waste to clean energy, natural gas distribution research, and natural gas vehicles. Offers short courses in gas production, distribution, economics, and marketing. Sponsors symposiums on current topics in non-nuclear energy. Maintains library of over 300,000 volumes.

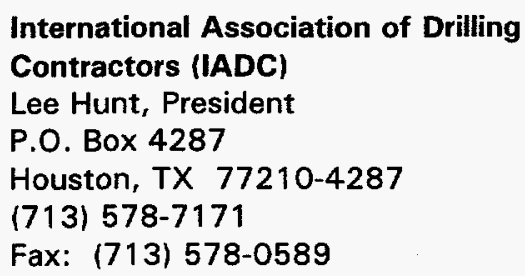

Membership comprises land and offshore drilling contractors, major and independent oil-and-gas 
producing companies, equipment manufacturers, oil field service and supply firms, and training facilities. Represents the global drilling industry before legislative and regulatory bodies at the State, Federal, and international levels. Compiles statistics on active rotary drilling rigs worldwide and on drilling safety. Publishes periodicals, reference books, training manuals, and forms. Conducts educational and professional meetings and seminars. There are 18 chapters worldwide, with headquarters in Houston, Texas, and other offices in Washington, DC, Aberdeen, and the Netherlands.

\section{Interstate Natural Gas Association of America (INGAA) \\ Jerald V. Halvorsen, President 555 13th Street, N.W., Suite 300-West Washington, DC 20004 (202) $626-3200$}

Trade association representing interstate natural gas pipelines in the United States and interprovincial pipelines in Canada. INGAA's members account for over 90 percent of the natural gas sold or transported in interstate commerce in the United States.

\section{National Association of Energy Service Companies (NAESCO) \\ Terry Singer, Executive Director \\ 1615 M Street, N.W. \\ Washington, DC 20036 \\ (202) 822-0952}

Members include individuals and firms providing energy efficiency services or electrical or thermal energy as an unregulated business activity by using a range of performance-based contracting and financing mechanisms, and nonprofit and Government bodies interested in the energy service industry. Purpose is to provide industry representation at all regulatory and government levels. Seeks to inform the public regarding performance contracting and financing of alternative energy and energy conservation programs. Promotes the development, growth, and status of the energy service industry. Serves as an information clearinghouse through bimonthly publication, Energy Efficiency Journal. Holds two major conferences yearly.

\section{National Association of State Utility Consumer Advocates (NASUCA) Charles A. Acquard, Executive Director 113315 th Street, N.W., Suite 550 Washington, DC 20005 (202) 727-3908}

NASUCA is a national organization comprised of 44 offices of ratepayer advocates in 38 States and the
District of Columbia who represents millions of American consumers served by investor-owned gas, telephone, electric, and water companies. NASUCA members are utility consumer advocate offices which operate independently from the regulatory commissions in their States. All are designated by State law to act as ratepayer advocates. The constituency, scope, and size of the member agencies vary. Some of the advocates are separately established utility advocate organizations, while others function as divisions or branches within larger State departments, such as the Office of Attorney General. Non-voting affiliate members of NASUCA serve utility consumers but these offices have not been created by State law nor do they have statewide authority.

394 National Electrical Contractors Association, Inc. (NECA)

John M. Grau, Executive Vice President

3 Bethesda Metro Center, \#1100

Bethesda, MD 20814

(301) 657-3110

Comprised of electrical contractors erecting, installing, repairing, servicing, and maintaining electric and telecommunications equipment, wiring, controls, and appliances. Provides labor relations and member services, including management development, marketing and sales support, research and education, codes and standards, government relations, and joint relations with suppliers of electric power and products. Also publishes monthly magazine, Electrical Contractor. There are approximately 4,000 member companies organized into 119 independent chapters nationwide.

\section{National Electrical Manufacturers \\ Association (NEMA) \\ Malcolm O'Hagan, President \\ 1300 N. 17th Street, Suite 847 \\ Rosslyn, VA 22209 \\ (703) $841-3200$}

Comprised of companies that manufacture equipment used for the generation, transmission, distribution, control, and utilization of electric power, such as electrical machinery, motors, wire and cable, and equipment for industrial automation, construction, medical diagnostic imaging, communication, and lighting. Objectives are to maintain and improve quality and reliability of products; to ensure safety standards in manufacture and use of products; to organize and act upon members' standards, testing, and certification issues, international trade energy conservation and efficiency, marketing opportunities, economic matters, and product liability. Develops product standards covering such matters as nomenclature, ratings, performance, testing, labeling and 
dimensions; participates in developing National Electrical Code and advocates its acceptance by State and local authorities; contributes to the development of American National Standards; conducts regulatory and legislative analyses on issues of concern to electrical manufacturers; complies and issues periodic summaries of statistical data on such factors as sales, new orders, unfilled orders, cancellation, production, and inventories.

\section{National Hydropower Association (NHA) Linda Church Ciocci 55513 th Street, N.W., Suite 900 East Washington, DC 20004 (202) $383-2530$}

Association of independent power producers, investor-owned utilities, public utilities, equipment manufacturers, developers, engineers, and attorneys involved in the hydroelectric industry. Represents the industry at all regulatory and governmental levels. Promotes pumped storage projects and development opportunities overseas. Dispenses information through a monthly newsletter and an annual conference.

\section{National Independent Energy Producers (NIEP) \\ Merribel S. Ayres, Chief Executive Officer 601 13th Street, N.W., Suite 320 S \\ Washington, DC 20005 \\ (202) 783-2244}

NIEP is an association of companies that supply electricity for sale to utilities. Its membership is comprised of both publicly-traded and privately-held corporations that develop and operate cogeneration and other wholesale generation facilities, as well as power marketers. NIEP members utilize a broad spectrum of fossil-fueled and renewable technologies, including hydro, biomass, pumped storage, geothermal, wood, waste coal and waste-toenergy plants, in addition to gas and coal-fired cogeneration and independent power production facilities.

398 National Institute for the Uniform Licensing of Power Engineers (NIULPE)

Larry Hamm, Executive Director

The Operators Building

P.O. Box 8753

Green Bay, WI 54308-8753

(800) 284-6084

Fax: (414) 435-5043

A nonprofit research and licensing organization founded in 1972 to provide uniform license examinations for engineers that operate plants and equipment. The NIULPE licenses insure that plant operators from Fourth Class Engineer to Chief
Engineer meet or exceed the requirements for safe and efficient operation of all types of commercial, utility and production plants. The State Boards of Examining Engineers provide regular examinations to operators. The NIULPE Standard is accepted by cities, states, the U.S. Army, the General Services Administration and the core curriculum was used by the Environmental Protection Agency to establish the requirements for the High-Capacity Fossil Fuel Operators Examination.

399 National Lubricating Grease Institute (NLGI)

Duane J. Fike, General Manager

4635 Wyandotte Street, Suite 202

Kansas City, MO 64112

(816) $931-9480$

Represents companies manufacturing or selling all types of lubricating greases; suppliers of such companies; technical/educational organizations; and consumers. Promotes research and testing for developing better lubricating greases, and provides avenues for lubrication technical services; collects and disseminates technical data; conducts forums and educational programs. Publishes a monthly journal, the NLGI Spokesman.

\section{National Mining Association (NCA) \\ Richard L. Lawson, President and CEO \\ 113017 th Street, N.W. \\ Washington, DC 20036 \\ (202) 463-2625}

The National Mining Association serves as the information center for the United States mining industry as well as the political presence for mining in Washington. The association works closely with Congress, the Executive Branch and Federal agencies to insure the establishment of constructive policies that will best enable the mining industry to serve the needs of the nation. The NMA's 400 members represent producers of most of America's coal, metals, industrial and agricultural minerals; manufacturers of mining and mineral processing machinery, equipment and supplies; transporters; financial and engineering firms; and other businesses related to coal and hardrock mining.

401 National Rural Electric Cooperative Association (NRECA)

Glenn English, Chief Executive Officer

4301 Wilson Boulevard

Arlington, VA 22203

(703) $907-5500$

Fax: (703) $907-5511$

National service organization representing rural electric cooperatives, public power districts, and public utility districts in 46 States. Activities include legislative representation; energy, regulatory and 
legal expertise; industry public relations; publication of a magazine and newsletter; management institutes; professional conferences; training and energy research and development consulting services; insurance and safety programs; women's and youth programs; wage and salary surveys; and an international program.

\section{Natural Gas Supply Association (NGSA) Nicholas J. Bush, President 805 15th Street, N.W., Suite 510 Washington, DC 20005 (202) 326-9300}

Represents companies that produce and market domestic natural gas. Established in 1965, NGSA encourages expanded use of natural gas and a regulatory climate that fosters steady supplies and competitive markets.

\section{North American Electric Reliability Council (NERC) \\ Michehl R. Gent, President \\ Princeton Forrestal Village \\ 116-390 Village Boulevard \\ Princeton, NJ 08540-5731 \\ (609) 452-8060 \\ Fax: (609) $452-9550$ \\ BBS: (609) 452-7669 \\ E-Mail: info@nerc.com \\ URL: http://www.nerc.com}

The mission of NERC is to promote the reliability of the electricity supply for North America. It does this by reviewing the past for lessons learned, monitoring the present for compliance with policies criteria, standards, principles, and guides, and assessing the future reliability of the bulk electric systems. It is a nonprofit corporation whose owners are nine regional councils. The members of these regional councils and one affiliate council come from all ownership segments of the electricity supply industry: investor-owned, state/municipal, provincial rural electric cooperative, and Federal utilities/state/municipal independent power producers, and power marketers. These entities account for virtually all the electricity supplied in the United States, Canada, and a portion of Baja California Norte, Mexico. NERC annually reviews the reliability and adequacy of the bulk electricity systems in North America, maintains several data bases (including the Generating Availability Data System), facilitates development of reliability-related planning and operating criteria and standards, and publishes related reports and reference documents.
404 Nuclear Energy Institute

Joe F. Colvin, President and CEO

1776 I Street, N.W., Suite 400

Washington, DC 20006

(202) $739-8075$

Consists of representatives from electric utilities, manufacturers, industrial firms, research and service organizations, educational institutions, labor groups, and Government agencies engaged in development and utilization of nuclear energy, especially nuclear-produced electricity, and other energy matters. Maintains speakers' bureau; compiles statistics and public attitude data; operates library of books, periodicals, government documents, and audiovisual material.

\section{Petroleum Marketers Association of America (PMAA) \\ Phillip R. Chisholm, Executive Vice President 1901 N. Ft. Myer Drive, Suite 1200 \\ Arlington, VA 22209 \\ (703) $351-8000$ \\ Fax: (703) 351-9160}

Federation of 44 State and regional petroleum marketing associations with approximately 10,000 independent petroleum marketers nationwide. Collectively, those marketers sell approximately 50 percent of the gasoline, 75 percent of the home heating oil, and 60 percent of the diesel fuel sold in this country each year.

Independent petroleum marketers are not "Big Oil." While they may obtain and sell their product under the brand name of a major oil company, they are generally not involved in production or refining.

The majority of independent petroleum marketers are small, often family-owned businesses.

\section{Potential Gas Committee \\ Potential Gas Agency \\ Colorado School of Mines \\ John B. Curtis, Director \\ Golden, CO 80401 \\ (303) $279-4320$}

Provides estimates of the potential supply of natural gas which, in conjunction with estimates of proved reserves of natural gas, make possible an appraisal of long-range supply. Comprised of volunteer members from the natural gas industry, government agencies, and academic institutions who are concerned with natural gas resources. Functions independently but with the guidance and assistance of the Potential Gas Agency of the Colorado School of Mines. 


\section{Service Station Dealers of America and Allied Trades (SSDA-AT) \\ Roy E. Littlefield, Executive Vice President 9420 Annapolis Road, Suite 311 \\ Lanham, MD 20706-3021 \\ (301) $577-4956$}

Service station operators who are members of affiliated State and local associations.

\section{United States Enrichment Corporation (USEC) \\ Barbara Arnold \\ 2 Democracy Center 6903 Rocklege Drive \\ Bethesda, MD 20817 \\ (301) $564-3200$ \\ Fax: (301) 564-3201}

A global energy company which provides uranium enrichment services to domestic and international utility customers. 



\section{INDEX}

A

AAMA, 343

AAR, 361

Abandoned Mine Land, 257

ABMA, 344

ACAA, 345

ACEC, 348

ACF, 346

Acoustics, 367

Advanced Hydrodynamic Facility, 17

AEE, 362

AGA, 350

Air, 82

Air Conditioning Contractors of America, 339

Air control, 367

Air Diffusion Council, 342

Air ducts standards, 342

Air Quality Planning and Standards, 277

Air Transport Association of America, 340

Aircraft owners, 341

Aircraft Owners and Pilots Association, 341

Airlines, 340

AISI, 351

ALA, 352

Alabama, 284

Alaska, 285

Alaska Power Administration, 236

Albuquerque Operations Office, 202

Alcohol fuels, 241, 357

Alternate fuels data, 107

Alternative fuel capabilities, 57

Alternative fuel vehicle technology, 58

American Architectural Manufacturers Association, 343

American Boiler Manufacturers Association, 344

American Coal Ash Association, 345

American Coal Foundation, 346

American College of Nuclear Physicians, 347

American Consulting Engineers Council, 348

American Council on Education, 349

American Gas Association, 350

American Home Lighting Institute, 352

American Iron and Steel Institute, 351

American Lighting Association, 352

American Nuclear Energy Council, 353

American Petroleum Institute, 354

American Public Power Association, 355

American Samoa, 286

American Society for Testing and Materials, 356

American Society of Agricultural Engineers, 357

American Statistical Association Committee on Energy Statistics, 6

American Underground Space Association, 358

American Wind Energy Association, 359

Ames Laboratory, 203

ANEC, 353

AOPA, 341
APA - The Engineered Wood Association, 360

API, 354

APPA, 355

Appliance efficiency standards, 62

Appliance energy guide labels, 62

Appliance manufacturers, 379

Appliances, 363

Arctic Environmental Data Directory, 258

Argonne National Laboratory, 204

Arizona, 287

Arkansas, 288

ASA, 6

Association of American Railroads, 361

Association of Energy Engineers, 362

Association of Home Appliance Manufacturers, 363

Association of Pellet Fuel Industries, 364

ASTM, 356

ATA, 340

ATF, 267

Atlanta Support Office, 64

Atomic bomb survivors, 94

Audiovisuals and Exhibits, 16

Automotive technologies, 56

AWEA, 359

\section{B}

Bartlesville Project Office, 205

Basic energy sciences, 137

Battelle Pacific Northwest National Laboratory, 206

BERA, 365

Bettis, 235

Biofuels production, 1

Biomass, 357

Biomass energy systems, 365

Biomass Energy Research Association, 365

Biomass power technologies, 47

Board of Contract Appeals, 165

Boiler manufacturers, 344

Boiler owners, 370

Bonneville Power Administration, 237

Boston Support Office, 64

Brick Institute of America, 366

Brick thermal properties, 366

Brookhaven National Laboratory, 207

Building energy efficiency, 59

Building energy sciences, 60

Building equipment, 61

Building systems, 60

Building technology, 59

Bulk liquids terminals, 386

Bureau of Alcohol, Tobacco, and Firearms, 267

Bureau of Census, 244

Bureau of Economic Analysis, 245

Bureau of Labor Statistics, 259 
C

California, 289

CAREIRS, 1

CECA/RF, 368

Ceilings and Interior Systems Construction Association, 367

Chemical sciences, 139

Chernobyl plant workers, 94

Chicago Operations Office, 208

Chicago Support Office, 64

CIBO, 370

Civilian radioactive waste management, 193

Coal and power systems, 154

Coal ash producers, 345

Coal data, 3, 107

Codes and Standards, 62

Cogeneration, 362

Cogeneration and Competitive Power Institute, 363

Colorado, 290

Commercial buildings energy information, 348

Communications, 9

Computational and technology research, 144

Congressional Affairs, 8

Congressional Liaison, DOE, 16

Connecticut, 291

Conservation and Renewable Energy Information and Referral Service, 1

Conservation projects education, 349

Conservation resources data, 3

Consumer Affairs, 16

Consumer Energy Council of America Research Foundation, 368

Consumer liaison, 8

Consumer Price Index, 259

Contract Disputes Act of 1978, 165

Contracting needs, 168

Contractor Employee Protection Programs, 158

Cooling Tower Institute, 369

Council of Industrial Boiler Owners, 370

Crude oil recovery, 4

Crude oil reserves, 106

CTI, 369

\section{D}

Dams, DOE, 76

Data collection forms, 3

Data Resources Directory, 115

Data survey forms, 3

DCIE, 371

Defense Department, 252

Defense Fuel Supply Center, 292

Defense Programs, DOE, 17

Delaware, 292

Denver Support Office, 64

Department of Energy publications, 5

Department of Health and Human Services, 253

Department of Housing and Urban Development, 254
Department of Labor, 259

Department of Transportation, 262

Department of Treasury, 267

Direct Current Electricity Institute, 371

Diskettes, 3

District of Columbia, 293

DOE reports, 5 .

DOE research projects, 5

DOE This Month, 16

Drilling industry, 390

Drilling technology, 4

Driver's licenses issued, 264

Dual Axis Radiological Hydrodynamic Test Facility, 17

E

Earth Science Data, 258

Earthquakes, 258

Economic Research Service, 241

Edison Electric Institute, 372

EEI, 372

EGSA, 373

EIA, 102

EIA press releases, 3

EIS, 278

ELCON, 375

Electric Generation Association, 374

Electric power data, 3

Electric Power Research Institute, 376

Electric transportation, 378

Electric utilities representative, 355

Electric utility companies, 372

Electric vehicles, 378

Electrical contractors, 385, 394

Electrical Generating Systems Association, 373

Electrical power generating devices, 373

Electricity Consumers Resource Council, 375

Electricity data, 107

Electricity sales, 397

Electrochemistry, 49

EMC, 377

Emissions data, 277

EML, 209

Employment statistics, 260

End use and integrated statistics, 112

Energy biosciences, 141

Energy consumption trends, 110

Energy efficiency, 1, 43

Energy efficiency planning, 59

Energy efficiency services, 392

Energy Efficiency and Renewable Energy

Clearinghouse, 1

Energy efficient appliances, 1

Energy Information Administration, 102

Energy Management Consortium, 377

Energy markets and contingency information, 111

Energy markets and end use, 110

Energy performance standards, 62

Energy policy, 179 
Energy research, 135

Energy Science and Technology Software Center, 2

Energy Services Marketing Society, 362

Energy Technology Visuals Collection, 170

Engineering and geosciences, 140

Enhanced oil recovery, 4

Environment, safety and health, 68

Environment, safety and health evaluations, 71

Environment, safety and health technical support, 136

Environmental Engineers and Managers Institute, 362

Environmental Impact Statements, 278

Environmental management, 119

Environmental Measurements Laboratory, 209

Environmental Protection Agency, 276

Environmental restoration, 127

Environmental sciences, 152

Epidemiologic studies, 93

EPRI, 376

EREC, 1

ESTSC, 2

ETVC, 170

\section{$\mathbf{F}$}

Federal buildings, 59

Federal energy management programs, 66

Federal Energy Regulatory Commission, 199

Federal Highway Administration, 264

Federal Research in Progress, 251

Federal Taxpayers Service Line, 268

FedWorld, 251

FERC, 199

Fermi National Accelerator Laboratory, 210

FIND, 281

Fireplace Institute, 382

Fleet Test Operations, 58

Florida, 294

Florida Alliance for Clean Technologies, 378

Forest biomass research, 242

Forest Industry Data System, 281

Forest Service, 242

Fossil energy, 153

Freedom of Information and Privacy Act, 169

Fuels development, 55

Fusion base technology development program, 147

Fusion energy sciences, 145

Fusion research experiments, 148

$\mathbf{G}$

GAMA, 379

GAO, 282

Gas Appliance Manufacturers Association, 379

Gas processing plants, 380

Gas Processors Association, 380

Gas Research Institute, 381

General Accounting Office, 282

Geographic information system, 258
Geologic maps, 258

Georgia, 295

Geothermal technologies, 46

German uranium miners, 94

Golden Field Office, 67

Government Printing Office, 283

GPA, 380

GPO, 283

Grain-based fuel alcohol, 241

Grand Junction Projects Office, 211

Graphics, 170

Greases, 387

Greenhouse gas emissions, 116

Greenhouse gases, 54

GRI, 381

Guam, 296

H

Hanford Environmental Health Foundation, 212

Hanford Operations, 126

Hawaii, 297

Hazardous waste management ${ }_{r} 230$

Hazardous waste materials, 119

Health and environmental research, 149

Health effects and life sciences research, 150

Hearings and Appeals, 158

Hearth industry, 382

Hearth Products Association, 382

Heat pump applications, 339

Heat transfer, 49

Heavy vehicle technologies, 57

High energy and nuclear physics, 142

Highway use of motor fuels, 264

Hot water heating, 383

House Liaison, DOE, 10

House of Representatives Committee on Commerce, 274

House of Representatives Subcommittee on Energy and Power, 275

HPA, 382

HUD, 254

HUD USER， 255

Human radiation experiments, 100

Hydroelectric industry, 396

Hydrogen technologies, 47

Hydronics Institute Division of G.A.M.A., 383

I

IADC, 390

Idaho, 298

Idaho Operations Office, 213

IEC, 385

IESNA, 384

IGT, 389

Illinois, 299

Illuminating Engineering Society of North America, 384

ILMA, 387 
ILTA, 386

Import Administration, 246

Independent Electrical Contractors, 385

Independent Liquid Terminals Association, 386

Independent Lubricant Manufacturers Association, 387

Independent Petroleum Association of America, 388

Independent power generation, 1

Independent power producers, 396

Indiana, 300

Indoor Air Quality Information Clearinghouse, 276

Industrial technologies, 49

Industries of the Future, 51

Inertial Fusion and Ignition Facility Project, 22

INGAA, 391

Institute of Gas Technology, 389

Integrated analysis and forecasting, 116

Intergovernmental Affairs, 8

Intergovernmental and External Affairs, 15

Interior insulation systems, 367

Interior lighting, 367

Internal Revenue Service, 268

International affairs, 179

International Association of Drilling Contractors, 390

International health programs, 94

International nuclear energy, 171

International Nuclear Safety, 174

International Thermonuclear Experimental Reactor, 147

International Trade Administration, 247

International Trade Commission, 279

Interstate Natural Gas Association of America, 391

Inventions, 249

lonizing radiation, 91

lowa, 301

IPAA, 388

Isotope production and distribution, 178

ITER, 147

\section{$J$}

Joint Venture/International and Tribal Government Programs, 48

\section{$\mathbf{K}$}

Kaiser Engineers Hanford Company, 214

Kansas, 302

Kentucky, 303

Knolls Atomic Power Laboratory, 233

\section{$\mathbf{L}$}

Lawrence Berkeley National Laboratory, 215

Lawrence Livermore National Laboratory, 18, 216

Leasable minerals, 256

Legislative policies, 10

Legislative research, 8

Light Water Reactor Production, 40

Lighting Design and Applications, 384
Lighting efficiency, 352

LIHEAP, 253

Liquid fossil fuel technology, 4

Locomotive fuels, 361

Los Alamos National Laboratory, 18, 217

Louisiana, 304

Low Income Home Energy Assistance Program, 253

Lubricants, 387

Lubricating greases, 399

M

Machine-readable files, 3

Machine-readable modeling tapes, 3

Magnetic fusion energy, 229

Maine, 305

Manhattan Project, 203

Maps, 258

Maryland, 306

Massachusetts, 307

Material sciences, 138

Media/Press inquiries, 3

Medical applications and biophysical research, 151

Merchandise trade, 244

METC, 218

Michigan, 308

Mileage of roads and streets, 264

Mine Safety and Health Administration, 261

Minerals Management Service, 256

Mining industry, 400

Mining machinery, 246

Minnesota, 309

Minority Economic Impact Office, 41

Mississippi, 310

Missouri, 311

Montana, 312

Morgantown Energy Technology Center, 218

MSHA, 261

\section{$\mathbf{N}$}

NAESCO, 392

NASUCA, 393

NATAS, 1

National Appropriate Technology Assistance Service, 1

National Association of Energy Service Companies, 392

National Association of State Utility Consumer Advocates, 393

National Climatic Data Center, 250

National Electrical Contractors Association, Inc., 394

National Electrical Manufacturers Association, 395

National Energy Information Center, 3

National Energy Modeling System, 116

National Environmental Policy Act, 33, 79

National Highway Traffic Safety Administration, 265

National Hydropower Association, 396

National Ignition Facility, 17 
National Independent Energy Producers, 397

National Industrial Competitiveness Through Energy Environment and Economics, 53

National Institute for Petroleum and Energy Research, 4

National Institute for the Uniform Licensing of Power Engineers, 398

National Institute of Standards and Technology, 249

National Lubricating Grease Institute, 399

National Mining Association, 400

National Oceanic and Atmospheric Administration, 250

National Renewable Energy Laboratory, 67, 219

National Rural Electric Cooperative Association, 401

National Science and Technology Council, 19

National security, 182

National Technical Information Service, 251

Nationwide Personal Transportation Survey, 264

Natural gas and oil statistical data, 103

Natural gas data, 3

Natural gas distribution, 389

Natural gas industry, 381

Natural gas liquids, 380

Natural gas pipelines, 391

Natural gas processing, 389

Natural gas reserves, 106

Natural gas technologies, 155

Natural gas transmission, 350, 389

Natural Gas Supply Association, 402

Naval Nuclear Propulsion Program, 233, 235

Naval petroleum reserves, 157

Naval Petroleum and Oil Shale Reserves in Colorado, Utah, and Wyoming, 220

Naval reactors, 177

Naval Reactors Facility, 235

Naval petroleum reserves in California, 221

NCA, 400

Nebraska, 313

NECA, 394

NEIC, 3

NEMA, 395

NEMS, 116

NEPA, 33, 84

NERC, 403

Nevada, 314

Nevada Operations Office, 222

Nevada Test Site, 18

New Hampshire, 315

New Jersey, 316

New Mexico, 317

New York, 318

News clips, 14

NGSA, 402

NHA, 396

$\mathrm{NICE}^{3}, 53$

NIEP, 397

NIPER, 4

NIULPE, 398

NLGI, 399

NLG/ Spokesman, 399
NOAA, 250

North American Electric Reliability Council, 403

North Carolina, 319

North Dakota, 320

NRECA, 401

NREL, 219

NTIS, 251

Nuclear and facility safety, 74

Nuclear and radiological emergencies, 27

Nuclear energy data, 3, 107

Nuclear Energy Agency, 2

Nuclear Energy Institute, 404

Nuclear issues, 171

Nuclear medicine, 347

Nuclear physicians, 347

Nuclear power plant licensing, 280

Nuclear Regulatory Commission, 280

Nuclear safety, 69

Nuclear safety enforcement, 101

Nuclear safety policy and standards, 75

Nuclear testing, 222

Nuclear weapons research, 17

Nuclear Weapons Management, 26

Nuclear Weapons Stockpile, 23

0

Oak Ridge National Laboratory, 224

Oak Ridge Operations Office, 225

Oakland Operations Office, 223

Occupational medicine and medical surveillance, 92

Occupational safety and health policy, 88

OCs, 256

Office of Scientific and Technical Information, 5

Offshore drilling contractors, 390

Offshore leasing program, 256

Ohio, 321

Oil and gas operators, 388

Oil and gas statistical data, 103

Oil field service, 390

Oil shale, 4

Oil shale reserves, 157

Oklahoma, 322

On-shore drilling contractors, 390

Oregon, 323

Organization for Economic Cooperation and

OSTI, 5 Development, 2

Outer Continental Shelf, 256

Overcharge funds, 158

$\mathbf{P}$

Pacific Northwest National Laboratory, 206

Pantex Plant, 28

Passive solar building technologies, 60

Pellet appliance manufacturers, 364

Pennsylvania, 324

Petroleum data, 3

Petroleum extraction, 4 
Petroleum industry representative, 354

Petroleum marketers, 405

Petroleum Marketers Association of America, 405

Petroleum marketing, 105

Petroleum supply, 104

Petroleum technologies, 155

Philadelphia Support Office, 64

Photovoltaic technologies, 45

Pittsburgh Energy Technology Center, 226

Pittsburgh Naval Reactors Office, 227

PMAA, 405

PNNL, 206

Portsmouth Site Office, 228

Potential Gas Committee, 406

PPPL, 229

Press and media services, 8

Press Office, 16

Press relations, 9

Press Secretary, 13

Price-Anderson Amendments Act of 1988, 101

Princeton Plasma Physics Laboratory, 229

Printing, 179

Procurement and assistance management, 166

Procurement operations, 168

Public Affairs, 8

Public information activities, 8

Puerto Rico, 325

Quality assurance, 114

\section{$\mathbf{R}$}

Radiation, 82

Radiation research, 231

Radioactive waste management, 193

Railroads, 361

RCRA/CERCLA, 83

Recycling waste lubricating oil, 4

Renewable energy, 43

Renewable energy education, 349

Renewable energy research, 67

Renewable energy resources data, 3

Renewable energy technologies, 1

Research in progress, 5

Rhode Island, 326

Richland Operations Office, 230

Rig building contractors, 388

Royalty owners, 388

Rural electric cooperatives, 401

Rural Utilities Service, 243

\section{$\mathbf{S}$}

Sandia National Laboratories, 18, 231

Savannah River Operations Office, 232

Savannah River tritium facilities, 28

Schenectady Naval Reactors Office, 233

Science and technology, 171
Scientific Technical Engineering Information, 251

SEAB, 7

Seattle Support Office, 64

Secretary of Energy Advisory Board, 7

Senate Committee on Energy and Natural Resources, 270

Senate Liaison, DOE, 10

Senate Subcommittee on Energy Research and Development, 271

Senate Subcommittee on Public Lands, National Parks, and Forests, 272

Senate Subcommittee on Water and Power, 273

Service Station Dealers of America and Allied Trades, 407

Skylights, 343

Small and Disadvantaged Business Utilization Office, 42

SNR, 233

Software catalog, 2

Software Center, 2

Solar energy, 357

Solar thermal technologies, 47

Sound absorption, 367

South Carolina, 327

South Dakota, 328

Southeastern Power Administration, 238

Southwestern Power Administration, 239

Speakers' Bureau, 16

SSDA-AT, 407

Stanford Linear Accelerator Center, 234

State and community programs, 63

Statistical and analytical energy data, 3

Statistical standards, 113

Steam heating, 383

Steel industry, 351

Storm windows, 343

Strategic Petroleum Reserve, 156

Surface Mining Reclamation and Enforcement, 257

Survey management, 108

$\mathbf{T}$

Tank storage facilities, 386

Tar sands, 4

Tennessee, 329

Tennessee Valley Authority, 281

Testing Facilities, 18

Texas, 330

Thermodynamics, 49

Transportation technologies, 54

Tribal governments, 15

Tritium Project Office, 38

Trucking contractors, 388

\section{$\mathbf{U}$}

U.S. Geological Survey, 258

Underground space, 358

United States Enrichment Corporation, 408

Uranium enrichment production, 228 
Uranium enrichment services, 408

Uranium suppliers, 353

USEC, 408

USGS, 258

Utah, 331

Utility consumer advocates, 393

Utility technologies, 44

V

Vegetable oil fuels, 357

Vehicle registration data, 264

Vehicle-miles traveled, 264

Vermont, 332

Virgin Islands, 334

Virginia, 333

Volcanoes, 258

W

Washington, 335

Waste acceptance, 198

Waste management program, 120

Waste storage, 198

Waste transportation, 198

Water, 82

Water conservation, 369

Weather charts, 250

West Virginia, 336

Western Area Power Administration, 240

Western tight sands, 4

Westinghouse Electric Corporation, 235

Wind energy, 357

Wind energy industry, 359

Wind technologies, 45

Window films, 343

Windows, 343

Wisconsin, 337

Wood, 382

Wood Energy Institute, 382

Wood Heating Alliance, 382

Wood insulating properties, 360

Wood residue, 281

Woody biomass, 242

Worker health and safety, 87

Worker protection programs, 89

Wyoming, 338

$\mathbf{Y}$

Y-12 Plant, 28

Yucca Mountain Site Characterization Office, 196 